(3.

(1)

$4 \times-x_{0}$

\%

4 $\%$ \%

-
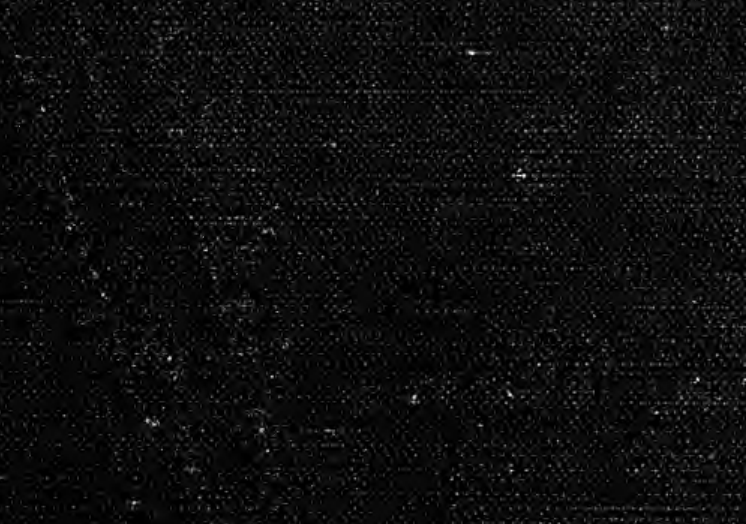

* 1

6.25 


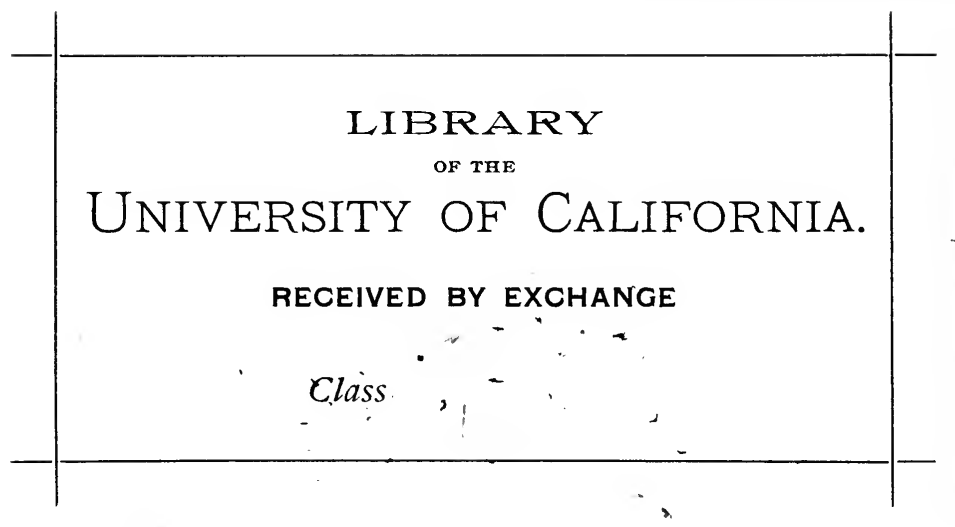








\title{
OHIO POLITICS DURING THE CIVIL WAR PERIOD
}

\author{
BY \\ GEORGE H. PORTER, Ph.B., \\ Sometime Fellow in American History, Columbia University
}

SUBMITTED IN PARTIAL FULFILMENT OF THE REQUIREMENTS FOR THE DEGREE OF DOCTOR OF PHILOSOPHY

IN THE

Faculty of Political Science

Columbia University

NEW YORK

I 9 I I 



\section{PREFACE}

AN attempt has been made in the following pages to set forth the attitude of Ohio on the great political questions of the civil war period. Issues purely local and having nothing to do with the war have been omitted. The important rôle which the state played in national affairs during this period through the prominence of her political leaders has seemed to make such a study well worth while.

Much use has necessarily been made of the newspapers. Owing to the personality of many of their editors, they reflected the opinion of the various political factions to a marked degree. While newspaper accounts are not always to be relied upon, they have been carefully sifted and fortified by information derived from other sources.

The material for a study of the war period exists in a somewhat fragmentary condition. Many local newspapers have not been preserved, while a number of public reports and other documents have either been destroyed or are not accessible to the student. There is great need of a Public Archives Commission to undertake the work of preserving and arranging the historical material of the state.

During the progress of my research, I have been greatly assisted by many persons who have manifested an interest in the subject. Mr. C. B. Galbreath, of the Ohio State Library, has rendered invaluable service both in aiding me to secure material and in making suggestions on the treatment of various topics. I am also greatly indebted to $\mathrm{Mr}$. Daniel J. Ryan for permission to use the proof-sheets of his Civil War Literature of Ohio; to Col. Webb C. Hayes for I4I ] 
permission to examine his father's papers; to $\mathrm{Mr}$. W. H. Cathcart for the use of material in the library of the Western Reserve Historical Society; to Mr. A. D. Wilt and Mrs. W. D. Bickham, of Dayton, for assistance in obtaining material and for permission to use some unpublished letters; to Minnie E. Porter for a critical reading of the manuscript; and to Mr. C. N. Vallandigham, of Boston, for copies of unpublished letters of C. L. Vallandigham.

The study was undertaken at the suggestion of Professor W. A. Dunning, of Columbia University. To him my thanks are due for many suggestions made during the progress of the work and for assistance in preparing the manuscript for the press.

New York City, April 24, I9II.

George H. Porter. 


\title{
CONTENTS
}

\author{
CHAPTER I \\ Ohio Politics at the Opening of the War
}

Review of Political Affairs Prior to 1859 . . . . . . . . . . I2

Wealth and population of the state........... I2

Influence of population elements on politics . . . . . . I6

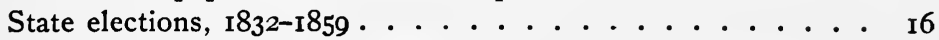

Legislation on the negro, $1802-1855 . . . . . . . . \quad$ I9

Personal Liberty laws ............... 2I

Repeal of Personal Liberty laws. . . . . . . . . . 22

Enactment of "Visible Admixture law" ......... 22

Interpretation of the word "white" by supreme court . . . 22

Relations with the Border States During 1859-1860 . . . . . 23

The Oberlin-Wellington rescue case. . . . . . . . 23

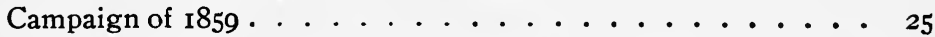

Analysis of the legislature elected in 1859 ........ 26

The John Brown raid . . . . . . . . . . . . 27

Election of a U. S. Senator in I860 . . . . . . . . 30

Visit of Kentucky and Tennessee legislatures ........ 3I

Attempts to reënact Personal Liberty laws, 1860. . . . . . 32

Attempts of the Democrats to restrict negro immigration . . . 34

Legislature on the John.Brown raid . . . . . . . . 35

Extradition of Brown and Merriam . . . . . . . 38

The Lago case . . . . . . . . . . . . . . 40

The Kennedy case ............... . 4I

Party Conventions and the Campaign of 1860 . . . . . . . . . 42

Democratic convention, January 5, 1860 . . . . . . . 42

Republican convention, March Ist. . . . . . . . . 43

Republican nominating convention, June 13 th . . . . . . 44

Democratic convention, July 4 th . . . . . . . . 44

Breckinridge revolt ............. 45

Constitutional Unionists ............. . 46

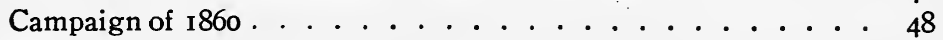

Election .................... 48

143] 
Attitude of Ohio on Secession and Compromise PAG

49

Opinions in the North on secession .......... 49

Opinions in Ohio on secession ............ . 50

Democratic convention, January 23, 1860 . . . . . . 52

Legislature on questions of compromise . . . . . . . . 55

Resolutions of January rath . . . . . . . . . . . 58

Question of unconstitutional legislation . . . . . . . . 6I

The extradition question in the legislature . . . . . . . . 62

Selection of delegates to the Peace Conference . . . . . . . 64

Question of calling a national convention .......... 68

Attempt at ratifying proposals of Peace Conference. . . . . . 68

The extradition question again. . . . . . . . . . . 69

Request for Ohio to guarantee U. S. bonds . . . . . . . . 70

Election of Sherman to U. S. Senate . . . . . . . . . 70

Growth of the spirit of compromise in the state ...... . 7I

\section{CHAPTER II}

\section{The Union Party in Ohio: Organization and Work}

Genesis of the Union Party . . . . . . . . . . . . . . . . 73

Enthusiasm at the outbreak of the war. . . . . . . . 73

Change of sentiment . . . . . . . . . . . . 74

Abandonment of party feeling . . . . . . . . . 74

The million-dollar appropriation. . . . . . . . . . . 75

Protection of southern border of the state . . . . . . 76

Other acts of the legislature for support of the war . . . . . 77

Difficulties in the way of union movement. . . . . . . 78

Call for Democratic state convention . . . . . . . . . . 79

Plans for union movement . . . . . . . . . . . . . . 80

Resolution of Republican state central committee . . . . . 8I

Democratic sentiment on union movement. . . . . . . 8I

Attitude of the Abolition element . . . . . . . . 82

Democratic state convention, August 7, 1861. . . . . . . 83

Jewett's letter of acceptance. . . . . . . . . . . . . 84

Call for Union mass convention . . . . . . . . . . 86

Question of platform and candidate . . . . . . . . . 87

The Union convention, September 5, 186r. . . . . . . . 88

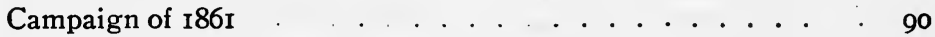

Election . . . . . . . . . . . . . . . 90

Work of the First Union Legislature . . . . . . . . . . . . . . 9I

Governor Tod's inaugural. . . . . . . . . . . . . . 92

Lack of harmony among the Union members . . . . . . 93

Retrenchment ............... 95 
Reapportionment of state for congressional purposes . . . . . 96

Question of immigration of the negro . . . . . . . . . 96

Attempt to elect a U. S. Senator . . . . . . . . . . . . . 98

The Political Campaign of 1862 . . . . . . . . . . . . . . . . . 100

Desire to revive the old party . . . . . . . . . . . . 100

Union state convention, August 21st . . . . . . . . . . 102

The Democratic ticket . . . . . . . . . . . . . 102

Issues in the campaign . . . . . . . . . . . . . . 104

Election . . . . . . . . . . . . . 108

Effect of the defeat on the Union party . . . . . . . . 108

Efforts to Strengthen the Party after the Defeat of 1862 . . . . . 109

Meeting of the legislature, I863........... I Io

Message of Governor Tod. . . . . . . . . . . . . IIO

The Senatorial question . . . . . . . . . . . . . . . III

No legislative expression on Emancipation Proclamation . . . . 112

Soldiers' voting law. . . . . . . . . . . . . . . II3

Resignation of state auditor Taylor. . . . . . . . . . . II3

Low tide of the Union party. . . . . . . . II5

Resolutions of Ohio regiments . . . . . . . . . . . II5

Organization of Union Leagues . . . . . . . . . . I16

Question of a Union candidate in 1863 . . . . . . . . 117

The Brough boom . . . . . . . . . . . . II9

Union state convention . . . . . . . . . . . . . . I 20

The Union Party in the Campaign of 1864 . . . . . . . . . . . . I2I

Result of the election of 1863 . . . . . . . . . . . 122

Rescinding of ratification of Corwin Amendment. . . . . . . . 122

Action of the legislature on a Presidential candidate . . . . I22

Ohio in the Baltimore convention. . . . . . . . . 125

Campaign of $1864 . \quad$. . . . . . . . . . . . . ${ }_{125}$

Union party continued after the war . . . . . . . . . I26

\section{CHAPTER III}

\section{Vallandigham and the Peace Democracy}

The Peace Democracy During the Early Part of the War. . . . . 128

The Peace Democrats defined . . . . . . . . . . . I28

Vallandigham as leader in the West . . . . . . . . . I28

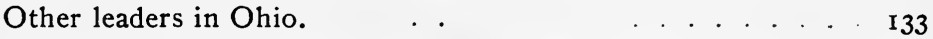

Attitude of Democratic leaders toward the Union movement . 134

Revival of the party after the election of $\mathrm{I} 86 \mathrm{I}$. . . . . . . I 136

Ohio Democrats in Congrees, I86I-I862 . . . . . . . . . 137

Effect of the Democratic Address on Ohio politics . . . . . . 138

Democratic state convention, July 4, I862 . . . . . . . . . I39

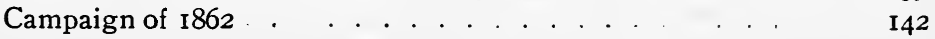


Effect of the Election of 1862 on the Peace Democracy. PAGE

Jollification meetings . . . . . . . . . . . . . . . . . . . . 144

Ohio Democrats in Congress, $1862-1863$. . . . . . . . . I45

Vallandigham's speech, January I4, I863 . . . . . . . I47

Disposition of the Peace Democrats in Ohio . . . . . . . . 148

Olds escorted to Columbus . . . . . . . . . . . . . . . I49

Jackson Day banquet, January 8, I863 . . . . . . . . . I 49

Attitude of the Democrats in the legislature . . . . . . . I50

Dresel resolutions on military arrests . . . . . . . . . I5I

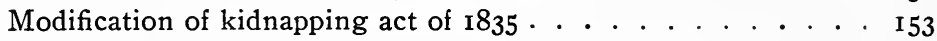

Attempt to expel Dresel . . . . . . . . . . . . . . I54

Democratic agitation against negro immigration. . . . . . I55-

Democratic meetings during spring of $1863 \ldots . . . . .255$

Mobbing of Crisis office ............... . ${ }_{156}$

Arrest of Governor Tod. . . . . . . . . . . . . . I57

Arrest and Trial of Vallandigham . . . . . . . . . . . . I59

Assignment of General Burnside to Department of Ohio . . . . I59

General Order Number 38 . . . . . . . . . . I60

The Mount Vernon meeting . . . . . . . . . . . I6I

Arrest of Vallandigham . . . . . . . . . . . . . . I62

Trial before a military commission . . . . . . . . . I62

Application for writ of habeas corpus . . . . . . . . . I62

Finding of the commission . . . . . . . . . . . . . . I65

General opinion of the arrest . . . . . . . . . . . I65

The Campaign of 1863 . . . . . . . . . . . . . . . . . 167

Effect of the arrest of Vallandigham. . . . . . . . . . . I67

Protest of the New York Democrats. . . . . . . . . . . . . . 168

The Democratic state convention, June IIth . . . . . . . . I70

The state-sovereignty faction . . . . . . . . . . . I73

Lincoln and the Ohio committee . . . . . . . . . . I74

Arrival of Vallandigham in Canada . . . . . . . . . . . . I77

The campaign . . . . . . . . . . . . . . . . . . . I78

Convention of War Democrats . . . . . . . . . I8I

Election . . . . . . . . . . . . . . . . 183

Democratic press on causes of defeat. . . . . . . . . I84

Effect of the defeat on Vallandigham ........... I85

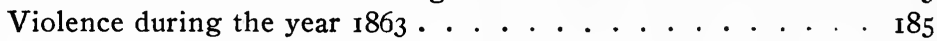

Activity ot the Knights of the Golden Circle. . . . . . . . I87

The dime fund . . . . . . . . . . . . . . . . . 188

New church movement. . . . . . . . . . . . I89

The Democracy in the Campaign of 1864. . . . . . . . . . . . . I90

Condition of the Democracy at the beginning of 1864. . . . . Igo

Attacks on Democratic newspaper offices . . . . . . . IgI 
Democratic state convention of 1864 .

Return of Vallandigham. . . . . . . . . . . . . . . . . . I94

Campaign of 1864. . . . . . . . . . . . . . . . . . . . 196

Convention of state-rights Democrats . . . . . . . . . 197

The Democracy during reconstruction . . . . . . . . . . . . I98

Conclusion . . . . . . . . . . . . . . . . . 198

\section{CHAPTER IV}

\section{The Question of Negro Suffrage in Ohio}

Politics of the Year 1865 . . . . . . . . . . . . . . . 200

Sentiment on negro suffrage at the opening of the war. . . . 20I

Ratification of the Thirteenth Amendment. . . . . . . . 202

Repeal of "Visible Admixture law" . . . . . . . . . 202

Support of President Johnson . . . . . . . . . . . . . . 203

Attitude of the Democracy toward Johnson . . . . . . . 203

Call for Union state convention. . . . . . . . . . . . . 204

Question of suitable Union candidate for governor . . . . . . 205

Union state convention, June 2rst . . . . . . . . . . 206

Nomination of General Cox . . . . . . . . . . . 207

Compromise platform adopted . . . . . . . . . . . 207

General Cox's Oberlin letter ............ 210

Reply of Judge Dickson. . . . . . . . . . . . . . . 2 I I

John Stuart Mill's opinion on negro suffrage sought . . . . 212

General Sherman boomed by the Democrats for governor . . . 213

Convention of state-sovereignty Democrats, August I7th . . . 214

Democratic state convention, August 24th . . . . . . . 214

General Morgan nominated . . . . . . . . . . . . 215

Campaign of 1865. . . . . . . . . . . . . . 216

Election .. . . . . . . . . . . . . . . . . . 219

Negro suffrage postponed by legislature . . . . . . . . 219

Election of U. S. Senator . . . . . . . . . . . . . . . . . 220

Attitude of Ohio Toward the Quarrel Between President Johnson and Congress. . . . . . . . . . . . . . . . . . 220

Congressional legislation, I865-1866........... 22I

Legislature holds aloof from quarrel on reconstruction .... 221

Governor Cox's "Johnson letter" . . . . . . . . . . . . 222

Democratiç state convention, May 24, I866 . . . . . . . 223

Union state convention, June 20, 1866. . . . . . . . . 226

Endorsement of the congressional policy. . . . . . . . 226

Call for national Union convention . . . . . . . . . . . . 227

Response of Johnson Unionists . . . . . . . . . . . 227

Response of the Democrats ............ 228 
Vallandigham left off the list of delegates . . . . . . . . 229

The Johnson state convention, August 7th . . . . . . 230

Ohio in the Philadelphia convention, September 3d . . . 23I

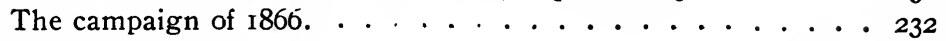

Election . . . . . . . . . . . . . . 234

Negro Suffrage Defeated . . . . . . . . . . . . 235

Ratification of Fourteenth Amendment ......... 235

Negro suffrage amendment proposed by the legislature . . . 236

Democratic state convention, January 8, 1897 . . . . 238

Activity of the state-sovereignty Democracy . . . . . . . 240

Difficulty of securing a suitable Union candidate. . . . . . 240

The Union state convention, June Igth . . . . . . . 242

The "Ohio Deserters' bill" . . . . . . . . . . . . . 243

The campaign of 1867 . . . . . . . . . . . . . 243

Election . . . . . . . . . . . . . . . . 248

Defeat of negro suffrage amendment. . . . . . . . . 248

Rescinding of ratification of Fourteenth Amendment . . . . 248

Reënactment of "Visible Admixture law" . . . . . . . 25I

Election of Thurman as U. S. Senator. . . . . . . . . 253

Rejection of Fifteenth Amendment . . . . . . . . . 253

Ratification of Fifteenth Amendment . . . . . . . . 254

Bibliographical Note . . . . . . . . . . . . . . . . 255 


\section{CHAPTER I}

\section{Ohio Politics at the Opening of the War}

REVIEW OF POLITICAL AFFAIRS PRIOR TO I859

At the opening of the period covered by this study Ohio occupied an important position in national affairs both industrially and politically. The state was situated midway between the agricultural West and the manufacturing East and thus formed a debatable ground between the political tendencies of these two sections, while as the gateway leading from the South to the Northwest her commercial relations with the South through Cincinnati were such as to identify her interests with those of the border states. Her state elections assumed national importance from the fact that they were held in October, just a month before the presidential contests, and because a governor was chosen in the year preceding the national elections. This made the state a sort of "political weather-gauge" and led the two great political parties to concentrate their efforts upon the Ohio elections to an unusual degree.

In wealth and population the state ranked third in 1860. The value of her real estate and personal property amounted to over a billion and a half dollars. ${ }^{1} \quad$ Notwithstanding the financial depression of 1857 , the taxable property doubled in value during the decade ending in 1860, and on the basis of this valuation taxes for state and local purposes amounting to almost eleven million dollars were levied for the year I86r. This wealth arose for the most part from agriculture, manufacturing being then in its infancy.

The population increased from $1,980,960$ in 1850 to

${ }^{1}$ Report of the Ohio Commissioner of Statistics, 1860. I49] 
$2,339,5$ I I in I860. It was largely rural, only one-ninth of the whole number of people living in cities. Fourteen per cent of the inhabitants were foreign born, the German element largely predominating. ${ }^{1}$ In forty-six counties over ten per cent of the population was foreign, while in eleven -for the most part those containing the larger cities-this was increased to twenty per cent. Internal migration also had a noticeable effect on the population. I,529,560 persons who were residing in the state in 1860 had been born within its borders. 593,043 who had been born in the state had removed, while 476,966 had come in from other states. Finally, there were included in the population of the state in I860, 36,673 colored people. While from I80o to 1860 the white population had increased fifty-one times, the colored had increased one hundred and eighty-seven times. There were very few colored people in the Reserve counties, Erie with one hundred and forty-nine and Geauga with seven being the two extremes. About three-fourths of the whole number of colored people lived south of the national road. ${ }^{2}$

During the early immigration into the Northwest Territory, there were five chief centres of settlement within the boundaries of Ohio. There was, first, the Ohio Company's purchase, including approximately the present Washington, Athens, Meigs and Gallia counties, settled by New Englanders. Secondly, the Symmes purchase, embracing a tract of land in the southwestern part of the state between the two Miami rivers, was settled by immigrants from New Jersey, Pennsylvania and the South. Next, there was the tract be-

1 Ohio ranked second among the states in German population, third in English, fifth in Irish and Scotch and tenth in British American. Of the cities, Cincinnati had a foreign population of forty-six per cent of her total, Cleveland, forty-five per cent, and Dayton, twenty-eight per cent with German and Irish predominating.

${ }^{2}$ These statistics of population have been taken from the U.S. Census of 1860 . 
tween the Little Miami and the Scioto rivers, which Virginia had reserved to provide bounties for her Revolutionary soldiers, and which consequently was settled by people from Virginia and Kentucky. The Seven Ranges, comprising the first land surveyed by Congress in the Northwest Territory and including the border counties along the Ohio river north of the Ohio Company's purchase, formed a fourth district, which was settled largely by Germans and Scotch-Irish from Pennsylvania and Virginia. Lastly, there was the Western Reserve, including the twelve counties in the northeastern corner of the state beginning with Erie and Huron; this had been withheld by Connecticut when she ceded her western land claims to the government, and was settled almost entirely by New Englanders.

As the other sections of the state were opened to settlement by Congress, and with the construction of Zane's road and later the national road, settlers came into the Scioto valley from Pennsylvania, Virginia, Kentucky and the states farther south, the southern immigrants being made up for the most part of the non-slave-holding democratic element. Large numbers of these settlers were Scotch-Irish and Germans, the former locating mostly in the southern part of the state and the latter in the central and eastern counties. Considerable numbers of Quakers drifted in from the South, particularly from Virginia and the Carolinas, settling in Greene and Warren counties and other anti-slavery sections. The colored population of the state was being constantly recruited before the war, not only by the harboring of runaway slaves, but also by the settling of freed slaves on little farms purchased for them by their masters in anti-slavery sections of the southern part of the state. ${ }^{1}$

${ }^{1}$ For a discussion of the sources of Ohio's population see Chaddock, Ohio Before 1850; in Columbia University Studies in History, Economics and Public Law, vol. xxxi. 
The political complexion of Ohio was determined largely by the location of these various population elements. The Reserve was strongly Whig until I850, when Cuyahoga, Medina, Portage, Trumbull and Erie counties went Democratic and remained so until I854, while Lake, Geauga and Ashtabula were carried by the Free Soilers. All, however, joined in the Republican movement, and in I860 this was the centre of radical Republicanism in the state. The section included in the Ohio Company's purchase was sometimes called politically the "Reserve of the South." While modified somewhat by southern influence, it was, next to the northern Reserve, the most radical antislavery section of the state. In the southwestern part lay a third section, extending from Marion county on the north, Franklin on the east, Warren and Clinton on the south and the state line on the west, which was dominated by the Whigs and later by the Republicans, yet owing to the fact that it was settled largely by Kentucky Whigs whose principal exponent was Thomas Corwin, it was much more conservative than the two sections before mentioned. The counties included in the Seven Ranges and those immediately to the west formed a debatable ground between the two parties. Owing to the mixture of the population, elections were usually close. The other sections of the state, with the exception of Lucas county, were usually Democratic, due to the large element of Scotch-Irish and Germans.

In 1832 Jackson carried the state by 4,707 majority while four years later Harrison's majority was 8,720. During the decade from 1834 to 1844 the state elections alternated between the Whigs and Democrats by majorities ranging from 2,000 to 16,000 . Then the Whigs held control until I85I, when, with a full Free Soil ticket in the field, the Democrats won by a majority of 26,106 in a total vote which was 15,089 less than that of 1849 . The Free Soilers 
in that year polled 16,910 votes, nearly three-fourths of which came from the Reserve. In $185^{2}$ Pierce carried the state by a majority of over 16,000 , while Hale received 31,682 votes. In the next year the Democrats carried 69 counties, their total vote being 147,663 as against a Whig vote of 85,857 and a Free Soil vote of 50,346 , the last named party carrying Ashtabula, Lake, Geauga, Clinton, Lorain and Summit counties of the Reserve and Clinton in the southwest.

With the organization of the Republican party, the state shows a readjustment to the new political conditions. In the election of 1855 , Belmont, Darke, Franklin, Montgomery, Ross and Scioto of the old Whig counties went over to the Democrats, while Columbiana, Williams, Hardin, Knox, Morgan and Paulding left the Democratic ranks for the new party. The Republican majority over the Democrats in that year was 15,75I, while the KnowNothings polled 24,276 votes. In regard to this KnowNothing vote, the state could be divided by a line drawn from the point on the east where the Ohio becomes the boundary across to the northern limit of Darke county. Of the $4 \mathrm{I}$ counties north of this line, only six, Mercer, Richland, Huron, Cuyahoga, Summit and Ashtabula, gave over IOO votes, while of the 47 counties south of this line, only 8 did not give that number while I7 gave over 300 . The largest numbers given by individual counties were; Hamilton 6538, Belmont I003, Gallia I099, and Highland 1256. Two counties, Madison and Gallia, were carried by this party. In the election of 1856 , the Know-Nothings polled 28,126 votes, the greatest gains being made in the northwestern quarter of the state and in the river counties from Columbiana to Scioto. By 1857 the movement had spent itself, and Van Trump, the candidate for governor, received only 10,272 votes. In Ohio as in the other states, 
this organization furnished a temporary home for some of the Whigs who were not especially hostile to slavery. In I855 Salmon P. Chase was elected governor on the Republican ticket by a majority of $\mathrm{I} 5,75 \mathrm{I}$, and was reëlected two years later by the narrow margin of $\mathrm{I}, 28 \mathrm{I}$ votes. In I859 Dennison, the Republican candidate, was elected over Ranney, his Democratic opponent, by a majority of 13,236 . Omitting the vote of 1857 , which was not normal, the average majority of the Republicans in the state elections from I855 to 1860 was $17,000 .^{1}$

The questions uppermost in Ohio politics at the beginning of the war period were, of course, those concerning the negro. The state had occupied an important position throughout the whole slavery controversy, both through the activity of the "Underground Railroad," and by the prominence of her political leaders. Because of the various elements in the population all shades of opinion on the subject were represented among the people, from the radicalism of Wade, Chase and Giddings, through the conservatism of Corwin and Ewing to the most extreme state rights doctrines of the Democracy. Not only were these questions of prime importance at the beginning of the period, but they were to continue to be such throughout the war, first in the matter of the immigration of negroes into the state, then as to the abolition of slavery as an incident of the war, and finally in regard to extending the franchise to the colored population of the state.

The negro, in I860, was without political privileges in Ohio. Throughout the half century of the state's existence there had been a sentiment against granting such privileges, though at the time of the adoption of the first constitution in 1802 this was not very marked. A motion in the con-

\footnotetext{
${ }^{1}$ The above election statistics have been taken from a compilation made by the secretary of state and published in his report for 1875 .
} 
vention to strike out the word "white" from the report of the committee on electoral qualifications was lost by a vote of fourteen to nineteen, while a proviso was actually passed giving suffrage to all male negroes and mulattoes of voting age then residing in the state. This was rescinded later only by the deciding vote of the president of the convention. $^{1}$ As adopted, the constitution limited the franchise to " all white male inhabitants above the age of twenty-one years, having resided in the state one year next preceding the election, and who have paid or are charged with a State or county tax." ${ }^{2}$ A proposition to allow limited slavery in the state was defeated by only one vote.

During the next few years, however, a great increase in the immigration of free negroes occurred, and through the predominance of the southern element in the legislature, a law was passed, January 5, 1804, forbidding any black or mulatto person to settle in the state unless he could furnish a certificate from some court of the United States of his actual freedom, and requiring all such persons then resident in the state, to register with the county clerk. It was made a penal offense to employ a negro unless he could present a certificate of freedom, and to harbor a fugitive slave or aid in his escape from the state. ${ }^{3}$ In 1807 this law was strengthened by prohibiting any negro from settling in the state unless he could within twenty days give bond to the amount of five hundred dollars as a guarantee of his good behavior and support. The fine for harboring a fugitive was increased, and negroes were forbidden to give evidence in court in a case in which a white person was a party. ${ }^{4}$ Further acts passed during the years from 1824 to $183 \mathrm{I}$ prohibited the negro from jury service, deprived
'Cf. Journal of the Convention.
${ }^{2}$ Article iv, sec. i.
${ }^{3}$ Lawes of Ohio, vol. ii, p. 63.
4 Ibid., vol. v, p. 53 . 
him of poor maintenance and excluded him from the public schools. ${ }^{1}$ It was these acts taken together which constituted the so-called "Black Laws" of Ohio, and by them the colored people of the state were put in the position of residents by toleration.

However, in the interpretation of these laws, and of the constitutional provision, the courts repeatedly held that the word "white" comprehended all persons having more white than colored blood." In some of the counties, persons having even a preponderance of negro blood exercised the voting privilege, and the sentiment of the people was such as not to interfere. In I849 the Free Soilers held the balance of power in the legislature, and by a combination with the Democrats to elect Chase to the United States Senate, these "Black Laws" were all repealed except those relating to the jury service and poor maintenance. ${ }^{3}$

In the midst of the excitement over the Federal legislation of 1850 , a convention assembled to draft a new constitution for the state. Notwithstanding the presentation of a number of petitions praying for the enfranchisement of the negro, the fundamental law was not changed in this respect, principally because of the feeling that any such change would prevent its ratification at the polls. The franchise was conferred on "every white male citizen of the United States of the age of twenty-one years" who possessed certain residence qualifications." Ore concession was made to the negro in that he was to be included in determining the apportionment for the state legislature.

In the election of 1855 the new Republican party ob-

'Laws of Ohio, vol. xxvi, p. 43; vol. xxvii, pp. 35 and 72; vol. xxix, p. 94 .

${ }^{2}$ Ohio Reports, vol. iv, p. 53; vol. xi, pp. 372 and 376; vol. xii, p. 237.

${ }^{3}$ Schuckers, Life of Chase, pp. 90 et seq.

*Art. v, sec. i. 
tained a majority in both branches of the legislature, and proceeded to enact a series of Personal Liberty laws. The first of these forbade the confinement in any of the prisons or jails of the state, of "any person or persons charged with simply being a fugitive from slavery." 1 A second forbade the bringing into the state of any person with the intention of holding him as a slave, and declared that " every person coming within this State otherwise than as a person held to service in another State under the laws thereof and escaping into this State, shall be deemed and held in all courts as absolutely free." Any person seizing or arresting another upon pretense or claim that he was a fugitive from justice, was to be deemed guilty of false imprisonment, and if anyone attempted to remove a person out of the state for the purpose of holding him as a slave in some other state, he was to be held liable for the crime of kidnapping. Nothing in the law was to apply to any act done by any persons under authority of the Constitution of the United States or any law made in pursuance of it. ${ }^{2}$ A third act provided that no person should attempt to arrest or kidnap any free black with the intention of carrying him out of the state, and that no negro claimed as a fugitive should be kidnapped or carried out of the state without being first taken before the proper court and the proof established according to the laws of the United States that he was property. $^{3}$

This legislation, while presuming not to interfere with the execution of the Federal laws, yet furnished an opportunity to hamper the return of fugitive slaves wherever possible. It was not permitted to remain long in operation, however, for in the election of 1857 the Democrats carried

${ }^{1}$ April 16, 1857. Laws of Ohio, vol. liv, p. I70.

${ }^{2}$ April I 7, 1857. Ibid., p. 186.

${ }^{3}$ April 17, 1857. Laws of Ohio, vol. liv, p. 221 . 
both branches of the legislature, and at the first session of the new Assembly in $185^{8}$ the first two of these acts were promptly repealed. ${ }^{1}$ An act known as the "Visible Admixture law" was passed which provided that the judges at any election should reject the vote of any person "whenever it shall appear to such judge or judges that the person so offering to vote has a distinct and visible admixture of African blood." It was made the duty of the judges of the courts of common pleas to give this act especially in charge to the grand jury at each term of court. ${ }^{2}$ Throughout the period of the struggle over slavery the Democratic party stood on the sentiment expressed in this act. In the state platform of 1858 it was endorsed as "eminently wise and judicious and calculated to promote the best interests of the state and the prosperity of the people," and the party was placed on record as "opposed to negro suffrage and negro equality without reference to shade or proportion of African blood."

This attempt of the legislative department to put an interpretation on a clause of the fundamental law of the state was not allowed to go unchallenged by the Republicans, who still retained control of the Supreme Court. In a case which went up to it from the Democratic county of Butler, where the election judges had rejected the vote of a man of one-eighth African blood in the presidential election of 1856, the court held, February 14, I860, that though the clauses.concerning suffrage were worded differently in the two constitutions, there was no change in the meaning, and as the clause of the first constitution had been interpreted to include persons having a preponderance of white blood, it remained only for the judges to abide by these decisions and hence to declare the person entitled to vote.

${ }^{1}$ Laws of Ohio, vol. 1v, pp. 10 and 19.

${ }^{2}$ Ibid., p. 120. 
As to the "Visible Admixture law," the court held that it was not within the "scope of the legislative power to give to the courts an authoritative construction of a provision of the Constitution of the State." The simple question for the court to determine was, "in what sense the word 'white' was used in the Constitution, and in that sense, when ascertained, we suppose it to be obligatory both upon us and the General Assembly of the State." 1 With the coming-on of the war, other questions came into prominence, but after the close of hostilities, negro suffrage became a vital political issue in the state. ${ }^{2}$

RELATIONS WITH THE BORDER STATES DURING I859 AND I860

The campaign of 1859 was a notable one in the politics of the state, not only on account of the efforts of the Republicans to regain control of the legislature, but also because of the prominence given to the Fugitive Slave law of 1850. This act was brought conspicuously before the people in several of the northern states through the attempts of the slave owners to recapture their slaves under its provisions, but especially so in Ohio in connection with the OberlinWellington rescue case. The facts of this case were these. Two slave catchers came to Oberlin in September, $\mathrm{I} 858$, in search of an escaped slave. Discovering there a young negro who had escaped from a neighbor of theirs some two years before, they decoyed this negro some distance out of the village, where he was seized and hurried to Wellington, nine miles away, to be placed on a train bound for Columbus. A crowd, composed largely of students and professors from Oberlin college, pursued the party and rescued the captive. As a result, thirty-seven

${ }^{1}$ Anderson vs. Milliken, 9 Ohio State Reports, p. 568.

${ }^{2}$ Cf. chapter iv. 
citizens of Oberlin and Wellington were indicted in the United States District Court at Cleveland, for violation of the Fugitive Slave law. Two of these, one a colored man of unusual intellectual ability, were found guilty and sentenced to a fine and imprisonment. The case attracted wide notice throughout the North; and while the other prisoners were still in jail awaiting trial, an immense mass meeting was held in Cleveland, May 24th, addressed by Governor Chase, Senator Wade and other prominent anti-slavery leaders.

An application was made to the Supreme Court of the state for a writ of habeas corpus, directed to the District Court, ordering the release of the prisoners, and this threatened to produce a conflict of jurisdiction between the courts of the United States and the state. The Supreme Court was composed at the time entirely of Republicans, and it was confidently expected by the people of the Reserve that the writ would be allowed on the ground of the unconstitutionality of the law. In the face of this pressure, Chief Justice Swan delivered an able and courageous opinion which was concurred in by two of his associates, Judges Peck and Scott. He held that it was not in the province of the Supreme Court of Ohio to deny the right of Congress to legislate on a subject when its authority to do so had been well settled by the Supreme Court of the. United States in several decisions. Although his personal feelings were not in accord with his judicial opinion, he was compelled under his oath to sustain the supremacy of the Constitution and the laws, and remand the prisoners. ${ }^{1}$ The other two members of the Court, Judges Brinkerhoff and Sutliff, delivered a dissenting opinion holding the Fugitive Slave law unconstitutional.

19 Ohio State Reports, p. 77. 
In the meantime, the slave catchers had been indicted in Lorain county under the act of 1857 for kidnapping a negro and attempting to carry him out of the state. The matter was finally closed by an agreement of the parties concerned for a mutual annulling of all indictments. The two persons convicted served out their sentences and returned home to be received as conquering heroes. ${ }^{1}$

The decision of the Supreme Court was handed down on May 3oth, and four days later the Republicans held their state convention. Indignant at the refusal of the court to declare the law of 1850 unconstitutional, the radical element of the party refused to support Judge Swan, whose term was just expiring, for a renomination, and he was accordingly sacrificed. The platform demanded "that provision be made for reversing the decisions of the District and Circuit Courts of the United States, by appeal or writ of error, and for securing fair and impartial juries in prosecutions for alleged violations of the laws of the United States," and called for the "repeal of the Fugitive Slave Act of 1850 as subversive of both the rights of the states and the liberties of the people, and as contrary to the plainest duties of humanity and justice, and as abhorrent to the moral sense of the civilized world." ${ }^{2}$ William Dennison of Columbus, a representative of the strong anti-slavery element and one of the founders of the Republican party in Ohio, was nominated for governor.

The Democrats went into the campaign with Rufus $P$. Ranney of Cleveland, one of the ablest lawyers of the state, and a former Judge of the Supreme Court, as their candidate.

'Shipherd, History of the Oberlin-Wellington Rescue. See also Rhodes, History of the United States, vol. ii, p. 362.

2 The platforms as used in this study have been taken from a pamphlet entitled, "The Ohio Platforms of the Republican and Democratic Parties from 1855 to 1881." 
for governor. In their platform, in addition to opposing the granting of political rights to the negro, they expressed adherence to the doctrine of the Kansas-Nebraska bill, approved the Fugitive Slave law, and affirmed "the absolute sovereignty of the States of this Union in regard to their domestic institutions, and the perfect compatibility of the confederation of free and slave States to exist harmoniously together under the provisions of our Federal Constitution."

The campaign was a memorable one. In a series of joint debates the two candidates for governor spoke in all sections of the state. Both Lincoln and Douglas visited Ohio, and took part in the canvass. The Democrats made much of the sacrificing of Judge Swan, and while the more conservative Republicans attempted to attribute his defeat to other reasons, the radicals boldly asserted that it was due solely to his decision. ${ }^{1}$

Dennison's majority over Ranney in the election was about the normal Republican majority, and the legislature as chosen stood: Senate, twenty-five Republicans and ten Democrats; House, fifty-eight Republicans, forty-six Democrats and one Independent.

As this was to be the first of the war legislatures, an analysis of its membership may be of some interest. Of the

${ }^{1}$ A letter written by R. P. Spalding, who had been one of the attorneys for the defense in the trials at Cleveland, was reprinted widely in the press during the campaign. In it he asserted that Judge Swan was not dropped, as some said, because of his residence in Columbus. "He was dropped for the reason that he, as a judicial officer, recognized the Fugitive Slave enactment of 1850 to be of binding force in Ohio, and the two judges who were with him in opinion will be dropped in the same way so soon as they are reached in the order of time. We do not recognize men to be Republicans here in northern Ohio who will for a moment sustain this miserable enactment."

For the importance of the campaign in general political affairs, see Rhodes, History of the U.S., vol. ii, p. 380 . 


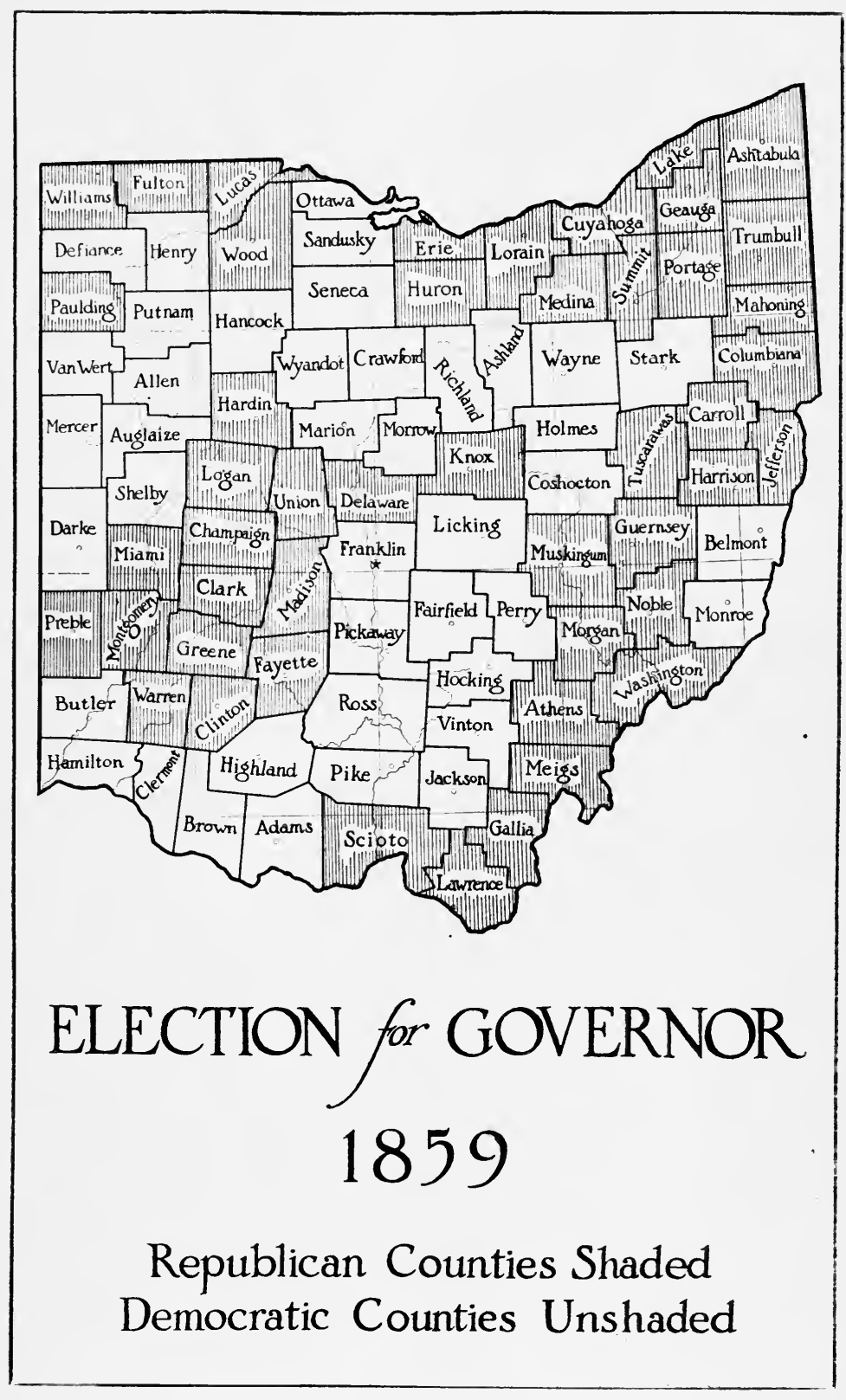



thirty-five members of the upper branch, twenty-four had never served in the Senate before, while only two were reelected from the preceding Senate. Only twenty of the one hundred and five members of the lower branch had served in the preceding House. As in this case, so throughout the period, very few members of the Assembly were reëlected to second terms. As to nativity, one-third of the Senators were natives of the state; while Pennsylvania, New York and Virginia contributed four each, Massachusetts and Connecticut three each, and several states furnished one each. Of the members of the House, forty-five were natives of the state; twenty-one were from Pennsylvania; fourteen, from New York; five, from Maryland; four, from Virginia; with several other states represented by smaller numbers. The large immigration into the state was thus reflected in the composition of the legislature, while the fact that so many of the members were connected with Pennsylvania, New York and the South by kindred ties, accounts in large measure for their conservative attitude on the great questions of the day prior to the outbreak of the war.

This legislature was called upon to undo the work of its predecessor, and to voice the sentiment of the party which was in control. In addition to the issues raised in the campaign, another question was injected into the politics of the state during the latter part of the year by the raid of John Brown. It was felt in Virginia that this was only the forerunner of larger expeditions by bands organized in Ohio and other northern states, and that efforts would be made to rescue Brown and his associates, or in case they were executed, to make reprisals on Virginia citizens and hold them as hostages. Governor Wise addressed a letter to President Buchanan stating his apprehensions, and asserting that if another invasion should assail the state of Virginia, he would " pursue the invaders into any territory and 
punish them wherever they could be reached by arms." A copy of this letter was sent to Governor Chase, with a repetition of the purpose to pursue invaders into the adjoining states. Chase replied under date of December Ist expressing ignorance of any such military preparations, and adding: "Whenever it shall be made to appear that unlawful combinations are being formed in Ohio for the invasion of Virginia, it will become the duty of the Governor to break them up and that duty will be promptly performed." As to the threatened invasion of Ohio, he said that the laws of the United States indicated the mode in which persons charged with crime in another state could be demanded, and assured the governor that the people of the state would require from her authorities the punctual fulfilment of every obligation to the other members of the Union. "They cannot consent, however, to the invasion of her territory by armed bodies from other States, even for the purpose of pursuing and arresting fugitives from justice." 1

In his annual message, January 2, I860, Governor Chase recommended the repeal of the "Visible Admixture law", and the reënactment of the Personal Liberty laws. In repeated instances, he asserted, the state had been

clandestinely entered and peaceful inhabitants, guilty of no crime but color, have been cruelly kidnapped; the Fugitive Slave Act, necessarily repugnant to public sentiment, and believed by a large majority to be unconstitutional in some of its conspicuous provisions, if not in its origin, has been executed within her limits with circumstances of aggravation which could not fail to excite the deepest feeling.

As to the raid of John Brown he said:

While we will not disavow just admiration of noble qualities, 
by whomsoever displayed, we must not the less, but rather the more, earnestly condemn all inroads into States, not merely at peace with us but united to us by the bonds of political union, and all attempts to excite within their borders servile insurrection, necessarily to involve the country in the calamities of civil as well as servile war.

Laying the correspondence of the governor of Virginia before the Assembly, he declared that while the people of Ohio would suffer no invasion of their own territory, they would countenance no invasion of other states. ${ }^{1}$

While Chase's attack on the Fugitive Slave law was resented by the conservatives of the party, the inaugural address of Governor Dennison, delivered on January 9th, was even more bold. He attributed the increase of population and the development of the resources of the state almost entirely to the fact that slavery was prohibited by the Ordinance of 1787 . The voice of the people of the state, he maintained, had been given against slavery. He denied the binding authority of the Dred Scott decision of the Supreme Court, and insisted that it was the duty of Congress to prohibit by express enactment the extension of slavery into any free territory. He would first check the aggressions of slavery and confine it within its existing boundaries; then he would have the government provide some means of promoting voluntary emigration of the free negroes to homesteads in a congenial climate. He suggested for this purpose the acquisition of some rich region in Central or South America and its erection into a province for the colored people under national supervision. ${ }^{2}$ This strong Republican doctrine voiced the true sentiment of the new governor. He was of the radical wing of the party, and in the acts of his administration he represented that element.

'Executive Documents, I859, pt. ii, p. 25.

'Ibid., p. 163. 
The first matter of importance to be taken up by the Assembly was the selection of a United States Senator to succeed George E. Pugh, who had been chosen by a Democratic legislature in 1854 . Chase was a prominent candidate for the place, and in the organization of the two branches his supporters were in the majority. Their candidate, Richard C. Parsons of Cleveland, was elected Speaker of the House. In the first caucus on the Senatorial question, held a few days after the organization, decided opposition was shown toward Chase among the conservative element, especially on account of the abolition sentiments expressed in his message. On February ist the Republican members met again, and the question was pushed to a vote in spite of the attempt of the conservatives to postpone action. Eleven of these were absent when the ballot was taken, and of the remaining seventy-one votes, Chase received fifty-one, Columbus Delano, for some years to be the opponent of Chase, received ten, and Thomas Corwin, eight, with one each for John Sherman and Valentine Horton, the Representative in Congress from the Meigs county district. In the Assembly a resolution of the Senate to proceed to joint convention for the election of a Senator passed the House by the narrow margin of two votes, six of the conservatives voting with the Democrats against it. On the final ballot, Chase received seventy-six votes, Pugh, fifty-three, while five conservatives cast their ballots for Corwin. ${ }^{1}$

This division of the Republicans into radicals and conservatives appeared throughout the session on most of the important measures that came up. In the House six of the conservatives $^{2}$ usually voted with the Democrats on meas-

${ }^{1}$ House Journal, 1860, p. 158.

${ }^{2}$ These were Collings of Scioto, Hamilton of Logan, Jolly of Highland, Nigh of Lawrence, Parrott of Montgomery and Wood of Ottawa. 
ures proposed by the radicals and were able in this way to block legislation. In the Senate, Harrison of Madison, Jones of Delaware and Moore of Butler were the conservative leaders, while Professor Monroe of Oberlin, James A. Garfield of Cuyahoga and Jacob D. Cox of Trumbull, a son-in-law of the President of Oberlin College, championed the doctrines of the Reserve.

During the latter part of January, the legislatures and state officials of Kentucky and Tennessee, who had assembled at Louisville to celebrate the completion of the Louisville and Nashville railroad, were invited to visit Columbus as guests of the state. In presenting the invitation at Louisville, Garfield, as chairman of the legislative committee, sounded a note which, when heard from the Peace Democrats later, was to be denounced as treasonable. He said :

Brethren, we have too long heard of a North and a South. Their angry words have too long vexed the hearts of our fellow citizens. But there is a third voice to be heard ere long. I hope and believe the day is not far distant when the great West shall speak and her voice shall be heard from sea to sea. In that voice shall mingle no tones of doubt or uncertainty. In that utterance shall be heard no note of disunion. For while this mighty river bears on its bosom the wealth of this great valley, so long must this circle of States be undivided and the bonds of union unbroken.

Three days were spent by the guests within the state, and in the speech-making which formed an important part of the entertainment, much was said of the natural community of interests and feeling of the states of the Mississippi valley, and of the harmony which should exist among them. In responding to the toast, "Ohio and her Guests", Governor Dennison said: 
The people of Ohio ask no peculiar privileges under the Constitution. They cheerfully recognize as belonging to their brethren all the rights they claim for themselves. The exclusive right of the people of every State to establish and maintain undisturbed their domestic institutions, lies at the foundation of the National confederacy. ${ }^{1}$

It was impossible for the good fellowship of this occasion to endure through the political affairs of the succeeding months, but it is of importance in showing the community of feeling existing between Ohio and the border states before the war.

Following the recommendations of Governor Chase in his annual message, the program of the majority party in the legislature included the reënactment of the Personal Liberty laws and the repeal of the "Visible Admixture law," while the Democrats labored to secure legislation prohibiting the immigration of negroes into the state and further to restrict the privileges of those already within her borders.

With the first of these ideas in view, bills were introduced in the House by Baldwin of Mahoning and in the Senate by Monroe of Lorain, to prevent slaveholding and kidnapping in Ohio. Monroe's bill was referred to a select committee of Republicans from which it was reported favorably and passed, against the opposition of the conservatives and Democrats. ${ }^{2}$ The House bill was reported from a select committee with a section added repealing the acts of June 19, I835, and April I7, I857, which the committee held introduced the principle of class legislation. ${ }^{3}$ It was

${ }^{1}$ A complete account of this visit was published under the title "Visit of the Legislatures of Ky. and Tenn." Cinn., I860.

${ }^{2}$ Senate Journal, 1860, pp. 20 and 228.

${ }^{3}$ The report of the committee is printed in the House Journal for 
tabled together with the Senate measure. Bills were also introduced to prohibit the use of the prisons and jails of the state for the confinement of persons charged merely with being fugitives from slavery, but in neither house did they get further than to select committees.

The Senate passed a bill to repeal the "Visible Admixture law", but the House tabled it. A similar bill, introduced in the House, was referred to the judiciary committee, which recommended that it be indefinitely postponed. The opinion of the majority was that the law was merely a legislative demand for a review by the courts of their earlier decisions which was not inconsistent with the rights or dignity of a judicial body, and that the law ought to stand until its constitutionality should be determined. The members of the committee from the Reserve presented a minority report, holding that the interpretation of any provision of the constitution was a judicial, not a legislative, act. "If the legislature has the power to give construction to any provision of the Constitution, that construction may so enlarge or restrict as to do away with the effect of the provision." 1 The bill with the reports was laid on the table, and was not taken up again during the session. These reports were made on February 7 th, just a week before the decision of the court in the Butler county case was announced. ${ }^{2}$ The opinion was delivered by Judge Gholson, the new member of the court who had been put on the ticket in place of Judge Swan. On this decision the Reserve was content to let the matter rest, without any legislative action, while the conservatives were much dissatisfied with it. The Democratic press commented on the fact that no dissenting

I860, Appendix, p. I26. The act of 1835 referred only to the kidnapping of white persons, while that of 1857 referred to the kidnapping of free negroes.

'House Journal, 1860, App., p. 163.

${ }^{2}$ Cf. supra, p. 22. 
opinion was delivered, and concluded that Judges Peck and Scott had surrendered to the Oberlin faction through fear of the condemnation pronounced on them by Spalding. ${ }^{1}$

The Democrats, backed by many petitions from the southern counties on the subject, kept up an agitation for the restriction of the immigration of negroes into the state. On the second day of the session a measure was introduced in the House providing that after the first of the following July, it should be unlawful for any negro or mulatto person to come into the state, and requiring such as were already residents to be registered by the assessors and to obtain certificates of registration. ${ }^{2}$ The bill went to the judiciary committee, which reported unfavorably to its passage. One of the members, the representative from Greene county, annexed to the report the reasons for his decision. While admitting the magnitude of the evil and the social repugnance of the two races, he put his objection on constitutional grounds. By the decision of the courts of the state, mulattoes were held to be citizens of the United States and hence the law would deprive them of their privileges guaranteed by the national Constitution. His ultimate solution was that recommended by Governor Dennison. During the discussion of this measure, which continued from time to time throughout the session, the Democrats emphasized the idea that they did not wish to make the question a political one, and put their opposition to immigration purely on social and industrial grounds. By a majority of five, however, the Republicans were able to have the bill indefinitely postponed, ${ }^{3}$ and during the next session, when the author moved to take up the matter, his motion was lost by a tie vote. ${ }^{4}$

1 Ohio Statesman, February i 5 th.

${ }^{3}$ Ibid., I860, p. 523.
${ }^{2}$ House Journal, 1860, p. 21.

${ }^{4}$ Ibid., I861, p. 60. 
In addition to these things, the question what attitude the state should take in regard to the raid of John Brown claimed much attention of the legislature. As soon as the House was organized, a set of resolutions on the subject was offered by Hutcheson of Madison, an extreme Democrat, while the matter was brought before the Senate by means of a bill introduced by Harrison. In the Hutcheson resolutions, ${ }^{1}$ the raid was characterized as an outrage not only against the commonwealth of Virginia but against the government of the United States, and the people of Virginia were congratulated on the suppression of the outbreak. The citizens of Ohio, they declared, "disavow, as they always have done, any right or wish to interfere in any manner with the domestic institutions of the other States of the Union." It was provided that a copy of the resolutions be sent to the governor of Virginia to be laid by him before the legislature of that state. As a substitute, the radicals offered a resolution asserting that the people of the state, looking upon slavery as an evil, "feel it to be their duty to use all power consistent with the National compact to prevent its increase, to mitigate and finally to eradicate the evil." 2 The conservatives proposed a second substitute which declared opposition to all interference with slavery as it existed, but also to its extension, and denounced all unlawful combinations against the peace and safety of other members of the Federal Union. The southern states were called upon to enact legislation which would protect the lives and property of northern citizens sojourning in the South. $^{3} \quad$ This latter substitute was adopted by a combination of the radicals and conservatives, but on the question of incorporating it in the radical resolutions, fourteen Republicans voted with the Democrats, thus defeating it. ${ }^{4}$

${ }^{1}$ House Journal, 1860, p. 22.

${ }^{3}$ Ibid., p. 398.
2 Ibid., i860, p. 397.

4 Ibid., p. 399. 
The conservatives, holding the balance of power, refused to permit either the Hutcheson or the radical resolutions to pass.

The original resolutions were sent to the governor of Virginia by the Democrats, with an explanation of the action of the House, and an assurance that, though repudiated by a Republican legislature, they reflected the sentiments of at least one hundred and seventy-one thousand voters of Ohio. Governor Letcher, in transmitting them to his legislature, said:

It is a source of infinite satisfaction to me to know that sentiments so natural and conservative as those . . . are entertained by the minority of the members of the House of Representatives of that State. . . The patriotic spirit they have exhibited is, in times like these, when dangers threaten us on all sides, worthy of the highest commendation and should be appropriately responded to.

The legislature acted at once by a resolution accepting the sympathy of the senders and rejoicing in their patriotic purpose " faithfully to observe and respect the rights and institutions of the slaveholding States guaranteed by the Federal compact, and to promote that comity between the States so essential to a longer continuance of the Union." The Republicans in refusing to pass the resolutions, it was held,

furnish additional proof of a settled purpose of hostility by their party to the institutions of the slave-holding States, of an utter insensibility to the fraternal relations which ought to exist between the citizens of a common government, and a reckless disregard of the sacred obligations of the Federal Constitution, which, if persisted in, must eventuate in a dissolution of the Union. ${ }^{1}$

${ }^{1}$ Copies of all the documents are printed in the Cleveland National Democrat, March 27th, and Cincinnati Enquirer, March 3 Ist. 
The bill which was introduced in the Senate by Harrison, dubbed by the radicals the "Harrison Servility bill," made it a misdemeanor for any person to set on foot or provide arms for any military enterprise or expedition against the territory or people of any other state, or to enable any persons forcibly to resist the execution of the laws of any state. ${ }^{1}$ In giving his reasons for urging its passage, its author held that Ohio's position on the slavery question had been greatly misunderstood, and that it was the duty of the Assembly to make it clear.

The passage of this bill in a becoming spirit will be appreciated by all right-minded men as the olive branch of peace; and having done this act of preventive justice, we can with much more unanimity and moral power resist all attempted encroachments from any other quarter. ${ }^{2}$

After some debate the measure was referred to a select committee consisting of two conservatives and one radical. By a report signed by the conservative members, its passage was recommended, while Monroe, the minority member, presented a report giving as reasons why the bill should not become a law : that it was unnecessary, since the offense was one which never had existed and never would exist in Ohio; that it would do a positive injury, since its passage would create an inference in the slave states that there was a tendency among the citizens of Ohio to set on foot hostile expeditions against their territory; and that in view of the aggressions of slavery upon the rights of the people of Ohio and the other free states, it would be time enough to pass such laws when the legislatures of the southern states should manifest a disposition to repair the wrongs which were being inflicted daily upon the persons and prop-

${ }^{1}$ Senate Journal, r860, p. II .

'Ibid., App., p. 227. 
erty of the people of Ohio. ${ }^{1}$ A strenuous debate which brought out the wide difference of opinion between the Reserve and the southern portion of the state, occupied the time of the Senate for some days, but the conservatives combined with the Democrats were not quite strong enough to command a majority, and on February 8th the bill was postponed indefinitely by vote of eighteen to fifteen. A few days later it was introduced in the House, and after some discussion, action was postponed on the last day of the session until the following January. ${ }^{2}$ When during the next session it was reached, the excitement had passed, and the bill was referred to the committee on Federal relations from which it was never reported. ${ }^{3}$

At the same time the legislature was wrestling with this problem, another matter came up. Owen Brown, a son of John Brown, and Francis Merriam were indicted at Charlestown, Virginia, for treason, murder and inciting slaves to insurrection, and both being in Ohio at the time, a requisition was made by Governor Letcher on the Ohio executive February 27th for their delivery. Dennison refused to issue warrants for their arrest and delivery on the ground that no sufficient case was presented against them. The reasons for his conclusion were set forth in an opinion of the attorney general of the state. They were, that since there was no state law on the subject of extradition the United States Constitution and the law of I793 must be the guide, and in these were found three provisions which bore on the case: (I)the person must have been charged in another state by indictment or affidavit with the commission there of "treason, felony or other crime"; (2) he must have fled from that state to escape its justice; and (3) de-

'Senate Journal, 1860, App., p. 230. Also Senate Journal, p. 147.

${ }^{2}$ House Journal, 1860, pp. 263 and 560.

${ }^{3}$ Ibid., I861, p. 33 . 
mand for surrender accompanied by an authentic copy of the indictment or affidavit must have been made by the executive authority of the state from which the flight was made. The conclusion was, that since actual flight must be proved and no evidence of such had been furnished, this one barrier was sufficient to show that the case did not warrant extradition. ${ }^{1}$

Governor Letcher, in presenting the matter to his legislature, March I4th, a few days before the Hutcheson resolutions were transmitted, ridiculed the reasons for refusal, and cited an instance of a requisition of the Ohio governor on him which was identical in form with his own. $\mathrm{He}$ concluded his comment on the matter by saying:

If such is to be the policy of the non-slaveholding States, we must adopt such measures for protection against these gross outrages upon our rights as will be suited to the case. We must adopt retaliatory measures, and thus show them that we are determined to resist, with becoming spirit, every encroachment upon us and every refusal to comply with constitutional obligations and laws intended for our protection. ${ }^{2}$

Feeling in regard to the affair ran high in the state. The Democratic press rated Dennison as a tool of the Oberlin school of politicians. The Cincinnati Enquirer was especially denunciatory in its comments and held that in the governor's action, he had made a raid on the constitution and laws of the land less defensible and more dangerous than that of John Brown himself. " A " sympathy meeting ", attended by both Brown and Merriam, was held at Jefferson, the home of Giddings in the Reserve. In the legislature,

${ }^{1}$ The correspondence between the governors is given in the Cincinnati Commercial for March 14, 1860. Cf. also Ohio Statesman, March IIth.

${ }^{2}$ Ohio Statesman, March 22, 1860.

${ }^{3}$ Editorial, April I9th. 
a resolution was introduced by Hutcheson calling on the governor to lay before that body the papers in the case, but no action was taken on it. ${ }^{1}$

A few days after this correspondence, a requisition came from Governor Magoffin of Kentucky for one Lago, charged with the crime of having enticed a slave away from her master and assisted her in an attempt to escape. Dennison, in this case also, refused to surrender the person, and sent an opinion of his attorney-general which held that all the proceedings were in due form if the alleged offense could be considered as either "treason, felony or other crime "; ${ }^{2}$ but maintained that it did not rank among those offenses upon which the constitutional provision was intended to operate. It was not a crime by the common law as it stood when the Constitution was adopted, nor was it regarded as a crime by the usages and laws of civilized nations. Hence the governor had no authority to comply with the requisition. In his reply, Governor Magoffin held that many things were now crimes which were not by the common law at the time the Constitution was adopted, and that since the offense of assisting a slave to escape was a crime in Kentucky if not in Ohio, by the reasoning of Governor Dennison the laws of one state might be annulled by another. As to the opinion of the attorney-general, Magoffin said that such ideas were not in vogue when Kentucky came up to help Ohio against the British invaders, and reminded the Ohio executive of his speech made on the occasion of the visit of the Tennessee and Kentucky legislatures, in which he said that Ohio wanted no special privileges under the Constitution. ${ }^{3}$

${ }^{1}$ House Journal, 186o, p. 392.

${ }^{2}$ U. S. Constitution, art. iv, sec. 2.

${ }^{3}$ Ohio Statesman, June Igth. 
On this refusal to honor the requisition, Governor Magoffin, on behalf of his state, applied to the United States Supreme Court for a writ of mandamus to compel the surrender of the fugitive. In delivering the opinion of the court on this request, Chief Justice Taney held that the word "crime" was intended to include every offense made punishable by the laws of the state in which it was committed, and that the constitutional right to demand a fugitive implied the corresponding obligation to deliver without any reference to the character of the crime charged or to the policy or laws of the state from which the fugitive had fled. But since neither the Constitution, nor the law of 1793 enacted to carry out its provisions, provided any means to compel a state executive to do his duty in this regard or to inflict any punishment for his neglect or refusal, the duty must be considered only a moral one. Hence the conclusion was that "if the Governor of Ohio refuses to discharge this duty, there is no power delegated to the General Government either through the Judicial Department or any other Department to use any coercive means to compel him." 1

A third case arose in regard to one Kennedy, who stole some negroes in Tennessee, took them to Virginia, sold them, and then fled into Ohio. The governor again refused to honor a requisition, on the ground that as slaves were not recognized as property in Ohio, it could be no crime to steal them. ${ }^{2}$

By thus refusing to extradite a person for an offense which was not a crime in Ohio, Governor Dennison would not only protect those who, because of their belief in the "higher law" of freedom, were instrumental in aiding

${ }^{1} U$. S. Supreme Court Reports, 24 Howard, p. 66. The opinion was not delivered until March, I86I. Cf. infra, p. 69.

${ }^{2}$ Ohio Statesman, May 3ist. 
slaves to escape, but would also make Ohio the refuge of those who like Kennedy had only criminal motives. Party feeling, already high, was intensified by this action, and party lines were more sharply drawn not only between the two parties, but also between the radicals and conservatives of the Republican party. The radicals controlled the executive and judical departments and the upper branch of the legislature, while the conservatives held the balance of power in the lower branch. The Assembly had adjourned just about the time the first request for extradition was made, and hence took no action on the matter, but in the politics of the year the issue was joined on the radical doctrines.

\section{PARTY CONVENTIONS AND CAMPAIGN OF I860}

The first convention of the year I860 was held by the Democrats on January $5^{\text {th, }}$, to select delegates to the national convention. The resolutions as adopted expressed approval of the Cincinnati platform of 1856 , endorsed Douglas for the Presidency, declared for the non-intervention of Congress in reference to slavery in the states and territories, and called for the execution of the laws for the suppression of the African slave trade and the rendition of fugitive slaves. The vote on the Douglas resolution was taken by counties and carried, two hundred and forty-two to ninety-four, the opposition coming mostly from the southern counties. In the committee on resolutions an attempt was made to insert a plank endorsing the administration of President Buchanan, but it was lost, seven to fourteen. The Buchanan men then offered their resolution in open convention. A compromise substitute was finally accepted, which endorsed the administration in certain specific things, such as the adjustment of the difficulties with Great Britain in regard to the right of search, the enforcement of the neutrality laws, and the impartial execution of 
the acts of Congress for the suppression of the African slave trade and for the rendition of fugitive slaves. In choosing delegates-at-large, the nominees were all made to pledge support to Douglas. A selection was made as follows: George E. Pugh, whose term in the Senate was just about to expire; D. P. Rhodes, a cousin of Douglas; George W. McCook, once attorney-general of the state; and $\mathrm{H}$. J. Jewett, a former United States district attorney. The district delegates included David Tod, who was destined to be the next governor of the state, and H. B. Payne of Cleveland, who was to be prominent in Democratic politics during the war period. ${ }^{1}$ This delegation stood solidly for Douglas in the Charleston convention, and on the re-assembling of the delegates at Baltimore, Tod was made the presiding officer. $^{2}$

The Republican convention, held on March Ist, adopted a resolution recommending Chase for the Presidency, by vote of three hundred and eighty-three to sixty-nine. Sixtyfive of the counties voted solidly for it while seventeen, mostly in the southern quarter of the state, were divided, and Highland, Madison and Tuscarawas voted unanimously against it. As delegates-at-large, Valentine B. Horton of Meigs, a conservative, Conrad Brodbeck of Montgomery, a German Socialist, David K. Cartter of Cuyahoga, a radical, and Thomas Spooner of Hamilton, a recruit from the Know-Nothing ranks, were chosen. ${ }^{3}$

Shortly before the national convention met, a movement was begun to secure the nomination of Wade for the Presidency. The possibility of accomplishing this led many of the party leaders to his standard because of their aspirations

${ }^{1}$ Account of the Convention in Ohio Statesman, January 6th.

'Stanwood, History of the Presidency, p. 286.

${ }^{3}$ Ohio State Journal, March $2 \mathrm{~d}$. 
to succeed him in the Senate. John H. Geiger, Governor Dennison, Thomas Corwin and Columbus Delano identified themselves with this movement. Thus there was a split in the Ohio delegation in the convention, and this left the party divided throughout the war period into Wade and Chase factions.

During the summer, all of the parties represented in the national campaign held state conventions in Ohio. The Re-

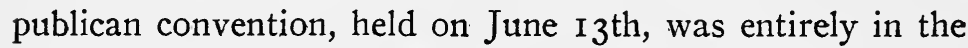
hands of the radicals. The Chicago platform and nominee were endorsed, and through the efforts of the Giddings forces, a plank was added reaffirming the declaration of principles adopted in the state convention of the preceding year. To head the ticket, Judge Brinkerhoff, one of the minority of the Supreme Court who held the Fugitive Slave law unconstitutional, was renominated. ${ }^{1}$

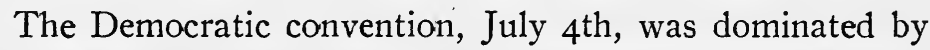
the Douglas supporters. McCook, Vallandigham, then representing the Dayton district in Congress, Jewett and Payne were prominent, the first presiding over the sessions, and the others serving on the committee on resolutions. The platform accepted the issue " tendered by the Republican party in the renomination of Judge Brinkerhoff, of the nullification or the enforcement of the Fugitive Slave law," condemned the "irrepressible conflict" doctrine, declared against negro suffrage, denounced the John Brown raid and endorsed Douglas and Johnson. The proposal of a resolution by L. W. Hall, an ex-member of Congress from Crawford county, declaring the opinion of the convention to be that every Democrat in Ohio should be at liberty to vote for either Breckinridge and Lane, or Douglas and Johnson, raised much confusion, and after the Breckinridge men

1 Ohio State Journal, June 14th. The Ohio State Journal was the official organ of the party. 
had been denounced as disorganizers, Hall and his friends withdrew from the convention. There was some talk of nominating Judge Swan to head the ticket against Brinkerhoff, but the proposition did not meet with favor, and his name was not presented. Thomas J. Smith of Dayton was nominated. ${ }^{1}$

When the Breckinridge men left the convention, they held a separate meeting under the leadership of several of the Federal office holders, and effected an organization. An executive committee was selected, with instructions to prepare an address to the Democracy of the state, and to call a state convention. Meetings were held in several sections of the state during July. In due time the address appeared, asserting that every Democrat should be at perfect liberty to chose between the Breckinridge and Douglas tickets, and contrasting the doctrines of the two factions. In the call, August 7 th was fixed upon as the date for holding the state convention. Local organizations were effected, so that when the delegates assembled almost every county was represented. The platform pledged support to Breckinridge and Lane, reaffirmed the declaration of the Ohio convention of 1857 endorsing the Dred Scott decision, approved the administration of Buchanan in everything "except in the retention in office of men who wage an open and undisguised war upon the President and all who support his administration," and maintained that the people of Ohio should "cease their aggression upon the people of the slave holding States, and repeal all hostile and unconstitutional laws on the statute books of Ohio against them." It had been agreed by the leaders beforehand to nominate a full state ticket, but this was abandoned owing

${ }^{1}$ Ohio Statesman, July 5th. This paper, edited by Geo. W. Manypenny at Columbus, was the official organ of the Douglas party. 
to vigorous protests from the editors of the rural papers, who claimed not only that they would be ruined through the falling-off of advertising, but that it would defeat the Democratic candidates in every county in the state. ${ }^{1}$

In a few counties Breckinridge tickets were put in the field, and in three congressional districts candidates were nominated. In the sixth district, the Douglas men were defeated in the convention and a Breckinridge man was nominated. In the ninth and twelfth districts, third candidates were nominated. ${ }^{2}$

The Constitutional Unionists were also organized in the state, the movement having its stimulus and direction in Cincinnati, where the first meeting was held on April 5th. A resolution was adopted at that time calling on the conservative men of all parties to meet at Columbus on the I8th of that month to select delegates to the national convention. In accordance with this call, about twenty delegates assembled and endorsed Bell and John McLean. On July Igth a large Bell and Everett ratification meeting was held at Cincinnati, at which the principal speakers were Lewis D. Campbell and John Scott Harrison, both old-line Whigs. Resolutions were adopted pledging support to the candidates and opposing any alliance with any other party. A mass convention was recommended to meet at Chillicothe on August I6th. A local organization was effected and a county committee named. On August 7 th, a county convention was held at which were selected a full county ticket

${ }^{1}$ Cleveland National Democrat, August roth. This paper was established at Cleveland by the leaders of the Breckinridge faction and Charles B. Flood, formerly of the Ohio Statesman, was put in charge.

${ }^{2}$ The Sixth District was composed of Adams, Brown, Clermont and Highland counties; the Ninth was composed of Ottawa, Sandusky, Seneca, Wyandot, Crawford, Marion and Hardin counties; and the Twelfth, of Franklin, Licking and Pickaway counties. 
and a congressional ticket for the two districts of Hamilton county. ${ }^{1}$

In pursuance of the recommendation, a call signed by fourteen names was issued. When the convention assembled at Chillicothe, it numbered about two hundred delegates under the leadership of Harrison, Campbell, ex-Governor Allen Trimble, Van Trump and Vallandigham. The first two of these, as already noted, were old-line Whigs; the next two were from the Know-Nothing ranks; while Vallandigham was present to prevent the nomination of a candidate for supreme judge, so that the party could combine with the Democrats against Brinkerhoff. A committee named for the purpose recommended the endorsement of Bell and Everett, and the adoption of the platform: "The Union, the Constitution and the Enforcement of the Laws," It also condemned the conduct of the Republican party in Ohio in its effort to nullify the laws through the agency of the Supreme Court; declared that the repudiation of Judge Swan and the renomination of Judge Brinkerhoff merited the rebuke of a law-abiding people; and recommended that no candidate for supreme judge be nominated, but that every conservative Union man so vote as to secure the defeat of the Republican candidate. This report was adopted, and a state ticket and Presidential electors nominated. ${ }^{2}$

In addition to that of Hamilton county, there were a few other local tickets put in the field by this party. In four congressional districts, the first, second, third and seventeenth, ${ }^{3}$ candidates were nominated.

${ }^{1}$ Cincinnati Commercial, July 21st and August 8th.

${ }^{2}$ Ibid., August i7th.

${ }^{3}$ Hamilton county made up the Ist and $2 \mathrm{~d}$ districts, Butler, Montgomery and Preble the $3 \mathrm{~d}$, and Guernsey, Belmont, Noble and Monroe the $i 7$ th. 
The campaign was waged naturally on national issues, the contest over the supreme judgeship being the only local one of importance. There was a tendency for the Bell and Douglas men, and the Breckinridge and Lincoln men to unite, the Republicans urging on the Breckinridge faction in order to weaken the Democrats through the division of the party. - The press of the state divided among the various candidates, the majority of the papers supporting Lincoln. ${ }^{1}$ A conspicuous feature of the parades were the Lincoln "Wideawakes," young men throughout the state uniformed and drilled for assisting in all the Republican demonstrations.

At the state election in October the total vote cast for supreme judge was $4 \mathrm{I} 2,7 \mathrm{I} 6$, an increase of 56,893 over that cast for governor in the preceding year. Brinkerhoff's majority was 12,992, while that of the other candidates on the Republican ticket was almost twice as large. In the congressional elections, the Republicans had a plurality of 33,633 , yet the Democrats gained four districts. In the four districts in which the Constitutional Unionists had their own candidates, they polled 6,268 votes, the highest number in any district being 2,642 in the first. On the state ticket they polled 8,653 votes.

After the October election, a proposal was made to combine the Douglas and Bell men of the state on one electoral ticket. The Cincinnati Enquirer favored the idea, while the Ohio Statesman opposed it. A meeting of the committees and electors of both parties was called for October 23d, but only six members of the Douglas committee and five Douglas electors attended, so the matter was carried no further.

In the national election in November, the total vote was

${ }^{1}$ Of the papers of the state, 126 supported Lincoln, 80 supported Douglas, 8 supported Breckinridge and 2 supported Bell. Ohio State Journal, July $23 \mathrm{~d}$. 
442,936: of which Lincoln received 231,809; Douglas, 187,$42 \mathrm{I}$; Bell, I2,194; Breckinridge, I I,403; and Gerritt Smith, the candidate of the extreme Abolitionists, I36. The heaviest vote for Breckinridge came from the northeastern part of the state. Of twenty-seven counties that gave him over Ioo votes each, only nine were south of the national road. The Constitutional Union vote was strong in the southern portion of the state, where the old "Silver Greys ", or pro-slavery Whigs, to some extent cast their ballots for this ticket. North of the national road only four counties gave Bell over Ioo votes, while south of that line only eight did not give this number and five gave over 300. Lincoln carried fifty-nine of the eighty-eight counties, an increase of twelve over the number carried by the Republicans in the election of the preceding year.

\section{ATTITUDE OF OHIO ON SECESSION AND COMPROMISE}

The election over, Ohio was called upon, together with the other members of the Union, to consider the question of actual secession, which was precipitated by the adoption of the South Carolina ordinance in December. The situation gave rise to three lines of opinion among the Republicans throughout the North. There were, first, those who held that since the decision at the polls had been reached in a constitutional manner, it was the duty of the South to submit to it. Secondly, there were those led by Horace Greeley of the New York Tribune, who were willing to. recognize the right of secession and allow the southern states to go in peace. Finally, many thought that a fair compromise might again be made between the two sections as had been done in 1820 and $1850 .{ }^{1}$ During the session of Congress beginning on December $3 \mathrm{~d}$, various

'Rhodes, History of the U.S., vol. iii, pp. 138 et seq. 
schemes of compromise were proposed, the most widely discussed being that of Senator Crittenden of Kentucky. $\mathrm{He}$ would prohibit slavery in all territory of the United States held or to be acquired north of latitude $36^{\circ} 30^{\prime}$, and protect it in all territory south of this line. States should be admitted, north or south, either with or without slavery as their constitutions might provide. He would secure to the slaveholders ample protection for their property, and forbid any amendment to the national constitution which would give Congress power to interfere with slavery in any state in which it was a lawful institution. ${ }^{1}$ In the Senate, a Committee of Thirteen was selected to consider the grievances between the two sections and if possible suggest a remedy, while the House provided a similar one of Thirty-three, one from each state, for the same purpose.

While Congress was wrestling with the problem during the winter and spring, the Republicans in Ohio were engaged in a strenuous effort to find some common ground upon which the widely divergent elements of the party could unite. At first, the prevailing opinion seemed to favor peaceable secession. This was strongly endorsed in the southern part of the state, because of the disturbances to commercial intercourse with the South which any plan of forcible coercion would involve. It was acceptable to the Abolitionists of the Reserve, because by it the unnatural alliance with slavery, against which their leaders had long protested, would be dissolved.

Among the Republican papers of the state, the Ohio State Journal, the Cincinnati Commercial and the Cincinnati Press were strong advocates of this plan of adjusting the difficulty. The first of these began a series of editorials on

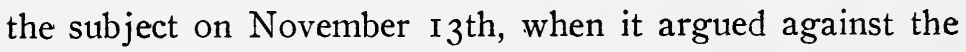

${ }^{1} \mathrm{McPherson,}$ History of the Rebellion, p. 64. 
coercion of any state to remain in the Union, on the ground that such action must inaugurate civil war. Four days later, it suggested the expulsion of South Carolina, because by doing so a wholesome terror could be struck into the secessionists of other states and a far more permanent influence for good be exerted than by compelling her to remain in the Union. On November 28th a plan was outlined which a state should follow in seceding. It should first make known its desire, either by petition or a formal application to Congress for dismissal, through the medium of a state convention representing a majority of the people, or through its Senators and Representatives. It would then lie within the discretion of Congress to submit this application to the people of the other states, with whom would rest the responsibility of its acceptance or rejection. As late as March 27, I86I, this paper argued that the Union, no longer filling the needs of the times, was about to be cast aside; that separate, peaceful existence of the sections was preferable to a Union which was unsatisfactory to one and retarded the progress of the other.

On January 3 Ist, the Commercial published an editorial, the authorship of which was ascribed to Chase, in which it was maintained that the unanimity of the people of the North for the preservation of the Federal Union existed no longer; that a revolution in public sentiment had been accomplished within the past sixty days, caused by the almost universal endorsement given by the border states to the inadmissible demands of the cotton states coupled with menaces of disunion. It held the Crittenden compromise an impossibility. "Those who voted for Mr. Lincoln cannot consent that his election shall be made the pretext for the amendment of the Constitution so as to defeat the very purpose they had in voting for him." Warning the southerners that the Union could not be constructed on any 
basis they might dictate, it was in favor of calling a convention of all the states to release the disaffected members and give peaceable secession a fair trial. ${ }^{1}$

The Press placed its argument for secession on economic grounds, holding that if a small body of southern politicians could apparently, whenever it suited their convenience, throw the industrial system of the entire Union into convulsions and thus bring about national bankruptcy, it would be better for both sides to agree to an amicable severance, rather than continue together with the elements of an eternal dispute at work. It thought the trade of Cincinnati with the South would greatly increase after separation. ${ }^{2}$

The abolition organ of Giddings on the Reserve, the Ashtabula Sentinel, rejoiced that the feeling in favor of separation was increasing. Its editor, W. C. Howells, writing to his paper from Columbus, February 6th, said that the opinion was almost universal that there was to be a division of the Union, and that public opinion was adapting itself to the idea. In another letter a week later, in commenting on the attitude of the Cincinnati papers, he said:

It is really surprising now to see how generally the public and private expression of the people of the border is in favor of peaceable separation. Its entire practicability is demonstrated to a large portion of the thinkers of the country, while the idea of coercing or fighting them to make them stay in, is looked upon as ridiculous.

The Democrats of the state, following the opinion of President Buchanan, held that while a state could not be coerced, it could not secede from the Union; that the two sections could not exist separately and that the Abolitionists, rather than the southern leaders, were responsible for

${ }^{1} C f$. also editorial of February ist for a similar expression.

${ }^{2}$ Editorials, January 5th and February 4th, I86I. 
the trouble. The first official action on the matter was taken in a convention held in January for the purpose of reconstructing the party. It had been suggested late in the year that the Breckinridge Democrats meet in convention on January 8th for the purpose of nominating a state ticket, but the idea was abandoned in the hope that concessions, such as would preserve the Constitution and the Union, would be made on all sides and thus render separate political action unnecessary. This decision was followed by a call issued by the Douglas central committee, for the Democracy to meet on January $23 \mathrm{~d}$, " for the purpose of consulting together on the alarming condition of the country, as well as to adopt such a line of policy as they may deem best for the perpetuity of our Government and the prosperity of our people." An invitation to attend was extended to the whole body of the Democracy without distinction of faction.

The real object of the convention was made apparent in its proceedings. The factions of the party were to be united on the platform of a compromise with the South, and that issue was to be forced on the Republicans. The proposition of the Border State committee, ${ }^{1}$ which was similar in its essential features to the Crittenden compromise, had just been announced, and it was made the basis of the discussions. Jewett, in his speech as presiding officer, held it to be a measure that sacrificed no principle, and declared with much earnestness that if Congress and the state legislatures refused to submit it to the people, the Republicans must fight the battles themselves. He would never consent to meet his fellow countrymen in arms. The resolutions adopted, credited the Democrats of Ohio with having " uniformly shown devotion to the Union, allegiance to the Constitution, obedience to the Federal laws and regard

${ }^{1} \mathrm{McPherson}$, History of the Rebellion, p. 73. 
for the interests of their sister States," and while they would accept with joy the Crittenden compromise or the Border State proposition or any other settlement honorable to all, which could be effected by conciliation and compromise, yet they believed that the questions which were disturbing the country were of such a character that a national convention should be called to propose amendments to the Constitution, and that the General Assembly should be memorialized to make application to Congress to call such a convention. The most conspicuous of the resolutions was the last, which recited

that the two hundred thousand Democrats of Ohio send to the people of the United States, both North and South, greeting; and when the people of the North shall have fulfilled their duties to the Constitution and the South, then-and not until then-will it be proper for them to take into consideration the question of the right and propriety of coercion.

This resolution was the cause of much discussion in the convention. As originally reported by the committee, the last part read:

then, and not until then, will it be proper for them to take into consideration the doctrine of the right of the coercion of a State; and then, and not until then, should they attempt to put down the alleged right of secession by the alleged right of coercion.

The conservative element in the convention opposed this form because it would commit the party to the right of secession and against the right of the government to enforce the law. After a spirited debate, the resolution was modified as adopted. Even so, it was violently attacked in several of the Douglas papers, the editors declaring that the party had been sold out to the Breckinridge faction, and 
some refusing to endorse the work of the convention. The party leaders, however, defended the resolution; even Tod, who was soon to head the new Union ticket, declared that if the Republicans attempted to cross the Ohio for the purpose of coercing the South, they would find the two hundred thousand Democrats in front of them. ${ }^{1}$.

With the adoption of this platform, the separate existof the Breckinridge wing of the party in Ohio came to an end, and its organ, the Cleveland National Democrat, suspended publication. The issue as drawn was that of compromise with the South, and on this the party as an organization stood consistently throughout the war period.

While the Democracy of the state thus formulated its platform in convention, that of the Republicans was to be the subject of a strenuous discussion in the adjourned session of the legislature which convened on January 7 th. By that time the doctrine of peaceable secession was losing ground and the question of compromise was uppermost. In Congress the Senate Committee of Thirteen, to which the Crittenden propositions had been referred, had already reported its failure to agree upon it or any other plan of adjustment, while the House Committee of Thirty-three was still at work. The conservative members of both branches were urging the removal of the causes of southern grievances, and in the House they were able to secure the passage on December 17 th of a resolution earnestly requesting the repeal of the Personal Liberty laws. A few days later a caucus of seven governors, including Governor Dennison, was held at New York City at which they agreed to recommend to their legislatures "the unconditional and early repeal " of these laws. ${ }^{2}$

In his annual message, the governor set forth a powerful

${ }^{1} \mathrm{~J}$. D. Cox, Military Reminiscences, vol. i, p. 4.

${ }^{2}$ Rhodes, History of the United States, vol. iii, p. 252. 
argument in support of the authority of the national government to maintain itself and against the right of secession. He was willing to concede, however, that the "discontents which have grown up between the States may and ought to be reconciled", and held that if the clauses of the Fugitive Slave law, "offensive and derogatory to those who are required to execute it, be repealed, there is no doubt the personal liberty laws which obstruct its proper execution, if any such there be, passed from whatever motive, would be repealed or essentially modified." This, he thought, should be done since the obnoxious features of the Fugitive Slave law were inserted at the instigation of those who were not interested in its execution and who were plotting to defeat it, while the states really wronged by the legislation of the free states were loyal to the Union and were not urging their wrongs to overthrow it. $\mathrm{He}$ also reviewed his action on the extradition cases of the preceding year, giving the same reasons which had been given by the attorney-general for his refusal to surrender the fugitives. Had he been clothed with the legal authority, he maintained, he would have promptly surrendered the accused parties, but his sense of duty together with the practices of the department did not permit him to do so. "The legislative power vested in the General Assembly," he held, "comprehends an authority to provide for the surrender of fugitives from justice in cases not covered by the Federal Constitution." This was the consideration which prompted him to lay the matter before that body. ${ }^{1}$

The consideration of compromise measures was begun as soon as the Assembly was organized. In the House, the Democrats, without waitng for the governor's message, offered resolutions endorsing the Crittenden compromise,

${ }^{1}$ Executive Documents, r86o, pt. i, pp. 554 et seq. 
and presented a bill for the repeal of the second section of the kidnapping act of April I7, I857. ${ }^{1}$ This section, as already noted, ${ }^{2}$ provided a penalty for the kidnapping of any black or mulatto, and forbade the removal of any such person from the state without first taking him "before the court, judge or commissioner of the proper circuit, district or county having jurisdiction according to the laws of the United States," and there establishing by proof, according to those laws, property in such person. The bill was referred to the committee on judiciary for consideration.

During the early days of the session, both parties labored in caucus to unite their various elements on some proposition for adjusting the difficulties with the South. While the Republicans were unsuccessful for the time being, the Democrats agreed to support resolutions embodying the compromise that had been prepared by a committee made up of Senators and Representatives from the border states. This proposition recommended the repeal of all Personal Liberty laws; an efficient amendment of the Fugitive Slave law which would prevent kidnapping and equalize the fees of commissioners before whom fugitives were brought; an amendment to the Constitution prohibiting interference by Congress with slavery in the states or its abolition in places under Federal jurisdiction without the consent of the states in which such places were located; the prohibition of interference with inter-state slave trade, and the perpetual prohibition of the African slave trade; the extension of the line $36^{\circ} 30^{\prime}$ across the continent as the dividing line between slavery and freedom; and the admission to statehood of any territory, having an area of 60,000 square miles and containing sufficient population for

${ }^{1}$ House Journal, 1861, pp. 4 and 6.

${ }^{2}$ Supra, p. $2 \mathrm{r}$. 
one member of Congress, with or without slavery as its constitution might determine. ${ }^{1}$ These resolutions were offered in the House on January 8th.

The House also proceeded to a consideration of the matter in committee of the whole. The kidnapping bills which had been postponed during the first session ${ }^{2}$ were brought up again for discussion. On the second day of the session, the Baldwin measure was reported to the House with a recommendation for indefinite postponement, and this was voted, fifty-nine to thirty-one, against the radicals. On the next day a motion to excuse the committee from further consideration of the Senate bill was carried, but another one to postpone was not put to vote owing to the determined effort of the radicals to have the bill referred to the committee on judiciary. ${ }^{3}$ Both branches adopted resolutions ${ }^{4}$ instructing their judiciary committees to examine the statutes of the state and report whether or not there were any acts in force which conflicted with the Constitution and laws of the United States, and, the House added, with the Constitution of the state, and to report at as early a day as possible.

After strenuous efforts the Republicans in caucus finally agreed upon a set of resolutions which were drafted by a caucus committee representing all shades of opinion both conservative and radical, and they were offered in the Senate, January I2th, by Harrison. They declared as follows :

(I) The people of Ohio believe that the preservation of

${ }^{1}$ McPherson, History of the Rebellion, p. 73. House Journal, p. I2.

${ }^{2}$ Cf. supra, p. 32.

${ }^{3}$ House Journal, r86r, pp. 14 and 23.

${ }^{4}$ In the House Jan. 9th, House Journal, p. 21. In the Senate Jan. I Ith, Senate Journal, p. I6. 
the government is essential to the peace, prosperity and safety of the American people.

(2) The general government cannot permit the secession of any state without violating the bond and compact of Union.

(3) The power of the national government must be maintained and the laws of Congress enforced in the states and territories until their repeal by Congress or until they are declared unconstitutional. All attempts by state authority to nullify the Constitution and laws of Congress or resist their execution are destructive of the wisest government in the world.

(4) The people of Ohio are opposed to meddling with the internal affairs of other states.

(5) The people of Ohio will fulfill in good faith all their obligations under the Constitution of the United States, and demand the same of every state in the Union.

(6) It is incumbent upon any states having enactments on their statute books conflicting with or rendering less efficient the Constitution or laws of the United States to repeal them.

(7) All Union-loving citizens who have labored to withhold their states from secession are entitled to the gratitude of the whole American people.

(8) The entire power and resources of Ohio are pledged for the maintenance, under strict subordination to the civil authority, of the Constitution and laws of the general government, by whomsoever administered.

(9) Copies of the resolutions should be sent to the President, the two houses of Congress and the governors of all the states. ${ }^{1}$

These resolutions were adopted by a unanimous vote,

${ }^{1}$ Senate Journal, 186r, p. 19. 
the senators pledging themselves to join hands in an effort to restore peace and maintain the Union. The House, which had adjourned for the day, was called together and the journal changed, against the signed protest of fourteen Democratic members, to indicate that it had only taken a recess. The resolutions were offered, and some attempts were made by the Democrats to amend them by introducing a sentiment adverse to the coercion of those states that had declared their allegiance to the Union dissolved. The attempts failed, however, and after a motion to postpone had been defeated by a strict party vote, the resolutions were voted upon separately and carried, five unanimously and the others ${ }^{1}$ against the opposition of a few of the extreme Democrats.

By this action, Ohio was placed on record as favoring the repeal of whatever state legislation tended to render the Fugitive Slave law ineffective, and thus removing any grievance the South might have on that score. Other states adopted the same policy, and by the end of January most of these laws throughout the North had been taken from the statute books. ${ }^{2}$ While the tone of the resolutions was too conservative to satisfy some of the radicals, yet they acquiesced in them for the time being in the interest of harmony. The differences between the two factions of the party were not by any means adjusted, however, and much time was still to be devoted to the discussion of the questions at issue.

On the next day after the adoption of the resolutions, the Senate bill to prevent kidnapping was again taken up for discussion. Fourteen radicals still held out for the immediate passage of such a law, and the discussion turned on the

'The Ist, 2d, 8th, and 9th. House Journal, i86r, p. 40.

${ }^{2}$ Rhodes, History of the United States, vol. iii, p. 253. 
question whether the state should maintain a position of non-action or manifest a disposition to conciliate the South. The bill was finally referred to the committee on judiciary by vote of fifty-two to forty-one. ${ }^{1}$ When it was reported two days later with a recommendation of indefinite postponement, this was carried by vote of seventy-one to twentysix. $^{2}$ Twenty-seven Republicans who had cast their ballot to refer on the first vote changed on the second, and all but five of these came from the southern part of the state.

On the matter of unconstitutional legislation, the Senate committee reported on January $25^{\text {th }}$, that the second section of the act of April I7, 1857, was the only law which was in conflict with the Constitution of the United States, and presented a bill for its repeal. After some days of discussion, this was referred back to the committee with instructions to report in writing. ${ }^{3}$ The committee of the House made its report, February $7^{\text {th, }}$, proposing a substitute which would limit the provisions of the section in question to free persons and omit the clause requiring proof before a court. In the majority report, signed by the conservatives and Democrats, the reasons stated were that the substitute would provide ample protection to all free persons in Ohio, and would remove the feature of the act which was held to be unconstitutional, since the United States Supreme Court had decided in the case of Prigg vs. Pennsylvania ${ }^{4}$ that the owner of a slave had an unqualified right to his property which was not impaired by flight, and that no state law could interfere to control or restrain this right. The minority of the committee, representing the radicals, presented a report denying that the law in question was in conflict with the Constitution; if it were, then

${ }^{1}$ House Journal, i86I, p. 48.

${ }^{3}$ Senate Journal, i86I, p. I19.
'Ibid., p. 55.

4U. S. Reports, I6 Peters, p. 540. 
the Federal laws of 1793 and I850, which required the owner to prove his property and which had been held constitutional, must be repugnant to the fundamental law. The Constitution, this report held, was

no limitation upon the State to exercise its own police regulations, nor does it give any extra-territorial force to the laws of the State from whence the slave may have fled, further than it holds the obligation on the part of the slave to render service to the master valid.

It nowhere provided that reasonable delay, to determine a question in controversy, could not be had in allowing the return of a slave. ${ }^{1}$ The bill and reports were laid on the table, and no further action was taken on the matter in either house.

The Democrats not only gave their support to all measures for the abrogation of the Personal Liberty laws, but also urged the enactment of positive legislation to compel the governor to surrender fugitives from the southern states. Acting on Dennison's assertion that, "the legislative power of the State vested in the General Assembly comprehends an authority to provide for the surrender of fugitives from justice in cases not covered by the Federal Constitution," they took up the matter at once, and on the second day of the session a bill was introduced in the House providing that any person charged with the commission of a criminal offense against the laws of any state and fleeing to Ohio, should be delivered up to the governor of the state from which he fled, whether the act charged was contrary to the laws of Ohio or not. ${ }^{2}$ A second bill, introduced a few days later, made it a misdemeanor for a person

'Reports in House Journal, I861, App., p. 9.

${ }^{2}$ House Journal, 1861, p. 10. 
to harbor a runaway slave or assist him to escape. ${ }^{1}$ A third presented the most radical Democratic views, in providing that any person knowingly aiding a fugitive slave to escape should be guilty of a misdemeanor and held to pay the value of the slave to the county in which the offense was committed in addition to serving a prison sentence, while the county in turn was to be held responsible to the master for the value of the slave. ${ }^{2}$

These bills were all referred to the judiciary committee, which reported, February Ist, recommending their indefinite postponement. The reasons given were the same as those advanced in the report of February 7 th, that the Constitution required Congress to enact necessary laws for the return of fugitives from service, and since the Supreme Court had decided that Congress had exclusive jurisdiction in the matter, the enactment of a state law would only produce conflicts between the state and the Federal courts. ${ }^{3}$

The first two bills were laid on the table while the third precipitated a six days' discussion which ranged over the whole question of slavery. The conservative doctrine had been set forth in a series of resolutions offered in the House, February 6th, calling on Congress to pass an act more specifically defining for what offenses a fugitive should be delivered up and the mode in which the application should be made. ${ }^{4}$ The Democrats took the position that the return of fugitives was a matter for the state to control, and that it was due the South that some law such as had been suggested should be enacted. The radicals were for sustaining the governor's action, and held that the discussion of the subject was at least permanent, since the Lago case was still pending in the Supreme Court. Finally, on February

\footnotetext{
${ }^{1}$ House Journal, i86i, p. 107.

${ }^{2}$ Ibid., p. I65.

${ }^{3}$ Ibid., p. 2 I6.

${ }^{4}$ Ibid., p. 142 .
} 
27th, the debate was closed by the House refusing to engross the bill.

In the Senate things went more quietly in regard to all these various matters. A bill was introduced, January 26 th, by one of the conservatives making it a crime for a person to assist anyone owing service in another state to escape. $^{1}$ The discussion showed a hopeless difference of opinion, and the bill was finally referred to a select committee which never reported it.

The most noted contest of the session between the conservatives and radicals, came over the selection of delegates to the Peace Conference at Washington. In a message, January $25^{\text {th }}$, Governor Dennison transmitted to the Senate the resolution adopted by the Virginia legislature proposing a conference to meet at the Capital, February $4^{\text {th, }}$ to make an effort to adjust matters on the basis of the Crittenden compromise. After reciting the proposals submitted, the governor proceeded to say that he thought the terms of adjustment were inadmissible, and regretted that all encouragement of reliance on the Constitution as it then was, had been omitted. ${ }^{2}$

On the receipt of the message, Monroe, cautioning the Senate against haste, moved to lay the matter on the table, while Harrison urged immediate action, holding that after the efforts of eminent men of the border states in Congress to preserve the Union, Ohio should omit no effort to meet her sister states in an attempt to restore peace to the distracted country. The motion prevailed, however, and the Virginia resolutions were referred to the committee on Federal relations. ${ }^{3}$ When the communication was received in the House, Nigh, one of the conservative members, offered a joint resolution providing that Thomas Ewing, Joseph R.

${ }^{1}$ Senate Journal, p. 50.

${ }^{2}$ Ibid., p. 47 .

Ibid., p. 51 . 
Swan, Daniel R. Tilden, David Tod and William S. Groesbeck be chosen as commissioners to represent Ohio. ${ }^{1}$ This was laid over and taken up for discussion two days later by a majority of one vote. A spirited debate followed between the two factions, the conservatives urging that commissioners chosen by the legislature would be more kindly received by the border states than any appointed by the governor who had assumed such a hostile attitude toward them, while the radicals held that since the Democrats had said in their convention a week before that the contest must be between the Republican party and the South, they could have no right to membership on the commission. This latter faction also argued for postponing the conference until April, on the ground that the time was too short for all of the states to select representatives, but their real purpose was to delay it until after the inauguration of Lincoln. Above all, they objected to the Crittenden compromise as a basis of adjustment.

In a stormy Republican caucus, in the course of which the radicals served notice on the conservatives that they must act with the Republican majority on all party measures or quit the Republican camp, a project was adopted by no means unanimously, and offered in the House, as a substitute for the joint resolution. It accepted the invitation, directed the governor to appoint five commissioners and expressed a preference for April 4th as the date on which the conference should meet. It further stated:

That while we are not prepared to assent to the terms of settlement proposed by Virginia, and are fully satisfied that the Constitution of the United States as it is, if fairly interpreted and obeyed by all sections of the country, contains ample provision within itself for the correction of all evils complained

'House Journal, p. I02. The first three of these were conservatives and the others were Democrats. 
of, yet a disposition to reciprocate the patriotic spirit of a sister State and a sincere desire to have harmoniously adjusted all differences existing between us, induces us to favor the appointment of commissioners as requested.

This was met by the conservatives with a counter substitute which provided that Thomas Ewing, Reuben Hitchcock, William S. Groesbeck, John McLean and Joseph R. Swan be constituted commissioners, and held it to be unwise and inexpedient to embarrass them with any expression of opinion as to the adjustment of the existing differences. It however left April 4th as the date. This substitute was carried by the Democrats and conservatives, and the resolution as amended was then adopted. ${ }^{1}$

This defeat was keenly felt by the radicals. In commenting on it the Cleveland Leader said: "It is humiliating that with a Republican majority of 30,000 votes, Ohio has not a Republican majority in her legislature." 2 The feeling was intensified by the tone of Governor Letcher's message in transmitting the resolutions of January I2th to his legislature, in which he said that such resolutions sent to the slave-holding states could only excite resentment and inflame prejudice, and since the legislature of Virginia had expressed its opinion on the doctrine of coercion, they could be regarded in no other light than as a threat against all those states which recognized the right of secession. ${ }^{3}$ An attempt was made to get a reconsideration of the vote, on the ground that the resolution as adopted was a tacit admission that Ohio would compromise on the basis indicated by Virginia, but it failed.

In the Senate, Harrison, from the committee on Federal

1 House Journal, i861, p. I09.

${ }^{2}$ Editorial, January 3 Ist.

${ }^{3}$ Cincinnati Commercial, January 28 th. 
relations, reported a substitute which he explained was a compromise between the two factions in the committee. It proposed that the commissioners be appointed by the governor with the consent of the Senate, and that no instructions be given. ${ }^{1}$ A minority report was presented embodying the Republican caucus resolutions. Both reports were referred back to the committee with instructions to endeavor to agree on some proposition. On January 3 oth a substitute was reported from this committee, to which the House resolutions had in the meantime been referred, providing that the commissioners be chosen by joint convention of the two houses and incorporating the caucus instructions. $^{2}$ An amendment giving the power of appointment to the governor was carried by the deciding vote of the presiding officer, and the substitute was then adopted. It was sent back to the House where it was pushed through by a vote of fifty-two to forty-five, under great pressure from the radical leaders. ${ }^{3}$

Thus, as the resolutions were finally adopted, the radicals won on the method of appointment and the instructions, while the date was left as originally fixed. On the day after their adoption provision was made for two additional members of the commission. As finally appointed, it consisted of S. P. Chase and Reuben Hitchcock, radicals; Thomas Ewing, Sr., Franklin T. Backus and Valentine B. Horton, conservatives; John C. Wright, an old line Whig; and William S. Groesbeck, a Democrat. During the session of the conference Wright died, and the governor appointed his attorney-general, C. P. Walcott, an intense radical and the author of the opinions on the extradition cases, to the

\footnotetext{
1 Senate Journal, p. 55.
}

${ }^{2}$ Ibid., p. 57.

${ }^{3}$ House Journal, p. I2I. Chase was present at the session in the interest of the measure. 
vacancy. There was much opposition to this appointment, the Senate confirming it by the narrow majority of one.

The contest on these various matters was keen and the contestants pretty evenly matched, but as the session advanced the spirit of conciliation gained ground. The question of calling a convention of the states had been brought up, January I Ith, by Key, one of the Democratic senators from Hamilton county, ${ }^{1}$ and on January 24 th the president of the Senate submitted the resolutions of the Democratic convention on that subject. Both propositions. were referred to the committee on Federal relations, and no action was taken until March 7 th, when the Key resolutions were reported back without recommendation. ${ }^{2}$ In the discussion, their author urged their adoption in the interest of compromise, and especially since similar resolutions had been adopted by the legislatures of Kentucky, Illinois, and Wisconsin. Monroe asked that action be delayed until his side could be brought together. He asserted that a few months before they would all have opposed such a proposal, but that their views were changing. On his motion, consideration was postponed for a week, when the resolutions were adopted with only five dissenting votes. ${ }^{3}$ In the House they were carried against the votes of twenty-two Republicans, half of whom were from the Reserve. ${ }^{4}$

On March 23d, the proposals for compromise which had been agreed upon by the Peace Conference and rejected by both houses of Congress, were offered in the House by one of the conservatives and tabled. ${ }^{5}$ Two days later, the governor transmitted to the Senate the Corwin Amendment, which had been passed by Congress a few days before. This proposed to add to the Federal Constitution an article

\footnotetext{
${ }^{1}$ Senate Journal, r861, p. $15 . \quad{ }^{2}$ Ibid., p. $155 . \quad{ }^{3}$ Ibid., p. 177.

${ }^{4}$ House Journal, p. 346 . $\quad{ }^{5}$ Ibid., p. 366.
} 
that would forbid Congress to abolish or interfere with the domestic institutions of any state. ${ }^{1}$ A resolution of ratification was offered, but action was delayed until April I7th, when it was adopted against the votes of the Reserve members. $^{2}$ In the House, it was not taken up until after the

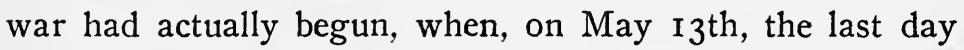
of the session, it was adopted by a majority of four votes. ${ }^{3}$ Only one other state, Maryland, ratified the Amendment.

In March, after the United States Supreme Court had announced its decision in the Lago case, the governor was called upon by the House for a copy of the decision, and an attempt was made by the Democrats to bring up again the question of returning fugitives. A bill was introduced making it compulsory on the governor to deliver up a fugitive from justice charged with an offense considered as a crime by the laws of the state from which he fled. This was referred to its author as a select committee and reported by him on April I6th. ${ }^{4} \mathrm{He}$ advocated its passage because of the governor's expression in his message, and because the Supreme Court had held in its decision that while Congress could not impose a Federal duty on the officers of a state, yet when called upon to perform such a duty, it would be an act of good faith on their part to comply. The passage of the bill would, he thought, do much to relieve Governor Dennison and the people of the state from the censure and hostility manifested toward them, and would tend in great measure to "restore that good understanding and mutual comity which formerly existed between us and our sister States.” The bill and report were laid on the table, and no further action was taken.

The only legislation on the question of the negro that

${ }^{1}$ McPherson, History of the Rebellion, p. 58.

${ }^{2}$ Senate Journal, p. 289 .

${ }^{3}$ House Journal, p. 652.

'Ibid., p. 571, and App., p. 87. 
reached fruition during the session was an act to prevent intermarriage between the two races. ${ }^{1}$ The Democrats kept the question of immigration before the two houses, but could not bring the conservatives to act with them on any measure to prohibit it.

Another contest of some importance occurred over the acceptance of a request made by the Secretary of the Treasury, February $4^{\text {th, that }}$ Ohio lend her credit to the national government to guarantee the repayment of United States bonds to the amount of the surplus revenue which the state had received in the distribution of $1836 .^{2}$ In the Senate there was little opposition to granting this, and a bill was at once passed under a suspension of the rules, ${ }^{3}$ but in the House it was violently opposed by some of the Democrats " as unwise, inexpedient and a flagrant violation of the Constitution of our State." " After considerable discussion and several attempts at amendment, it was finally passed, February I4th, with twenty-five Democrats still opposing it. ${ }^{5}$ Similar requests were made to New York, Pennsylvania and Massachusetts, and granted. The proceeding was unique, the United States asking the states to guarantee the payment of her bonds; however, as it worked out the endorsement was not needed, and the states were not called upon to make good their guarantee.

After the entrance of Chase into the Cabinet, a contest began among those who had Senatorial aspirations, for his place. Dennison and Sherman were prominent candidates,

${ }^{1}$ Laws of Ohio, vol. Iviii, p. 6.

${ }^{2}$ Senate Journal, 1861, p. 93.

${ }^{3}$ Ibid., p. 94 .

'House Journal, pp. I80 and 204. The state Constitution, art. viii, sec. 4, says: "The credit of the State shall not, in any manner, be given or loaned to, or in aid of any individual, association or corporation whatever."

${ }^{5}$ House Journal, p. I76. 
as well as the conservatives, Horton, Schenck and Delano. In a Republican caucus held March I4th, thirty-two ballots were taken, in two of which Dennison received a majority, but both times there were more votes cast than members of the caucus. The Reserve was strong for him, though the Cleveland Leader advocated the choice of a man from the southern part of the state, in order that Wade's chances for reëlection the next year might not be jeopardized. Horton was a promising candidate, but his attitude on the measures discussed in the Peace Conference was too conservative to win much support from the radicals. On March 2oth, Sherman was nominated on the seventy-eighth ballot, and he was elected in joint convention of the two houses the next day. ${ }^{1}$

The legislature, at this session, during the months preceding the outbreak of the war, as well as after hostilities had begun, was compelled to deal with the most momentous problems of the period. The conflict which raged within the state between the different political factions was little less strenuous than that which was being carried on at the national capital. But as the contest went on, the radical platform of opposition to the Fugitive Slave law and no compromise with the South lost many of its supporters, and the policy of conciliation grew in favor. Public opinion in Ohio as throughout the North was inclining toward compromise, and this had its effect on the legislature. The resolutions of January $\mathrm{I} 2$ th were conservative, and while they did not express the sentiment of the radicals at the time of their adoption, this element of the party; by the beginning of April, had tempered its views to conform to them. True, the law of 1857 was not repealed, but there was a question as to whether or not it was in conflict with

${ }^{1}$ Cincinnati Commercial, March 22d. Sherman, Recollections, vol. i, p. 233 . 
the Constitution, and the fact that there was little desire outside of the Reserve to reënact the Personal Liberty laws which the Democratic legislature had repealed, shows a great change from the attitude taken in the defeat of Judge Swan and the renomination of Judge Brinkerhoff. Again, though the conservatives were not quite able to take the appointment of the Peace Commissioners out of the governor's hands, and thus administer a rebuke for his action on the extradition cases, yet it was only by the greatest pressure from the party leaders that the caucus resolutions were driven through the lower house. The fact that, so far as the great questions at issue were concerned, the statute book remained the same as it had been left by the preceding Democratic legislature, indicates the change which was developing in political feeling in the state. The Ohio Republicans, it is true, followed the lead of Congress, and advanced beyond it only in adopting a resolution, which Congress refused to pass, calling for a national convention; but their willingness to ratify the Corwin Amendment shows that they were alert to every suggestion for compromising the difficulties with the South.

The result of the spring elections indicated the change of sentiment among the people at large. The reunited Democrats, supported by the Bell men and by many of the conservatives, carried Cincinnati, Cleveland, Columbus, Sandusky and Toledo, the five largest cities of the state. In Cleveland, these factions combined on a "Union" ticket, the idea of which originated with the Plain Dealer. Commercial interests and a growing feeling that the Abolitionists were to blame for the existing troubles, worked to keep the state friendly to her southern neighbors, and had not the South begun hostilities, it is probable that Ohio would have gone with the conservatives or even with the Democrats in the fall elections. 


\section{CHAPTER II}

The Union Party in Ohio; Organization and Work

\section{GENESIS OF THE UNION PARTY}

With the firing upon Fort Sumter, the beginning of actual civil war, Ohio was called upon to turn from her consideration of compromise measures and face the new situation presented to the North. The hasty and, as it was thought, unreasonable action of the South in resorting to arms to destroy the Union left seemingly no choice. With characteristic enthusiasm Ohio, through a large majority of her people, declared herself in favor of supporting the national government in all measures looking toward the suppression of the rebellion.

Mass meetings, regardless of party, were held in various parts of the state, notably at Columbus and Cincinnati, and resolutions were adopted calling on the people to ignore party differences and unite in a generous support of the national administration. At the Cincinnati meeting, resolutions drafted by Rutherford B. Hayes, then a resident of that place, asserted that the people, without regard to party, were unanimously of the opinion that the authority of the United States, as against the rebellious citizens of the seceding and disloyal states, ought to be maintained. ${ }^{1}$ Together, Mr. Hayes and Judge Stanley Matthews, who was serving as United States Attorney for. the southern district of Ohio under appointment from President Buchanan, 
agreed that they would go into the war, Mr. Hayes writing in his diary: "I would prefer to go into it if I knew I was to die or be killed in the course of it, than to live through and after it without taking any part in it." ${ }^{1}$

Throughout the southern part of the state, public opinion advanced to the position occupied by the Cincinnati Gazette, the radical organ of southern Ohio. ${ }^{2}$ The Commercial, in answer to reflections on its peace editorials, held that, while it was an early advocate of a national convention to settle the differences upon a fair and permanent basis or to allow the cotton states to go in peace, it had never been willing to acknowledge the right of secession and, since the rebels insisted upon war, it should be prosecuted to the uttermost. ${ }^{3}$ Even the Press could claim a consistency between its earlier position in favor of peaceable secession, and a policy of war. Secession, it maintained, would not have necessitated war, and had the South harbored no designs beyond secession, she would not have made war the initiatory proceeding. The conclusion was, therefore, that the South looked beyond secession to conquest and dominion, ard hence, having chosen war, she should have it to her heart's content. ${ }^{4}$

The keynote of the events, following the outbreak of the war, was abandonment of all party feeling in the common cause of supporting the administration in putting down the rebellion which the traitors of the South had begun. This was sounded by Governor Dennison in his proclamation issued on April I 5 th, in response to Lincoln's call for

'Hayes' Diary, MS. Entry of May 10, 1861.

${ }^{2}$ Judge Simeon Nash, of the southern district, writing to Secy. Chase from Gallipolis, May 3d, said: "I think the Gazette fairly represents public opinion in southern Ohio . . . I would not have believed it possible that such a change could have occurred in so short a time." Chase Papers, MS.

${ }^{3}$ Editorial, August 19, I86r.

${ }^{4}$ Editorial, May 22, I86I. 
troops, when he said: "At such an hour, rising above all party names and party bias, resolute to maintain the freedom so dearly purchased by our fathers and to transmit it unimpaired to our posterity, let the people assert their power." 1 It was echoed in the resolutions of the mass meetings, and in the dispatch of Tod to the President, that the two hundred thousand Democrats of Ohio were ready to uphold him in crushing out treason and rebellion.

The General Assembly was still in session, when the news of the beginning of hostilities arrived, and its members were called upon to give material expression to this new sentiment. Governor Dennison, in a message, offensive to the conservative people of the state on account of its partisanship, declared that the war had been begun by the malcontents of the South for the purpose of spreading slavery into the territories where it was prohibited by law, and would be prosecuted by them to conquer and partition the country. To assist the nationa! authorities, he recommended an appropriation of not less than $\$ 450,000$ for the purpose of arming and equipping the voluntary militia, and the prompt organization and arming of the military forces of the state. $^{2}$ In the Senate this appeal met with an immediate response. A bill was introduced from the committee on finance, "to provide for the defense of the State and for the support of the Federal government against rebellion," making the appropriation asked for, and in addition providing $\$ 500,000$ for carrying into effect any requisition of the President to protect the Federal government, and \$50,$\infty 00$ as an extraordinary contingent fund, all of which was to be expended under the direction of the governor. ${ }^{3}$ This

${ }^{1}$ Executive Documents, i86r, pt. i, p. 376.

2 Ohio Statesman, April r6, I86r.

${ }^{3}$ Laws of Ohio, vol. Iviii, p. 89. 
was passed under a suspension of the rules with only one dissenting vote, ${ }^{1}$ the Democrats giving their support, not because they were especially favorable to the war policy, but because they disbelieved in secession. In the House a motion to suspend the rules failed to receive the necessary vote, a part of the Democratic members opposing it, because they wished to consult their constituents before voting. By the time the bill came up in regular course for its third reading, however, the pressure from all sides was sufficient to drive even the most conservative into line. In a series of patriotic speeches the opposition members declared that having heard from their constituencies they were ready to give their adherence. While still holding the Republicans responsible for the causes of the war and reciting their own endeavors to secure peace and compromise, they held that the South had broken faith and had committed an overt act of treason; hence there was nothing for them to do, but to vote to support the government in accordance with their oath and for the sake of Union. The bill was then passed by a unanimous vote. ${ }^{2}$

Lest the southern border of the state might become endangered, Dennison sent a communication to Governor Magoffin, of Kentucky, expressing the hope that nothing might imperil the friendly relations existing between the two states, and declaring his determination to use all his influence and authority to prevent any aggression by citizens of Ohio against the people or state of Kentucky. However, he declared that all the resources of the state would be devoted to the support of the Constitution and the laws of the United States and to the maintenance of whatever policy the general government should determine upon. In response, the Kentucky governor promised that he would ex-

\footnotetext{
${ }^{1}$ Senate Journal, i86r, p. $284 . \quad{ }^{2}$ House Journal, 1861, p. 509.
} 
ert his influence to prevent anything being done to endanger Ohio and especially, Cincinnati. A few days later, he asked the aid of Governors Dennison and Morton of Indiana, in an effort to bring about a truce between the general government and the seceded states, until the meeting of Congress in July in the hope that some way might be pointed out by that body to settle the national difficulties. Dennison replied that, believing the general government to be wholly in the right, he could see no reason for the interposition suggested, but he offered to unite with Magoffin in an appeal to the seceded states to return at once to their allegiance and thus terminate the difficulties. ${ }^{1}$ Nothing further came of the correspondence and on May 2oth Magoffin issued his famous proclamation of neutrality.

In the meantime, while these negotiations were pending, acts were passed by the legislature providing for the organization of the militia, ${ }^{2}$ appropriating $\$ 2,000,000$ for the defense of the state against invasion, and authorizing the governor to continue in the service of the state nine regiments which had volunteered but had not been called into the service of the United States. ${ }^{3}$ Other acts allowed the governor to accept seventeen new regiments to fill any requisition of the President or to repel any invasion; forbade the transportation of contraband of war through the state; provided relief for the families of the militia mustered into the service of the United States; and exempted the property of such from sale on any execution. ${ }^{4}$ Finally, a measure which had been introduced in the Senate during the early part of the session by Garfield, to define and punish treason against the state, was taken up and passed. ${ }^{5}$

${ }^{1}$ Correspondence in the Crisis, May 9, $186 \mathrm{r}$.
${ }^{2}$ Laws of Ohio, vol. lviii, p. 95.
${ }^{3}$ Ibid., p. 107.
4Ibid., pp. I13, 126, 127, 132.
${ }^{5}$ Ibid., p. I ro. 
Some objection was raised to it in the Senate, on the ground that it sought to make treason against the United States punishable in the state courts.. In the House the members from the Reserve refused to support it, because it contained a clause, making it a misdemeanor for any person within the state to set on foot any unauthorized military. expedition ${ }^{1}$ against the territory or people of any of the United States.

After enacting these measures, the General Assembly adjourned on May I $3^{\text {th, }}$ after a session lasting over four months. With the hearty approval of the people, it had apparently done everything to put the state in accord with the national administration and make for a vigorous prosecution of the war. It remained to be seen, however, whether this abandonment of party and this unanimous support of the Union would survive the first burst of enthusiasm and continue through the excitement of a political campaign.

The Plain Dealer, after its success in the spring election at Cleveland, ${ }^{2}$ continued its advocacy of a Union party and urged unity of purpose in support of the administration. ${ }^{3}$ The Cleveland Herald took up the matter and expressed the hope that the parties would combine and nominate Union men for the fall election. ${ }^{4}$ But several things came up to complicate the situation. In the hurry and excitement attending the first days of the war, many more troops were accepted by the adjutant-general than could be made use of and those who could not be provided for became impatient and angry when sent back to their homes. Governor Dennison was also accused of showing favoritism in

${ }^{1} C f$. the attitude of the Reserve on the John Brown raid resolutions, supra, p. 35.

${ }^{2}$ Cf. supra, p. 72.

${ }^{3}$ Editorial, April 23, I86r.

4 Editorial, May 3r, I86r. 
making appointments in the army and awarding contracts for supplies for the troops, and whether justly or not, he became the object of the most bitter attacks in the conservative and Democratic press. ${ }^{1}$ In any Union movement, therefore, he must necessarily be eliminated, and his supporters were loath to agree to this.

Again, the Democracy claimed to be the real Union party, with no other platform than that of preserving the Union and no sympathy for such as the Abolitionists, who sought to divide it. As the Ohio Statesman put it: "We are now as we ever have been, for the Union and the Constitution as it is. We go for maintaining both at all hazards and at every sacrifice save the sacrifice of that liberty and those rights which the Constitution and the Union were formed to secure." 2

Although there was much discussion in the press throughout the state as to the advisability of uniting all parties, there was a wide variance of opinion as to what form the movement should take. Up to the middle of the summer, there was no agreement on any plan. Special elections were held on May 28th in the seventh and thirteenth congressional districts, to choose successors to Corwin and Sherman. In Corwin's district, Harrison of Madison county, the leader of the conservatives in the upper house of the Assembly just closed, ran as an Independent, announcing that he had been called upon by men of all parties to become a Union candidate. In Sherman's district a straight Republican was nominated and elected. In June, local Democratic conventions were held in Holmes, Mercer, and Scioto counties and Democratic tickets nominated.

The matter assumed a more concrete form when on July

${ }^{1}$ The Cincinnati Commercial was the leader in these attacks.

${ }^{2}$ Editorial, May 7, I86r. 
$5^{\text {th }}$ the Democratic state central committee met and issued a call for a state convention to be held on August 7 th. An invitation was extended to all the electors of Ohio, "who are in favor of perpetuating the principles upon which our Union was founded, and are convinced that the present State and National Administrations are wholly incompetent to manage the government in its present critical condition" to participate; the conservative Union men being especially mentioned. ${ }^{1}$ This action brought down a storm of protest from the Commercial and Plain Dealer, because there was no word about vindicating the authority of the government or reëstablishing the union of the states. The Plain Dealer held that the Democracy of the state were not included in the invitation, since they had a large majority of the twohundred thousand soldiers then under arms, sustaining the constitutional government in putting down the rebellion. The call, however, had the effect of stimulating those who were championing the movement, to formulate some plan by which it might be carried out.

In an open letter such a plan was proposed by G. Volney Dorsey, a Douglas Democrat from Miami county, as follows :

Let no convention be called by the Central Committees of either of the old parties, but rather by men of both parties, and let that convention meet as a Union Convention, nominate good conservative men from the ranks of both political parties, and let there be an election as in the days when $\mathrm{Mr}$. Monroe was voted for in Ohio. ${ }^{2}$

Other plans were suggested along similar lines; all agreed that a non-partisan citizens' convention should be held, and the Plain Dealer thought the Republican state central com-

${ }^{1}$ Ohio Statesman, July 6, 186r.

Ibid., July IIth. 
mittee should make the necessary arrangements. The Republican committee of Cuyahoga county met on July 2oth and resolved to adjourn without taking any action upon the subject of calling a nominating convention, pending the action of the state committee.

With these suggestions before it, the Republican state central committee met on July $25^{\text {th }}$ and resolved that it was not at that time expedient to call a convention of the Republican party for the nomination of state officers, but that the Democratic state committee be requested to join in a call for a joint delegate convention. In the event that this invitation should not be accepted by August 9th, the executive committee was directed to issue a call to the people of the state to select delegates to a nominating convention, "to be chosen without reference to party, upon the simple basis of the maintenance of the government and the suppression of the rebellion against it." 1

The adoption of these resolutions did not bring the parties any nearer together than the previous discussion had done. The Ohio Statesman published them under the title, "Obituary", and said: "The Republican State Central Committee after a laborious and mournful session on Thursday night laid out and placed coppers on the eyes of the Republican organization. . . . It was born July I 3 th, $i 854$, deceaser' July 26th, I86r, just seven years and thirteen days old." The Statesman held that the Democratic committee had not been delegated any power to accept such an invitation. The Crisis, under the warning, "Beware of Masked Batteries," considered that the Republicans, having put the country into such a miserable plight, were now breaking into a panic

${ }^{1}$ Ohio State Journal, July 26, I86r. Ct. also August 14th for letter to Democratic committee.

${ }^{2}$ Editorial, July 27, r86r. 
and calling upon the Democrats. It asked to be excused. ${ }^{1}$ The Chicago Times contributed its advice: "We trust that neither the Democrats of Ohio nor any other State will enter into any such coalition. The "No Party" pretense of the Republican leaders and the Republican administration at Washington, has been a fraud from the beginning of the war." ${ }^{2}$

Nor was there unanimity in the ranks of the Republican party. The radical element was not enthusiastic over the project of abandoning their principles. Giddings had attended the meeting of the central committee and had warned the members against sacrificing the Chicago platform; and his organ, the Ashtabula Sentinel, called the action of the committee a very fair imitation of the Bull Run retreat. Secretary Chase had been consulted earlier in the year and had advised the holding of a Republican convention, giving recognition among the nominees to the patriotic Democratic element. $^{3}$ The Cleveland Leader, however, gave unqualified support to the movement as being best for the state.

The Plain Dealer was confident that the invitation would be accepted by the Democratic convention, when it assembled on August 7 th, and suggested that it nominate a full ticket of unexceptionable Union men, the governor and one supreme court judge to be taken from the Democratic ranks and the rest of the ticket from the Republican ranks. This arrangement, it was sure, would be acceptable to those who had proposed the union. For a platform, it suggested the Crittenden resolution, which had a few days before been adopted by the House of Representatives at Washington. ${ }^{4}$

${ }^{1}$ Editorial, August I, r861.

${ }^{2}$ Editorial, July 28th.

${ }^{3}$ Schuckers, Life of Chase, p. 275.

${ }^{4}$ This resolution asserted, (I) that the war had been forced upon the 
Most of the counties held their local conventions for selecting delegates to the Democratic convention, during the days intervening between the adoption of the resolution by the Republican committee and August 7 th. The general sentiment expressed by those who attended was unfavorable to any coalition. In several counties, attempts were made to adopt the Crittenden resolution, but in none were they successful, objection being made to the first clause, because it did not include the disunionists of the North also. The most radical resolutions were those adopted by the Butler county convention. They declared that a war for forcing any sort of government on the sovereign people of a state was neither constitutional nor practical; demanded a peaceable adjustment of all controversies between the two sections; received with abhorrence the proposal to unite with the Republicans, and urged the state committee to reject any such overture with silent contempt. ${ }^{1}$

When the delegates began to assemble in Columbus for the convention, some were rejoicing at the defeat at Bull Run, and were ready to make political capital out of the mismanagement of the War Department and the blunderings and triflings of Governor Dennison. The Breckinridge wing of the party was much in evidence, as were also many members of the Bell and Everett party. On the evening before the convention met, Mr. Crittenden addressed a large

country by the disunionists of the southern states in revolt against the constitutional government, and (2) "that this war is not waged upon our part in any spirit of oppression, nor for any purpose of conquest or subjugation, nor purpose of overthrowing or interfering with the rights or established institutions of those States; but to defend and maintain the supremacy of the Constitution and to preserve the Union with all the dignity, equality, and rights of the several States unimpaired; that as soon as these objects are accomplished the war ought to cease." McPherson, History of the Rebellion, p. 286.

${ }^{1}$ Cincinnati Gazette, August 6, 186r. 
crowd from the State House steps, urging an earnest support of the government; but there was no mistaking what the attitude of the delegates would be.

In connection with the governorship, the names of $\mathrm{H}$. J. Jewett, Stanley Matthews, Ex-Senator William Allen, George W. Morgan, George W. McCook, Thomas J. Smith, and C. L. Vallandigham were suggested, but only the first three were actually balloted on. Jewett was nominated by a large majority. For lieutenant governor, John Scott Harrison, a Know-Nothing, was nominated but later declined, refusing to be a party candidate, and John C. Marshall of Brown county, an old-line Whig, who had been very active in the canvass of the preceding year for the Democrats, was selected by the central committee in his place.

The platform declared the war to be the "natural offspring of misguided sectionalism engendered by fanatical agitators, North as well as South; and that the Democratic party ... is in no way responsible for calamities that have resulted from a departure from its doctrines, and a disregard of its warning and advice;" embodied the second part of the Crittenden resolution; recommended the calling of a national convention, "for the purpose of settling our present difficulties and restoring and preserving the Union;" denounced the corruption and extravagance in the war departments of both the state and national governments; expressed the hearty thanks of the Democracy to the volunteer soldiers; and, holding that the privilege of the writ of habeas corpus could be suspended only by Congress, denounced the late attempt of the President to suspend its privilege, as unwarranted by the Federal Constitution.

The sentiment of the resolutions was not entirely in accord with the previously expressed attitude of the candidate nominated for governor, and, therefore $\mathrm{Mr}$. Jewett, in his letter of acceptance, re-stated his views on the great issue. While 
holding that he had no terms to offer to the parties engaged in rebellion except unconditional surrender to the Union, he considered that the number of this class was small and that the great mass of the southern people were loyal to the government. These he would invite to a national convention to advise and consult on the common good. For the restoration of harmony, he would make any reasonable concession, not to pacify the traitor, but to disarm the traitor by undeceiving the betrayed. However, he would not overlook the fact that the rebellion was in the hands of those who were opposed to any reasonable and peaceful adjustment of the difficulties, short of submission to their policy and an acknowledgment of their independence; he would therefore not impair or weaken the army or government, but impart energy to both. Under no circumstances would he consent to a dissolution of the Union or consider terms of separation. ${ }^{1}$

This willingness to support the government in the war, while winning applause from those who supported the Union movement, had a tendency to put the candidate out of accord with those who had nominated him; and when after the lapse of two years he was again a candidate for the nomination, he was accused of having abandoned Democratic principles. A few days after the publication of this letter the state central committee adopted a resolution denouncing in strong terms the efforts of the President to abridge the constitutional right of free speech and a free press, by attempting the suppression of Democratic newspapers, and declared that the Democrats of Ohio would uphold their rights by all the legal and constitutional means in their power. ${ }^{2}$ By this action it was made clear that the party as an organization did not intend to put itself in sympathy

'Ohio Statesman, August 16, I86.

2 Ibid., August 28th. 
with the administration. The Plain Dealer had accepted the platform, bolstered up by Jewett's letter, as embodying the true Union spirit. When this resolution was announced, it took down the ticket and refused to support any nominee until he should declare his repudiation of the platform. ${ }^{1}$

The time allowed for the acceptance by the Democratic committee of the invitation to unite the parties having expired, the Republican executive committee did not formally carry out its instructions, to issue a call for a convention. ${ }^{2}$ But a popular call, signed by about one hundred names, appeared in the Ohio State Journal on August $\mathrm{I}_{3}$ th, inviting

all loyal citizens, of Ohio who are in favor of the maintenance of the Government, and of the vigorous and continued prosecution of the war now carried on for the suppression of the rebellion against the Government, to meet and appoint delegates to a Union Convention to be held at the city of Columbus on Thursday, the $5^{\text {th }}$ of September next.

In order that the convention might be truly representative of the whole body of voters of the state, it was suggested that it be composed of one delegate for each one thousand of the aggregate vote cast in each county at the last election.

The counties responded promptly to the call. In most cases a proposal was made by the Republican county committee for a joint convention in which the local offices should be divided evenly between the two parties, but this was refused by the Democrats of more radical tendencies, who preferred to nominate their own tickets. The result was that, in most of the counties, Union mass conventions were held, composed of the Republicans and those Democrats who were in sympathy with the war policy, in which

${ }^{1}$ Editorial, August 29, 1861.

${ }^{2}$ Cf. supra, p. 81. 
delegates were selected to attend the state convention and local tickets, made up from the ranks of both parties were nominated. In urging united action, much publicity was given in the press to the sentiment expressed by Douglas in his last speech: "Whoever is not prepared to sacrifice party organizations and platforms on the altar of his country, does not deserve the support or countenance of honest people."

Having arrived at the determination to lay aside old party principles and affiliations, there came to the members of the Union party the question of constructing a suitable platform to express the new attitude, and of selecting a a proper candidate to head the movement. Various suggestions were made as to what the platform should contain. The Cincinnati Commercial favored the adoption of the Crittenden resolution and placed this at the head of its editorial column, while the Gazette, considering that this resolution had served its purpose and, at a time when even the letter of the Constitution was being ignored, would be liable to perversion, held that the rallying cry should be: "the maintenance of the National Government according to the Constitution, and the most vigorous prosecution of the war to the suppression of the rebellion." " land Leader thought that a resolution endorsing the sentiment of the call would suffice. ${ }^{2}$

As for a candidate, it was conceded that the nomination should go to a Democrat who was in sympathy with a vigorous war policy. Several names were suggested, but before the convention assembled it was pretty generally agreed that David Tod would be the nominee. Prominent in Democratic politics for many years, he had been his party's candidate for governor in 1844 and 1846 , and had

${ }^{1}$ Editorial, May roth.

${ }^{2}$ Editorial, August 13, I86r. 
presided over the convention which nominated Douglas in I860. An ardent supporter of the vigorous prosecution of the war, he had fitted out a whole company of troops with uniforms for the service and had pledged to the President the assistance of the Democrats of the state. He had promptly repudiated the platform and ticket of the Democratic convention, because of its refusal to pledge the support of the party to the government.

On September $5^{\text {th }}$ the convention met in pursuance of the call. It was presided over by Thomas Ewing, Sr., who said in his address to the delegates: "Since I854 I have belonged to no party, but now I find myself belonging to one, the party of my country." A true Union spirit prevailed among the delegates and there was little difference of opinion as to what should be done.

The platform consisted of the whole of the Crittenden resolution, with the following added:

Resolved, in the language of the Honorable Joseph Holt, that we are "for this Union without condition, one and indivisible, now and forever; for its full preservation at any and every cost of blood and treasure, against all its assailants and against any and every compromise that may be proposed to be made under the guns of the rebels."

Tod was nominated for governor by acclamation, and the rest of the ticket was divided evenly between the two old parties. The extent to which the Reserve Republicans surrendered their partisan spirit was shown by their acquiescence in the renomination of Judge Scott, who had stood with Judge Swan in the Oberlin rescue case in declaring the Fugitive Slave law constitutional.

It was with some little reluctance, however, that the radical element came over to this new position of abandoning all Republican principles. Senator Wade, in the meeting of 
the committee on resolutions, attempted to get an endorsement of the administration inserted in the platform; afterward in the convention, John A. Bingham ${ }^{1}$ proposed a resolution pledging the people of the state "to sustain the Federal Administration in the continued and vigorous prosecution of the war until the rebellion against the Government shall be effectually subdued, to the end that the Constitution and Union may be maintained in their integrity;" but the convention refused to receive it, ${ }^{2}$ and failed even to endorse the administration of Governor Dennison.

Thus the Republican party as a state organization went out of existence, and its members for the most part affiliated with this new Union party. Some, it is true, went into it under protest, ${ }^{3}$ but, their organization gone, there was no other choice except to remain away from the polls entirely. Those who were in control of the Democratic party, on the other hand, chose to maintain its existence and to take issue with the new party on the question of a vigorous prosecution of the war.

In his letter of acceptance, Tod held that the issue presented was man's capacity for self-government. He had no doubt that it would eventually be settled to the satisfaction of all the world. He believed that the masses of the people in the South still loved the Union and would, if left untrammeled, declare for its continuance. Hence, he would

1 Then representing the 21 st district in Congress.

'Cincinnati Commercial, September 7, I86r.

${ }^{3} \mathrm{~W}$. C. Howells had persistently opposed the movement and repudiated the call for the state convention because it refused to sustain the administration or justify the course it had taken. W. T. Bascom, editor of the Xenia Torchlight, wrote to Chase, February 12, 1863; "I was not an advocate of the abandonment of the Republican party, and opposed it in a set speech in our Convention. . .. But I was voted down and went with the majority to make the best of it." Chase Papers, MS. 
argue for war eternally until the leaders "were brought to condign punishment, and their misguided followers restored to reason and brought back to a recognition of the true purposes and intentions of the Federal Government." 1

The campaign was a rather quiet one, neither party engaging in any extensive speech-making. Tod's principal speech was made at Youngstown, September 28th. In it he considered that it was folly to talk of compromise to an army of over one hundred thousand men within a few days' march of the seat of government, that measures of peace would be laughed at by them. As an example to all future traitors, the leaders of the rebellion must be put out of the way, and this done, the thousands of good and loyal men acting with them from compulsion would return to their duty. ${ }^{2}$ Jewett, in commenting on Tod's letter of acceptance, held that while both were convinced that there was a large body of loyal people in the South, Tod would visit them with the sword, while he would appeal to them as men, seeking to convince them of their error and undeceive them. ${ }^{3}$

Tod's majority in the election was 55,223 . The total vote polled, 358,79I, was over 50,000 less than that of the state election of the preceding year, and approximately the same as that of 1859 . In the Reserve alone, Tod's majority was 28,780 as against 15,527 for Dennison, yet there was a falling-off in the total vote of about 8000 , coming mostly from the Democratic ranks. The other Republican sections of the state showed a similar result, though not so marked. In most of the Democratic counties there were gains on both sides, but usually with decreased Democratic

${ }^{1}$ Ohio Statesman, September 13, 1861.

${ }^{2}$ Cincinnati Commercial, October 3, 1861 .

${ }^{3}$ Ohio Statesman, September 13, I86r. 


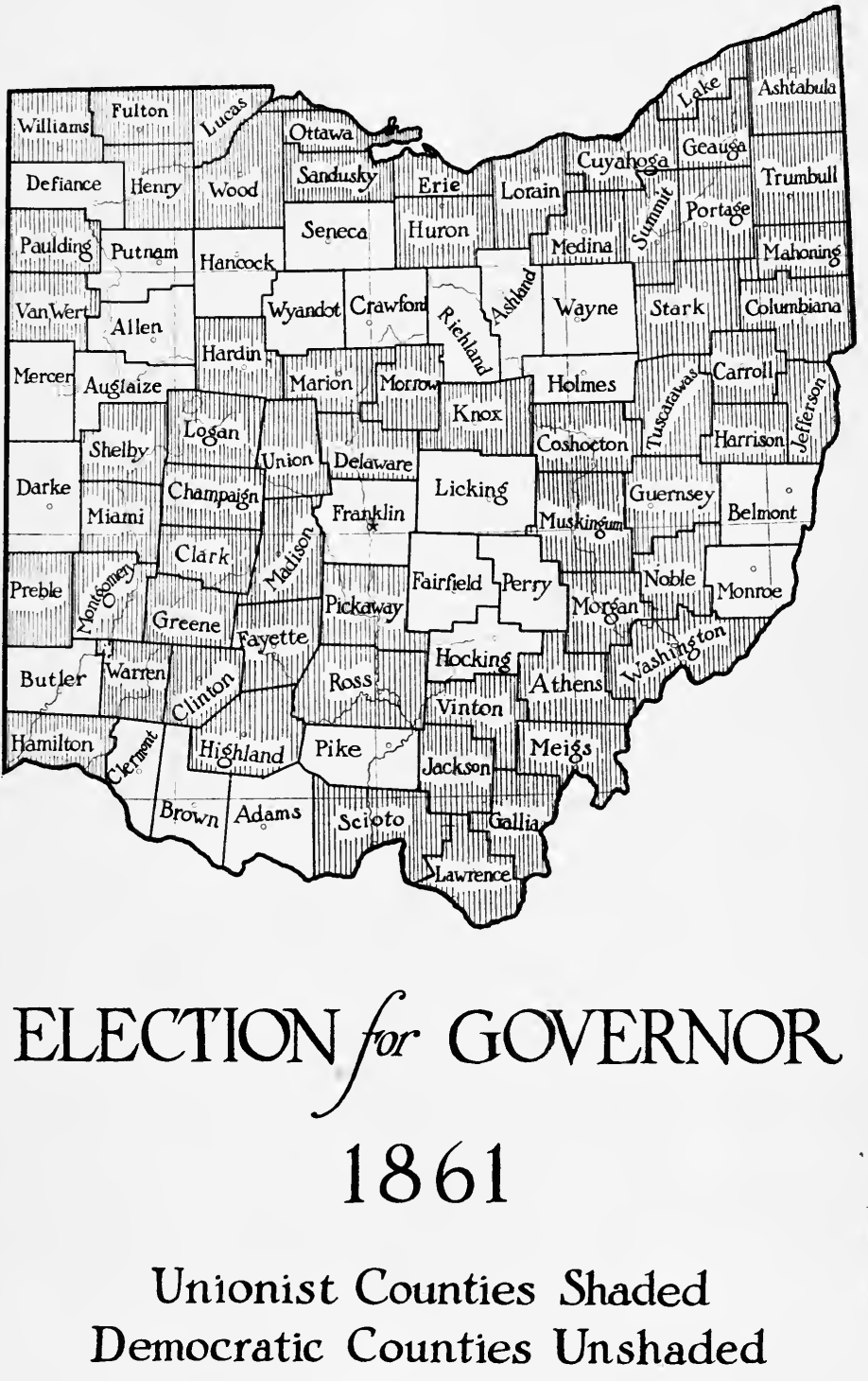



majorities, only ten counties in the whole state showing increased Democratic majorities over those of $1859,{ }^{1}$ while in fourteen Democratic counties the Unionists carried the ticket. On the legislative ticket, the Unionists elected a large majority of the members. ${ }^{2}$ Having thus obtained control of both the executive and legislative departments of the government, it remained to be seen how this new party would deal with the questions which were to arise in connection with the prosecution of the war.

\section{WORK OF THE FIRST UNION LEGISLATURE}

The General Assembly which convened on January 6, 1862, was called upon not only to give an expression on these new questions, but also to cope with some which had been left unsettled by its predecessor. During the special session of Congress which met on July 4, I86I, acts were passed imposing a direct tax on the land, laying an income $\operatorname{tax}^{3}$ and authorizing the issue of treasury notes to the extent of \$50,000,000. ${ }^{4}$ In his annual report made in December of that year, Secretary Chase recommended a national banking system which would involve the withdrawal of the notes of state banks and the issue of United States notes in their stead. Questions concerning these matters came up during the session of the legislature, together with others connected with the issuing of legal tender notes and the treatment of the slaves of those engaged in rebellion against

${ }^{1}$ These counties were: Holmes, Licking, Richland, Allen, Auglaize, Crawford, Putnam, Seneca, Wyandot, and Mercer.

${ }^{2}$ Of the ninety-seven members elected to the House, there were twenty-four Democrats, thirty-two Unionists of Democratic antecedents, thirty-two Unionists of Republican antecedents, and two Unionists of American antecedents. Of the thirty-four members elected to the Senate, there were eight Democrats, five Unionists of Democratic antecedents, and twenty-one Unionists of Republican antecedents.

${ }^{3}$ U. S. Statutes at Large, vol. xii, p. $292 . \quad{ }^{4}$ Ibid., p. 313. 
the government. It was also necessary for the state to be redistricted for congressional purposes, and a United States Senator was to be chosen to succeed Wade, whose term was to expire March 4, I863.

Governor Dennison's last message, January 7 th, was a rather long and detailed document, and of course had nothing to do with the new party policy. He criticised severely the financial project of Chase, on the grounds of impracticability and inexpediency; and opposed the income tax as being unequal, discriminating against the holders of state securities, and as operating as an additional tax on propperty charged with the direct tax. In the propositions then before Congress for the confiscation of the property of those in rebellion and the emancipation of their slaves, he saw the right solution of the slavery question. Recognizing slavery as the cause of the war, he would see the institution destroyed as the best means of ending the struggle. ${ }^{1}$

The real keynote to the new policy was naturally to be taken from the inaugural of the new executive January I6th. In this Governor Tod reiterated the sentiments he had expressed during the campaign, that the integrity of the Union must be preserved and maintained under the Constitution as it had been given by the fathers, and for that purpose, every possible support should be given to the officers of the national government. The rebellion could only be put down by bringing to condign punishment the leaders, and "satisfying their misguided followers by a firm and generous policy, that we seek, not the destruction of any of their domestic institutions, but only the maintenance and enforcement of the Constitution and laws." Ohio, he held, should bear her share of both the burden and the glory of the war, and to do this, both men and money were neces-

${ }^{1}$ Executive Documents, I86r, pt. i, p. 331. 
sary. The young men of the state by their enlistments were providing the former, and, in order that the latter might be supplied without unnecessarily burdening the people, he recommended that the state and local expenditures be reduced a third. Finally, he advised that the banks of the state be empowered for the future to pay out the notes of banks which had suspended specie payment and the treasury notes of the national government. ${ }^{1}$

Economy, then, and support of the administration in its efforts to crush the rebellion, were to be the watchwords of the party. Tod had not advanced to any new ground in regard to the end for which the war should be waged, nor did he, so long as he stood as the exponent of the new party policy.

There was a notable lack of harmony in many of the proceedings during the session. Some of those who had sat in the preceding Assembly were returned as Unionists, and it was difficult for them to forget their old party affiliations. The first discordant note was struck in the organization of the House, when the members of the new party, that were of Democratic antecedents claimed that the division of the offices and committee assignments was not equitable; and as a result a few announced their intention of standing aloof from the party and acting as independents. Likewise the Democrats caused continual disturbances by offering resolutions condemning the conduct of the war and emancipation, and by rehearsing the Crittenden resolution as to the objects of the war. ${ }^{2}$ Finally, relations became strained between Governor Tod and the Assembly, because of a certain bluntness in the expressions of his inaugural address and his impatience in regard to the passage of some measures for the welfare of the Ohio troops.

'Executive Documents, i86r, pt. i, p. 481.

'Dresel Resolutions, January Ioth, House Journal, i862, p. 23. 
Notwithstanding this, the party held together sufficiently to prevent the passage of any resolutions not in accord with its platform. Abolition sentiment was presented in a set of resolutions offered in the Senate by Monroe, who had been returned from Lorain county, endorsing the Confiscation bill of Senator Trumbull, and asserting that, when traitors were using their weapons against the life of the country, no claim which they might put forth to property in slaves or any other property, should stand in the way of the success of the Union army. ${ }^{1}$ These were tabled without discussion, as were others having as their object the forcing of an expression on the President's emancipation message of March 6th. ${ }^{2}$

The only expression of opinion regarding the war that received the concurrence of both branches, was contained in a set of resolutions offered in the House by Cory, a Unionist from Lawrence county. They declared that

the future peace of the United States and the permanency of the Government, as well as the best interests of humanity throughout the world, demand the speedy trial and summary execution of all leading conspirators in this attempt to destroy the Government, and in the name of the people of Ohio . . . we protest against the entertainment of any proposition for settlement other than unconditional submission to rightful authority and the condign punishment of the authors of the rebellion. ${ }^{3}$

These resolutions passed both branches by a unanimous vote after the Democrats failed in an attempt to have the

'See Cincinnati Commercial, January 26, 1862.

${ }^{2} \mathrm{McPherson}$, History of the Rebellion, p. 209. In this Lincoln suggested that the United States give pecuniary aid to any state which should adopt gradual abolition of slavery.

${ }^{3}$ Lazes of Ohio, vol. lix, p. I 51 . 
Abolitionists included with the rebels. A second set was passed by the lower house, declaring the duty of the government to be the prosecution of the war with all possible vigor until the power of the rebellion should have been destroyed, and expressing full confidence in the conduct of the war by the President, the War Department, and the generals of the army. ${ }^{1}$ The Democrats voted for the first sentiment but refused to endorse the second. In the Senate, the resolutions were referred to the committee on Federal relations and never reported.

An attempt was made to get a unanimous endorsement of the proposition to issue legal tender notes, while it was before Congress, but a resolution to that effect could only be passed over the united opposition of the Democratic members. $^{2}$ This vote came just at a time when there was a prospect that the Democrats and the conservative members of the Union party might unite on a Senatorial candidate, and it did much toward preventing such a combination.

Following out the governor's recommendations for retrenchment, reductions were made in state and local expenditures and appropriations were cut down until the saving was sufficient to pay all the expenses of the state during the year for war purposes, including the state's share of the Federal direct tax. The banks were given permission to receive and pay out the notes of solvent banks which had suspended specie payments and the notes of the United States. The suggestion which Governor Dennison had made in regard to the national income tax was acted upon, and a memorial was sent to Congress requesting the repeal of the measure and the substitution of a direct tax on land in its stead. ${ }^{3}$

${ }^{1}$ House Journal, 1862, p. 286.

'Ibid., p. 167.

${ }^{3}$ Laws of Ohio, vol. lix, p. I39. 
Various acts were passed having to do with the comfort and welfare of Ohio soldiers and the relief of their families. Three bills were introduced during the session with the object of extending the right of voting to troops in the field. One of these passed the Senate, and was received by the House just at the close of the session. After some discussion it was laid on the table and action postponed. ${ }^{1}$ In the politics of the year this question became prominent, and the members of the Union party had some difficulty in explaining why the measure was not enacted into law.

Much time was taken up by the Assembly in constructing the new congressional districts. Under the apportionment act of Congress, Ohio was entitled to nineteen Representatives instead of the twenty-one which she had elected during the preceding decade, and as finally adjusted the Unionists could elect a possible sixteen of these. The two changes which were to be of most importance in the ensuing fall campaign were those made in the Dayton and Columbus districts, represented respectively by Vallandigham and S. S. Cox. To the former, Warren county, which had been strongly Republican, was added, while the latter was entirely disintegrated and Franklin county was united with Madison, Clark, and Greene, all old Republican strongholds.

The most troublesome question which the Assembly inherited from its predecessor was that of excluding the negro from the state. The Democratic members, by the introduction of bills and the offering of resolutions, persisted in keeping the matter on the calendar throughout the session, while their brethren in all parts of the state waged a campaign through the press, and poured a flood of petitions into the legislative chambers, representing, according to the

${ }^{1}$ House Journal, i862, p. 679. 
Crisis, over forty thousand signers. The idea of Ohio's becoming the abiding place of the slaves set free by the western armies, with the demoralization of labor that must result, was much to be feared and abhorred. In the House, all petitions on this subject were referred to the committee on Federal relations, which made an elaborate report covering the questions of removing those already resident in the state, and of prohibiting the immigration of others. As to the first, the committee found that (I) any plan of removal would be inexpedient, in that the common rights of humanity would demand that a just compensation be made for the property which the race held within the state, which would involve too great a financial burden; and (2) it would be unconstitutional, in that no person could be transported out of the state for any offense committed thereinwhich would mean that no one could be transported for the crime of refusing to move. As to the second question, it was held that even though it might be desirable to exclude negro immigrants, this could not be done, since the Constitution of the United States guaranteed to the citizens of each state the rights and privileges of citizens of the several states, and in many of the states the negro was recognized as a citizen. The committee did not agree with the petitioners that there was any danger of competition tertween the races, since the negro, because of his low status, could perform only the most menial kinds of labor. Finally, it was confidently hoped and expected that should the government take such measures as would lead to the emancipation of many slaves, it would also provide a new home for them through some plan of colonization. ${ }^{1}$ The Assembly considered this report a sufficient answer to the petition and refused to take any further action, thus postponing the matter for another year.

${ }^{1}$ House Journal, I862, App., p. 33. 
While there was much minor dissension in the ranks of the Unionists on many questions, the election of a new United States Senator all but caused the destruction of the party. The candidates represented all shades of political opinion, from the most radical to the most conservative, the most prominent being, Wade, Chase, Dennison, R. P. Spalding of Cleveland, John A. Gurley of Cincinnati, Delano, Groesbeck, Tod, and Ewing. Most of the old radical Republican element supported Wade, while the Democratic element, which held the balance of power, ${ }^{1}$ was violently opposed to his reellection, holding that he was out of touch with the administration because of his extreme tendencies. The conservative element was divided on its candidates, Delano having the largest following.

The attitude of Chase in the matter is rather interesting. At odds with Wade because of his action in regard to the Chicago convention of $\mathrm{I} 860$, and already out of sympathy with his associates in the Cabinet, Chase was anxious to get back into the Senate, but could not rally his friends to his support. While openly announcing that he was not a candidate, he began early in the year to communicate with various members of the Assembly on the situation. ${ }^{2}$. Finding his own election to be impossible, he urged the choice of Spalding or Judge Hoadley of Cincinnati. ${ }^{3}$

The conservatives at first refused to go into caucus with the radicals, and determined to oppose any election at that session in the hope that new issues would come up later which would affect the choice. A resolution was offered

${ }^{1}$ Of the I 31 votes on joint ballot, the old Republican element had 60, the Democratic Unionists 37, the Democrats 32, while the other two were Unionists of American antecedents.

${ }^{2}$ Letter of Peter Zinn to Chase, Jan. 9th, Chase Papers, MS.

${ }^{3}$ See letters in Warden, Life of Chase, p. 408. 
in the Senate, February $4^{\text {th, }}$ calling for a joint committee to inquire into the advisability of postponing the election to the next year, in an adjourned session, but it was voted down. ${ }^{1} \quad$ A few days later a resolution to fix the time for the election was defeated by the deciding vote of the president. $^{2}$ Finally, after several unsuccessful attempts had been made to hold a caucus, seventy of the Union members were assembled on March 6th. After a stormy session, an adjournment was voted until the IIth, when thirteen ballots were taken, Wade running as high as forty-six, with Delano, his nearest competitor, reaching thirty-four. Attempts were made by the conservatives to have the caucus agree to postpone the election, but the vote stood thirty-one to fifty-two. An adjournment was then taken until the following evening.

On the next day the matter came up unexpectedly in the House. A resolution that the Assembly adjourn sine die on April 7th, had been offered on March $5^{\text {th }}$ and tabled. It came up for discussion on the I2th, when a substitute was proposed, providing for an adjourned session and the postponement of the election of a Senator until that time. This was lost, the straight Democrats voting against it, because of the clause calling for an adjourned session, but when another substitute was offered providing simply for the postponement of the election, they gave it their support and it was carried. The Senate promptly laid this resolution on the table.

When the caucus assembled on the same evening, fourteen more ballots were taken but without any result. Had it been possible for the straight Democrats and the conservatives to agree on a candidate, he could have been elected. But of the two most prominently considered,

\footnotetext{
'Senate Journal, 1862, p. 103.

${ }^{2}$ Ibid., p. 124 .
} 
Groesbeck and Ewing, the former was unsatisfactory to the Democrats because of his war sentiments, while the latter was not able to command the full support of the conservatives. In the next caucus, March Igth, eleven more ballots were taken, and a vigorous effort was made to get an adjournment until the following January. Finally, on March 27th, after several more ballots had failed to result in a nomination, the Wade men agreed to an adjournment sine die, and a resolution providing for an adjourned session was passed by the Assembly a few days later. ${ }^{1}$

\section{THE POLITICAL CAMPAIGN OF I862}

The formation of the Union party had thus transferred the political control of the state from the radical element of the old Republican party to a combination of the conservative elements of both the old parties. It was evident that this combination must continue to dictate the policy of the new organization, and the radicals soon began to long for a return to former principles. Early in the year, the Ashtabula Sentinel began to advocate such a move, holding that the only result of giving up the Republican party had been to leave the measures for which its members had labored for many years without support, and to free the President, elected on a Republican platform, from responsibility to any organized party. It proposed, therefore, the reorganization of the old party and the reaffirmation of the principles of the Philadelphia and Chicago platforms. ${ }^{2}$

This desire was inspired largely by the developments of the preceding month. Union organizations, similar to that of Ohio, had been formed in most of the northern states

${ }^{1}$ The reports given in the Ohio State Journal and Cincinnati Commercial were used in preparing this account of the proceedings.

${ }^{2}$ Editorial, January 8, 1862. 
during the summer and fall of $186 \mathrm{I},{ }^{1}$ and they had done much to remove from the campaign of that year the usual bitterness of a political contest and to present a strong front to the southern people in arms. But the course of the administration, in connection with the removal of General Fremont from his command on account of his proclamation confiscating the property of the rebels and freeing their slaves, ${ }^{2}$ had created, especially in the old Abolition centres of Ohio, a feeling of intense hostility to the President, which threatened to result in the formation of an anti-administration party among the radicals, on the platform of emancipation. ${ }^{3}$

The failure to reelect Wade to the Senate, and the substantial gains made by the Democrats in the spring elections, furnished added reasons for a return to Republican principles. In the midst of the wrangling over the Senatorial question, one of Chase's friends wrote:

From present indications, I shall not be surprised if the Union organization of Ohio had its death blow with the throes which gave it birth. It will never answer for a party, its elements are too heterogeneous to be else than discordant. Members of the Legislature of this party have neither respect for, nor influence with, each other except as they were previously associated. Straight Loco Focos control most of the Union Democrats and the hated cry "Abolitionist" makes their hair stand on end. ${ }^{4}$

The Cleveland Leader, much dissatisfied with the treatment

${ }^{1} C f$. Dunning, in the American Historical Review, October, I91o. Also, Rhodes, History of the United States, vol. iii, p. 486.

${ }^{2} \mathrm{McPh}$ erson, History of the Rebellion, p. 245.

${ }^{3}$ See Rhodes, op. cit., pp. 468-485, especially extracts from letters in foot notes.

'John H. Geiger to Chase, March I7th, Chase Papers, MS. 
of Wade, considering the approaching congressional elections in the fall, urged that a state convention be called for the purpose of nominating a straight Republican ticket, and that true Republicans be put in nomination for Representatives to Congress. ${ }^{1} \quad$ A spirited discussion was carried on by the press of the state on this question of continuing the party, and the strife became acute between the two Cleveland papers, each accusing the other of having gone into the movement for selfish purposes.

The sentiment for keeping up the Union organization prevailed, however, and a call was issued to "all loyal citizens who are in favor of the maintenance of the government, and of the vigorous and continued prosecution of the war now carried on for the suppression of the rebellion against the government." The convention met on August 2 Ist, and was completely dominated by the conservative element. The platform reaffirmed the opinion and principles of the converition held the previous September, expressed undiminished confidence in the President in his conduct of the war and pledged to his support "all the moral and physical power of the State," indorsed the conduct of the governor in his efforts tc aid the vigorous prosecution of the war, and praised the soldiers for the promptness of their enlistment and their high courage in the field. The candidates nominated were: for secretary of state, W. S. Kennon, of Belmont, a Unionist of Democratic antecedents; for supreme judge, F. T. Backus, of Cleveland; and for attorney-general, Chauncey N. Olds, of Columbus ${ }^{2}$

'Editorial, June I4, I862.

2 W. D. Bickham, then a correspondent on the Cincinnati Commercial, writing of the convention to Chase, said that the conservative Republicans and Democrats were in control of the convention. The radical candidate for supreme judge, Sutliff of Trumbull, had no chance, Ewing dictating the nomination of Backus. All the candidates for at- 
In several of the district conventions there were exciting contests between the two elements of the party, and the Senatorial question had an important influence on the nominations. In the Cleveland district, there was a contest between the Wade and Chase forces, and Spalding, the Chase candidate, was nominated. ${ }^{1}$ A third candidate was put in the field in the Toledo district by some of the conservative members of the party, who were dissatisfied with the work of the regular convention in nominating Ashley. ${ }^{2}$ In the Newark district, Delano failed to be renominated on account of the defection of his own county, which sent a delegation to the convention opposed to him and even went so far as to pass a resolution instructing the Knox county delegates in the General Assembly to cast their votes for Wade for Senator. ${ }^{3}$ In most of the other districts, conservatives were nominated.

In the meantime, the Democrats had put a ticket in the field headed by W. W. Armstrong, editor of the Tiffin Advertiser, for secretary of state, and Ranney for supreme judge, on a platform denouncing the Abolitionists for forcing party issues; opposing the emancipation policy as likely to throw upon Ohio an immense number of negroes to compete with the white laborers; condemning the violations of the Constitution by the President; and holding the refusal of the legislature to pass a law giving the soldiers in the field the right to vote to be an unjustifiable wrong to them.

torney-general were conservatives and Olds was the least objectionable. For secretary of state, it was necessary to take a Democrat, and Kennon was the only one offered. Chase Papers, MS.

${ }^{1}$ Cf. letters of R. C. Parsons to Chase, September 24th and October 6, 1862. Chase Papers, MS.

${ }^{2}$ A. S. Latty to Chase, September 10, 1862. Chase Papers, MS.

${ }^{3}$ S. G. Arnold, editor of the Newark North American, to Chase, September 19, 1862. Chase Papers, MS. 
In addition to those already discussed, various other matters came up during the year to embarrass the Union party and to affect the political campaign. The failure of the movement on Richmond in the early part of the year, led Ohio to add her voice to the general criticism of the administration and to the clamor for the removal of McClellan from his command. Subsequent affairs, culminating in the second battle of Bull Run, increased the reproaches which were being heaped upon the President and his advisors. The only success of the year in the east, the checking of Lee's aggressive movement at Antietam, furnished scant return for the men and money contributed. Enthusiasm for the war ran low, and recruits were obtained with difficulty. ${ }^{1}$

Under the first call made by the President for 300,000 men, and the later one for the same number, made at the request of the governors of the northern states, ${ }^{2}$ Ohio's quota was about 75,000 men. Half of these were, by act of Congress of July I 7 th, and the President's order of August

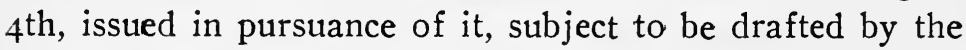
state authorities. It was Governor Tod's great desire that the quota should be filled without resorting to the draft, and through his influence unusual efforts were made to do this. In addition to proclamations, and the promise of rewards and bounties, a series of war meetings was held

${ }^{1}$ John H. Geiger wrote to Chase, July 26th: "Public sentiment is growing deep and bitter here against Mr. Lincoln because he is looked upon as an obstacle in the way of closing up the war. Men are losing all respect for him and consequently for the office he holds, and in these days of revolution God only knows what may come forth if the people get grounded in the belief that the inertia or conservatism of the President is gradually sapping the life of the Government." There are many letters in the Chase Papers, written by Ohio men, which express sentiments similar to the above.

'Lincoln, Complete Works, vol. ii, p. I94. 
throughout the state, in which Ranney, Jewett and other prominent Democrats joined with the leaders of the Union party in urging enlistment. Notwithstanding these efforts, however, the draft had to be ordered. The date for beginning was originally fixed for September Ist, but was postponed until the $15^{t h}$, and then until October Ist, when it was ordered by Governor Tod in sixty-two counties. The number then lacking to fill the quota was $12,25 \mathrm{I}$.

Again, the advance of the administration to the policy of emancipation had a powerful influence on the politics of the year. While the removal of Fremont had created mutiny in the ranks of the radicals, the conservatives, especially in the southern part of the state, were alienated by the act of Congress of July I 7 th, confiscating the estates of those in rebellion and freeing such of their slaves as should escape to another state, or take refuge within the lines of the Union army, and authorizing the President to use "as many persons of African descent as he may deem necessary and proper for the suppression of this rebellion." 1 This act increased the fear that Ohio would become the abode of the negroes as they escaped from the South; and some race riots which broke out during the summer in Cincinnati and Toledo tended to confirm this feeling. When the Proclamation of Emancipation came in the fall, its effect on the approaching elections was not difficult to foretell. To turn from a platform calling. solely for a vigorous prosecution of the war, to the indorsement of any such policy as emancipation, was something which many of the new party were not prepared to do. ${ }^{2}$

${ }^{1} \mathrm{McPherson}$, History of the Rebellion, p. 196.

${ }^{2} \mathrm{H}$. S. Bundy, Union candidate for Congress in the IIth district which included the river counties from Gallia to Brown, wrote October 3d: “The President's proclamation has come just in the nick of time to save the country perhaps, while from present appearances it will de- 
Finally, the arrest of several citizens of Ohio during the summer and fall, and their confinement without trial, laid the administration open to the charge of violating one of the fundamental rights guaranteed by the Constitution. The most prominent case was that of Dr. Edson B. Olds of Lancaster. He was arrested at his home on August I 2 th at the request of Governor Tod, on a warrant from the War Department, issued under an order of the Secretary for the arrest of persons discouraging enlistments. Having served three terms in the state legislature and three in Congress, he was again a candidate for the nomination for the latter position, but was defeated in the convention. During his preliminary campaign he was very bold in his attacks on the administration, reaching a climax in a speech delivered in his home county on July 26 th, in which he asserted that the Abolition party had brought on the war and was at that time in control of the Lincoln administration, and said that before he would enlist or before he would induce a single Democrat to enlist, he would first know what Mr. Lincoln was fighting for. He could see in a vision the ballot boxes of the country baptized in blood; and if the war was no longer to be prosecuted for the maintenance of the Constitution as it is and the restoration of the Union as it was, and was to become an Abolition war, the Democrats would refuse to volunteer and the draft would have to be resorted to in order to raise the six hundred thousand soldiers which the President had asked for. When Olds was arrested the charge as given in the warrant was disloyalty, using treasonable language and interfering with enlistments. He was taken to Fort Lafayette in New York Harbor and

feat me and every other Union candidate for Congress alcng the border. . The Democrats of the district take a position against the proclamation, including a majority of last year's Union Democrats, and unless matters improve, I will be defeated." Chase Papers, MS. 


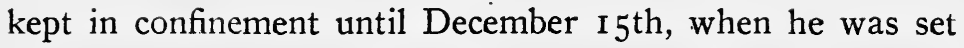
free.

John W. Kees, editor of the Circleville Watchman, was arrested on June 29th, a few days before the Democratic state convention was held, and at a time when he was being considered for the nomination for secretary of state. His editorials for some time previous had been very violent. In one he had asked: "Why don't the men of New Orleans shoot the nefarious wretch [Butler] like they would a reptile or dog?" In Canton, on October I2th, Archibald McGregor, editor of the Stark County Democrat, and Peter N. Reitzell were arrested on the charge of inciting resistance to the draft and counselling drafted men not to respond. They were taken to Camp Mansfield near by and held in confinement for about a month, when they were discharged on their taking an oath of allegiance. ${ }^{1}$

In all, eleven such arrests were made within the state. In a proclamation issued September 24th, the President gave the Executive sanction to these orders of the Secretary of War, made "all persons discouraging voluntary enlistments, resisting military drafts, or guilty of any disloyal practices, ... subject to martial law and liable to trial and punishment by courts martial or military commissicns " and suspended the writ of habeas corpus in respect to them. ${ }^{2}$

The lack of confidence in the administration in its conduct of the war, the policy of emancipation, and the arbitrary arrests, worked for the overwhelming defeat of the Union party in the Nortin in the fall elections. To these influences must be added in Ohio the strong feeling against negro immigration, which was especially aroused by the

'Report of Committee on Military Arrests, House Journal, I863, App., p. 63.

${ }^{2}$ Lincoln, Complete Works, vol. ii, p. 239. See also Rhodes, History of the U. S., vol. iv, p. 169 . 
prospect of being taxed to provide funds for compensating the slave owners for the loss of their slaves, as provided in the act freeing the slaves in the District of Columbia, and in the proposition of the President made to the border states; the failure to pass an act permitting the soldiers in the field to vote; and the dissension within the Union party, caused by the feeling that the organization had been used by the politicians for the furtherance of selfish interests.

Armstrong was elected over Kennon for secretary of state by a majority of 5,557 in a total vote of 363,070 , a slight increase over the vote of the previous year. The majorities on the state ticket reversed those of the election of I86I in twenty-one counties, fourteen of which had been Democratic in 1859. In the Democratic counties there was a decrease in the total vote with largely increased Democratic majorities, and this was true also in the southern counties which had been carried by the Unionists in I86r. Even the Reserve showed a falling-off in the Union vote. In the congressional elections, notwithstanding the redistricting of the state by the Union legislature in the early part of the year, the Democrats carried fourteen of the nineteen districts. S. S. Cox, who had waged a vigorous campaign against his opponent, was able to overcome the majority against him in his new district, but Vallandigham, although carrying the counties of his old district by an increase of five hundred votes over his majority of I860, was defeated by the vote of Warren county.

The radical papers made great efforts to protect the emancipation policy, holding that the Proclamation had not been issued long enough before the election to be made a rallying point for the Union party, or an object of concerted attack for the opposition. They ascribed the defeat to the lack of military successes and to the assumption of 
arbitrary powers by the President in the matter of political arrests. ${ }^{1}$

The charge was also made and persistently maintained by the radicals, that the defeat was due largely to the fact that, while large numbers of men of Republican antecedents had enlisted and were out of the state where they could not vote, most of the Democrats had staid at home. The facts, however, do not support this charge. ${ }^{2}$ In the first days of the war, party feeling did not manifest itself in filling the regiments, and many of the officers were taken from the ranks of the Democrats. In 1862 when the first draft was ordered, the Democratic counties were as far along with their quota as those which had been Republican. Again, when the Proclamation of Emancipation was issued, the feeling toward it in the army was no more friendly than in the state, while the attitude toward the administration was equally hostile.

EFFORTS TO STRENGTHEN THE PARTY AFTER THE DEFEAT OF $\mathrm{I} 862$

The defeat left the Union party in a peculiar condition. It was out of touch with the administration on the emancipation policy, and apparently discredited before the country on its war platform. The Democrats asserted boldly that the election meant an endorsement of Democratic principles and a popular verdict against the war. Many mem-

${ }^{1}$ See editorials in Cleveland Leader, Nov. I5th, and in Cincinnati Gazette, Oct. I7th. Yet the Cleveland Leader, on September' 16, 1867, in commenting on this election, said: "In 1862 the Emancipation Proclamation was issued. This frightened the conservatives of southern Ohio, while the radicals of the Reserve, too confident of success in any event, did not come out in strength to the polls. The result was the Democratic majority of five thousand."

${ }^{2}$ See speech of James E. Campbell of Ohio, in House of Representatives, June 16, 1886. Cong. Globe, 49 th cong., 1st sess., p. 5770. 
bers of the new party returned to their former Democratic affiliation, and the Plain Dealer withdrew its support, holding that Lincoln had yielded to the dictation of the Abolitionists, and feeling "that to remain longer silent would be to give ourselves up, body and soul, to the servile insurrectionists, in which name we greet all who would bid the slaves rise and indiscriminately butcher the people of the South." 1 There seemed no possibility of keeping the party together longer on the sole platform of a "vigorous prosecution of the war."

The General Assembly met for its adjourned session on January 5, 1863 , with the Senatorial question still unsolved, and the President's final Proclamation of Emancipation before the country. Governor Tod's annual message was an excellent exposition of the principles of the party, and a manly explanation of the proceedings of the previous year. From the beginning of his term of office, he had devoted his entire time and energy to the support of the administration and the welfare of the soldiers of the state, sending agents and supplies to the battlefields and directing measures for the care of the sick and wounded. Among the governors of the northern states he was foremost in bringing the resources of his state to the aid of the President in his efforts to put down what Tod always termed the "unholy rebellion". However, in his earnestness and impatience, he often assumed a dictatorial attitude which at times made his relations with the legislature unpleasant, and caused many conflicts between the civil and military authorities at Columbus.

In his message, he declared that the objects of the war had not been changed, but that it was still being waged to maintain the government as it had been handed down by the

${ }^{1}$ Editorial, November 3, 1862. 
fathers, with all the rights of the states preserved. "Sincerely believing that the President and those who surround him have acted solely with a view to restoring peace and harmony to our distracted government and to all its citizens whether north or south," he had rendered them all the aid in his power, and had acquiesced in the orders for the military arrests and the suspension of the writ of habeas corpus. He justified the proceeding on the ground that it was necessary, "to enable the several state authorities to raise their quota of troops." Lastly, he urged the passage of an act allowing the soldiers in the field to vote. No mention was made of the recent Proclamation or the acts of Congress on confiscation and emancipation. So far as the governor was concerned, therefore, the Union party should stand in the future on its original platform. ${ }^{1}$

The Unionists, on their assembling at the capital, proceeded at once to deal with the Senatorial question. There was little change in the situation since the adjournment in the preceding April, except that Delano had been eliminated from the contest. Chase had kept in close touch with developments, and hoped that, while not appearing to be a candidate against Wade, he might be named as a compromise candidate when it was found that Wade could not be chosen. $^{2}$ His friends were trying to get the support of the Democratic element of the party through Groesbeck. On January $\mathrm{I} 3^{\text {th }}$, this element held a conference, and drew up a request that the nomination of Wade be not insisted upon, but that some other Unionist of Republican antecedents be taken. This was presented in a Union caucus held two days later, but no promise was made, and when a proposition was made to proceed to ballot, most of the Democratic

'Executive Documents, 1862, pt. i, p. 5.

${ }^{2}$ Parsons to Chase, October 13, 1862. Chase Papers, MS. 
Unionists withdrew. An adjournment was taken until the next evening, when sixty-six of the Union members assembled. The Delano forces went over to Wade and lie was nominated on the first ballot, receiving fifty-six votes. ${ }^{1}$ When the vote was taken in the legislature, he received seventy-five of the Union votes; fifteen gave their support to Ewing and one to Schenck. The Democrats cast their votes for Jewett.

There was much pressure brought to bear, both from the radicals and the Democrats, to get an expression of opinion on the President's Proclamation, but no action was taken on any of the resolutions which were presented on the subject. However, a new pledge was made in the name of the people of the state to render the administration all possible aid both morally and physically in its efforts to put down the rebellion and restore the Union, and a protest was entered against the proposition to divide the loyal stales with the object of attaching any portion of them to the so-called southern Confederacy. ${ }^{2}$

With the assistance of Chase, his friends were able to have a resolution adopted giving a qualified endorsement to the national banking measure then before Congress. ${ }^{3}$ The banking interests of the state were opposed to changing the system, and it was orily with some persuasion that they were brought to give their consent to the resolution. ${ }^{4}$

${ }^{1}$ The Chase men thought this was brought about through some understanding between Wade and the Delano forces made beforehand. Parsons to Chase, December 6, 1862. Chase Papers, MS.

${ }^{2}$ Laws of Ohio, vol. 1x, p. 147.

${ }^{3}$ Letter of J. Q. Smith to Chase, February 6, I863. Chase was asked to draw up a resolution such as he would like to have adopted and send it to them with any suggestions.

"Letter of Peter Zinn to Chase, February 24, I863. "It required some management on our part as the bankers on the committee were opposed to the plan." Chase Papers, MS. 
The matter of giving the franchise to the soldiers was taken up and an act passed providing for the holding of elections at certain times and places, and putting the control of them in the hands of three judges chosen by the electors present when the polls were opened. ${ }^{1}$ The bills proposed in the first session had designated the commissioned officers of each company as judges, and the principal excuse given by the members in the campaign for not having enacted one of the measures, was that this plan would not have ensured free elections and, since the session was just closing when the bills were presented, there had been no time to remedy the defects.

On the whole the session was one of the most strenuous of the period. In addition to the woeful lack of harmony among the Unionists, the Democrats, emboldened by their success in the elections, declared that the new party was discredited before the country and no longer represented the sentiments of the people of the state. As a consequence, their attacks on the administration became more unrestrained and defiant.

Outside of the Assembly, while much was being done to bolster up the party to enable it to resist the attacks of the Democrats, a matter came up which increased the dissension within its ranks. In January the auditor of state, R. W. Taylor, who had been elected as a Republican in 1859, was tendered a position by Chase in the Treasury Department at Washington. At once a petition was sent to the governor by some of the members of the legislature presenting a name for the vacancy, but it was found that the place had already been offered to Kennon, the Democratic Unionist who had headed the ticket in 1862 . At the time all the important offices except those of auditor and lieutenant gov-

${ }^{1}$ Laws of Ohio, vol. 1x, p. 80. 
ernor were in the hands either of Democrats or of Unionists of Democratic antecedents, and the action of the governor brought down a storm of protest from the Republican element on the ground of unfair dealing. As the Ohio State Journal expressed it :

It may be said that the Republicans should disregard old party differences and preferences and accept a Union man of Democratic antecedents, and so they have and so they would again. But might they not be justified in asking the Governor to do the same thing instead of filling all the Republican vacancies in executive offices by appointment from among his old Democratic friends. ${ }^{1}$

Chase attempted to discipline Tod for his action but failed to make any impression. ${ }^{2}$ As a result, Taylor remained in the office until April when, Kennon having been disposed of in the meantime by being appointed a paymaster in the army, he resigned and the chief clerk in the office filled out the term.

${ }^{1}$ Editorial, February 3, 1863.

'Tod's reply was characteristic: "I pledged the Union-loving people of Ohio, when a candidate for their suffrages, that I would ignore all party and discharge the duties of the position with an eye single to the restoration of the Union. This pledge I have thus far redeemed, and with God's blessing, shall continue to do so, during the short time I have yet to remain. This determination prevents my yielding to the demands made by Auditor Taylor and yourself."

His secretary, Judge Hoffman, also wrote regarding the affair, defending the course of the governor, and showing that in his appointments as a whole, he had selected more men of Republican antecedents than otherwise. He blamed the Journal and Leader for attempting to play into the hands of the old Republicans. As to Tod's policy, he said: "His object and desire have been to bury out of sight all old party feeling and prejudice during this rebellion. The things that have vexed him most have been the efforts of some old line Democrats to keep up their party, and the efforts of some unwise Republicans to cut loose from and break up the Union party." Chase Papers, MS. 
This petty bickering in the ranks of a party formed with the avowed purpose of allaying all partisan feeling, addled to the persistent calls of the Peace Democracy for compromise and a cessation of hostilities, the activities of their secret societies and the boldness of their open attacks on the administration, both in the speeches of their leaders in mass meetings and in the editorials of their press; all these tended to bring the Union movement to the lowest ebb it reached during the war, and to create among the troops in the field not only a feeling of rage toward the traitors of the North for their "fire in the rear," but also one of discouragement at the apparent desertion of their friends. In resolutions which the Ohio regiments sent home denouncing the traitors, they also deplored the fact that party spirit and dissension were crushing out all Union sentiment, and admonished the people to lay aside their disputes and act as patriots. ${ }^{1}$ Some of these resolutions were sent directly to the legislature; and brought forth a response from the Union members acknowledging the justice of the rebuke. ${ }^{2}$

In response to a set of resolutions and an address from the officers of the Ohio regiments at Murfreesboro, a mass meeting was held at Cincinnati on February 23d. Groesbeck presided and Governor Morton and Ex-Governor Wright of Indiana, with General Lew Wallace assisted Governors Dennison and Tod in making an appeal to the people of the state to unite in support of the army and the administration. ${ }^{3}$ A similar meeting was held at Columbus on March 3d at which Governor Andrew Johnson made the principal address. Holding that he was still a Democrat, but for the Union, he denounced all Democrats who were

${ }^{1}$ House Journal, 1863, p. 267. Ohio State Journal, March 26th.

' Ohio State Journal, April 16th.

'Cincinnati Commercial, March 4th. 
talking of compromise as traitors to their country. While he was not in favor of carrying on the war for the freeing of the slaves, yet if in crushing the rebellion it was necessary to let the slaves go, he was willing to do it. ${ }^{1}$ Other similar meetings were held in different cities of the state with encouraging results, so that Tod could write to General Sherman, March Ist: "You will be glad to know that the feeling in Ohio relating to the more vigorous prosecution of the war has greatly improved within the past few weeks." 2 The spring elections also gave evidence of a returning enthusiasm among the Unionists.

In order to bind the party more closely together, the movement set on foot at Philadelphia for the organization of Union Leagues was taken up in Ohio. The Cleveland Leader first endorsed the plan. It urged the necessity of some organized effort to counteract the evils of the Copperhead combinations, and called upon every county and township to organize a League at once, with the one platform of a hearty support of the government in suppressing the rebellion, and with the purpose of supplying the public and the soldiers with loyal books and newspapers and of holding Union meetings throughout the state. ${ }^{3}$ The suggestion was taken up in many parts of the state and not only were local Leagues organized, but a state organization was perfected." The effect of this movement was first seen in the results of the spring elections. On May 2oth, a large mass meeting of the League was held at Cleveland. It was addressed by Montgomery Blair, Bingham, and others of national prominence, while letters were read from Senator

'Ohio State Journal, March 4, 1863.

'Executive Documents, 1863, pt. i, p. 164.

${ }^{3} C f$. edition of February 28, 1863.

${ }^{4}$ Constitution in Ohio Statesman, April 26, 1863. 
Sumner and Secretary Chase expressing regret at their inability to attend. The one sentiment of the meeting was the support of the administration in all its efforts to suppress the rebellion. A resolution was adopted calling on the President to carry out the sentence which had just been pronounced on Vallandigham. ${ }^{1}$

But the thing of prime importance was to find a candidate on whom all the elements of the party could unite, and this was a much more serious undertaking than it had been in I86I. Governor Tod, so far as the Wade and Chase forces were concerned, was eliminated early in the year, because of his action in appointing Kennon, and his refusal to advance to the position of the Emancipation Proclamation, ${ }^{2}$ while his part in the military arrests of the preceding year weakened his popularity with the conservatives. Various names were suggested, including those of Bingham, Horton, Delano, and Groesbeck, but no agreement could be reached. The most available candidate seemed to be Stanley Matthews, who was just leaving the army to assume the duties of judge of the superior court at Cincinnati. He

${ }^{1}$ Cf. infra, p. 165 . The Cleveland Herald took a stand against the organization of the Leagues on the ground that it was an attempt to do in an indirect and subtile manner what had been more openly tried before the campaign of the preceding year, namely, to repudiate the Union party and secure the spoils of office. See editorial, May 2I, 1863.

'The question of reviving the Republican party was seriously discussed by the radicals and urged by the Ashtabula Sentinel, but they could not get the coöperation of the conservatives. Bascom of the Xenia Torchlight wrote Chase, February I2th: "I am not clear as to the future; there are difficulties about abandoning the Union party, which may be insurmountable at present. . . Governor Tod has killed himself with the Republicans by the appointment of Kennon . . . It is such a breach of faith . . . as cannot and will not be overlooked. My present impression is that we shall go with the Union party this fall." Chase Papers, $M S$. 
was acceptable to the Chase men, ${ }^{1}$ and could, it was thought, carry the conservative vote, but his name was dropped sometime before the convention was held.

Tod, in an address made in his home county early in April, announced his candidacy for renomination. ${ }^{2}$ With this the radical papers, especially in the Reserve, came out openly in their opposition to him. As the Cleveland Leader expressed it :

We need for a standard-bearer, a true man, and by a true man we mean one who lives in the present and not in the past . . . a man whose principles will plead trumpet-tongued with the earnest men of the State in support of his election. No milkand-water man, .... no mere conservative man, will be able to lead us to victory. ${ }^{3}$

The Union League refused to support him, and through its organization, was the principal cause of his defeat in the convention.

This failure to unite on a suitable candidate, seemed to presage an open fight in the convention. The call was issued on March 3 oth, and the date fixed for the convention was June $I 7$ th. The delegates were to be apportioned among the counties on the basis of the votes cast for the Union ticket in I86I, instead of the aggregate vote. An unusual effort was put forth to make the event an occasion for a great revival of Unionism, and with this in mind a supplementary call was issued, June 8th, to all "unconditional Union men" to meet on the date set in a grand mass

${ }^{1} \mathrm{~J}$. H. Geiger in a letter to Chase, April roth, proposed his name. Chase wrote Matthews, April r6th, asking him what his sentiments were on the matter. There is no answer from Matthews in the Chase papers.

${ }^{2}$ Crisis, May 13, 1863.

3 Editorial, June 6th. 
convention, " to aid and encourage each other by their presence and counsel." This effort was increased after June I Ith, when the Democrats, amid great enthusiasm, nominated Vallandigham and Pugh to head their ticket.

An unexpected development took place a few days before the assembling of the convention. John Brough, president of the Bellefontaine and Indianapolis railroad, with headquarters in Indianapolis but maintaining a residence in Cleveland, was brought forward as a candidate. ${ }^{1} \mathrm{He}$ was a native of Marietta, and had been prominent in Democratic circles, and editor of the Cincinnati Enquirer in his earlier years, but had not taken an active part in politics since I848. On June Ioth, he delivered an address at his old home on the questions of the day, in which he expressed a strong determination to support the administration in the conduct of the war. He had been a life-long Democrat, and had opposed Lincoln's election and probably would not vote for him at any time; but Lincoln, he said, was the President and the head of the government, and "like a soldier in the ranks I hold it to be my duty to obey him, my commanding officer, in all things without questioning his policy in this great contest." As to slavery, he had no quarrel with it as a domestic institution, but it had assumed a political character and because of this, it must perish with the war. He had not thought Lincoln wise in issuing his Proclamation,

\footnotetext{
${ }^{1}$ The author was not able to ascertain with certainty who were responsible for the launching of the Brough boom. Gen. Wright in Ohio Arch. and Hist. Society Publications, vol. viii, p. 122, says it was conceived by "one member of the Legislature from Washington county, together with a gentleman of this city (Columbus), who was a politician and had favored the nomination and election of $\mathrm{Mr}$. Tod, . . . but had become offended at the Government failing to appoint some friend of his to some position." The Chase men, as their correspondence shows, were not on the inside of the affair, and the nomination came as a surprise to them. The Democratic papers of the day held that the railroads were back of the boom." See Crisis, July 8th.
} 
but felt that it might work out for the best after all. $\mathrm{He}$ justified the taking of the slaves because, if property, the rules of war allowed it, and because each slave working on a plantation was worth two soldiers fighting in the field. On the matter of military arrests, he held that there was no doubt of the government's power to protect itself; and as for peace, since the southern leaders had howled down all peace propositions, he did not see how an honorable peace could come except by the arbitrament of the sword. ${ }^{1}$

The two Cincinnati papers, the Commercial and the Gazette, printed the speech in full, and began a vigorous campaign for Brough. The Cleveland Leader took it up, and called for a mass meeting in that city to endorse him for the nomination. The radicals, too few to bring about the nomination of one of their own number, accepted him as their candidate because of his sentiments on the Proclamation, and the Union League threw its support to him. Tod carried his fight into the convention, however, many of the delegations which had been selected before the Brough boom was launched, being pledged to him. On the first ballot he received one hundred and eighty-four votes; but Brough received two hundred and twenty-six and thus was nominated. ${ }^{2}$

The resolutions, as reported to the convention by Wade, denounced the Calhoun doctrine as reiterated by the Democrats in their platform, and declared that the war must go on with the utmost vigor until the authority of the national government should be reëstablished. All party lines were

\section{${ }^{1}$ Cincinnati Commercial, June 12, 1863.}

${ }^{2}$ Tod took his defeat rather hard. Writing to Gov. Andrews of Mass. he said: "You will have heard of my defeat in the Union Convention recently held in this city. It is proper that I inform you that personal considerations alone caused my defeat." Executive Documents, 1863, pt. i. p. 274 . 
to be obliterated except "the great line between those who sustain the Government of the country, and those who oppose it; between those who rejoice in the triumph of our arms, and those who rejoice in the triumph of the enemy." Sympathy was expressed for the army in its hardships, and assistance promised to it, and to the families of those who fell. "Confiding in the honesty, patriotism and good sense of the President," support was pledged to him in his earnest efforts to put down the rebellion. Governor Tod was consoled with a resolution recognizing him as "an honest and able public servant," and approving his official conduct.

Outside of their satisfaction with the candidate for governor, the radicals derived little from the convention. A proposition to include in the platform a plank on emancipation received only five out of nineteen votes in the committee, ${ }^{1}$ while their candidate for judge of the supreme court, Bingham, was defeated by Hocking Hunter, a conservative.

The energetic labors of the Union leaders in the campaign, assisted in every way by the administration and fortified by the victories at Gettysburg and Vicksburg, resulted in the defeat of the Vallandigham ticket in the October election by over a hundred thousand majority, after the most exciting campaign in the history of the state. With this result, support of the administration in its war policy became solidified in the state. The Union party passed its period of precarious existence, and there was no further talk of its disbandment. The details of the campaign can best be considered from the standpoint of the Peace Democracy, and hence will be discussed in the next chapter.

THE UNION PARTY IN THE CAMPAIGN OF I 864

The legislature, chosen in the election, stood overwhelm-

${ }^{1}$ Ashley to Chase, June 23, 1863. Chase Papers, MS. 
ingly Unionist. In the Senate there were twenty-nine Unionists and five Democrats, while in the House there were seventy-four Unionists and twenty-three Democrats. The work of the first session, which convened in January, 1864, was largely of a routine nature, and it was carried on with little show of opposition. The resolution by which the Corwin Amendment was ratified in $\mathrm{I} 86 \mathrm{I}{ }^{1}$ was rescinded, on the ground that the necessity for such an amendment had been removed by the events of the war, and that the resolution under the circumstances "is an impediment to the free action of Congress in the present exigencies of the country as well as a misrepresentation of the public sentiment of the people of Ohio." 2 On the retirement of Governor Tod, the thanks of the Assembly were extended to him for his devotion in ministering to the sick and wounded soldiers and his assistance in providing for their families, for his speedy suppression of disloyalty and resistance to the laws, for his deep-toned loyalty, and for the full and faithful discharge of the trust committed to him by the people. $^{3}$

With the adoption of resolutions in several of the northern states calling for the renomination of Lincoln, the question of a Presidential candidate was injected into Ohio politics early in the year. Chase, as has been noted, had been working among his Ohio friends for more than a year with a view to uniting the state in his support. With the convening of the Assembly, he began to make overtures to the Delano forces which were strong for Lincoln. Delano himself had been elected as a representative, while Hubbell, who had been leader of this faction in the Senatorial contest of the preceding Assembly, was Speaker of the House.

${ }^{1}$ Cf. supra, p. 69.

'Laws of Ohio, vol. 1xi, p. $182 . \quad$ 'Ibid., p. 167. 
Early in January, a committee made up of United States Senators, Representatives, and citizens was formed to secure the nomination of Chase, and to them he consented with feigned reluctance to allow his name to be used. ${ }^{1}$ During the next month, this committee issued a confidential circular signed by Senator Pomeroy of Kansas asserting that the election of Lincoln would be impossible, owing to the influences which would oppose him, and that Chase possessed the qualities needed in a President during the next four years. To secure his nomination, the coöperation was invited of "all those who are in favor of the speedy restoration of the Union on the basis of universal freedom" and who desired an administration of the government which should develop the capacity of free institutions, and make American nationality a model before the world. ${ }^{2}$

Before this circular was issued, a promise was secured by the lieutenants of Chase from the opposing faction, that no resolution endorsing Lincoln should be offered in the legislature, ${ }^{3}$ and when a caucus of the Union members was held on February 4th to discuss a date for the adjourning of the session, the consideration of such a resolution which had been prepared was successfully blocked. ${ }^{4}$

'Schuckers, Life of Chase, p. 497.

${ }^{2}$ Schuckers, Life of Chase, p. 499.

${ }^{3}$ R. C. Parsons of Cleveland, whom Chase had appointed U. S. Tax Collector, was his principal lieutenant in Ohio. He and other Chase appointees were in Columbus working to prevent the adoption of such a resolution. An agreement was made with Delano, by which in consideration of his not urging the resolution, he should have the support of the Chase men in securing the appointment to the supreme bench in place of Hunter who had just resigned. Parsons to Chase, Feb. 4th. Chase Papers, $M S$.

'Parsons to Chase, Feb. 6th, said he and his friends were acting with energy, and had the resolution been introduced it would have met with a decided evidence of hostility. Chase Papers, MS. 
But the tide of popular sentiment was setting in strongly for Lincoln, and when the Pomeroy Circular was made public on February 2oth through the Washington Constitutional Union, it produced a "perfect convulsion in the party." 1 Fortified by this, the Lincoln supporters, in a party caucus held five days later, were able to carry a resolution "that in the opinion of this convention, the people of Ohio and her soldiers in the army demand the renomination of Abraham Lincoln to the presidency of the United States." 2 Chase's hopes for the nomination were completely blasted by this action, and on March $5^{\text {th }}$ he wrote that, owing to the preference shown for another by the people of Ohio, "it becomes my duty-and I count it more a privilege than a duty - to ask that no further consideration be given to my name." 3

This resolution, while engineered by a cabal of politicians acting through vindictive motives, nevertheless voiced the opinion of a great majority of the people of the state and of the entire North. When the Union state convention met, May $25^{\text {th }}$, to nominate a state ticket and select delegates to the national convention, the Lincoln sentiment was uppermost, and the resolutions called for his renomination, at the same time pledging the cordial support of the Union men of the state to the measures which marked his administration and especially approving the pending amendment to the Constitution. ${ }^{4}$ The platform also congratulated the country on the success of the armies, and proclaimed with pride the fact that, " in the Cabinet, in the field, and in the coun-

'Parsons to Chase, March $2 \mathrm{~d}$.

'About 63 of the 103 Union members of the Assembly were present when the resolution was adopted, most of the Chase men having withdrawn.

${ }^{3}$ Chase to James C. Hall of Toledo. Schuckers, Life of Chase, p. 502.

-This was later adopted as the Thirteenth Amendment. 
cils of the Nation, the ability, fidelity and patriotism of Ohio have been proudly manifest."

A resolution to endorse the work of Chase in connection with the finances of the country was presented in the committee, but was opposed by Bingham and some of the other members on the ground that the greenbacks were depreciating and might fail entirely. Some opposition was shown even to including him in the resolution on the war, which, as originally drafted, referred only to those in the field. It was finally amended, however, to include the Cabinet. ${ }^{1}$

As delegates to the Baltimore convention, Dennison, Tod, Delano and Dorsey were selected. The first named, chosen to preside over its sessions, sounded the keynote of this, the first national gathering of the Union party, as follows:

In no sense do we meet as members or representatives of either of the old political parties. . . . The extraordinary condition of the country since the outbreak of the rebellion has, from necessity, taken from the issues of these parties their practical significance and compelled the formation of substantially new political organizations, hence the origin of the Union party . . . of which this Convention is for the purposes of its assembling the accredited representatives, and the only test of membership in which is an unreserved, unconditional loyalty to the government and the Union. ${ }^{2}$

The campaign of 1864 lacked the excitement and bitter-

'W. D. Bickham to Chase, May 29, I864. Chase Papers, MS. Chase received further humiliation later in the year. He was urged to accept the nomination for Representative in the Cincinnati district by several of his friends, and on the representation to him that he would be nominated by acclamation, he consented to allow his name to be presented to the convention. In reality those who were at the bottom of the plan, devised it solely to defeat Benj. Eggleston, the opposing candidate. Eggleston's friends packed the convention, however, and Chase was defeated.

${ }^{3} \mathrm{McPherson}$, History of the Rebellion, p. 405. 
ness of that of the preceding year. The Democracy was divided on its national platform, and the probable success of the war gave it a certain hopelessness. The Unionists carried the state ticket in the October election by a majority of 54,000, and won seventeen of the nineteen seats in Congress. A month later Lincoln obtained a majority of 60,000 .

With the close of the war, the work of the Union party seemed to be finished. The Union was restored, and by the passage of the Thirteenth Amendment slavery was abolished; so the party was without a platform. The question of whether or not the organization should be abandoned received much consideration during the months following the close of hostilities. The opinion of many was voiced by the Cincinnati Commercial which declared that, having fulfilled its mission, it should pass from the scene as the old Republican party had done, to give way to new parties. ${ }^{1}$ On the other hand, it was maintained that there was still work for the party to do in securing the results of the war, and that to disband it at such a time would be to give up what had been accomplished during the four years of strife. The consequence was that the organization was maintained, and the problems of the Reconstruction period succeeded those of the war. To the state itself, the question of negro suffrage was the most important of these, and it occupied a prominent place during the campaigns of 1865,1866 and I867, the details of which will be treated in a later chapter.

In 1867 the party began to use the name "Union Republican" to distinguish it from the Johnson, or "National Union" party of the previous year, and in the Presidential campaign of 1868 this was adopted by the national organization. The Republican party which had been formed in

${ }^{1}$ Cf. editorials, Dec. 28, 1865, and Jan. 6, 1866. 
I854 was never revived in Ohio after its demise in 1861. The issues upon which it had been formed were settled by the war. The new party formed in 186I outlived the war, and continued its existence with new issues. The present Republican party is not, therefore, a successor of the organization of 1854 , but rather, of the Union party of the war period. 


\section{CHAPTER III}

\section{Vallandigham and the Peace Democracy}

THE PEACE DEMOCRACY DURING THE EARLY PART OF THE WAR

Writ the formation of the Union party, those who remained with the old Democratic organization constituted the opposition party of the war period, or as they were pleased to call themselves, the "Peace Democracy." Failing to respond to the sentiment which inspired the majority of the people North, they continued to use argument when emotion was dominant. They took issue with the Unionists as to the nature of the struggle, and refused to believe that the South was engaged in a war of conquest, but held that it had been precipitated by the Abolition fanatics of the North. Contending that the South could never be conquered by arms, they called for a cessation of hostilities and the summoning of a national convention to adjust the differences between the sections. They denied the right of secession, but also denied the right of any section to interfere with the domestic institutions of any other, and took issue with the doctrine of Lincoln that the Union could not endure half slave and half free. They were careful to distinguish between the government and the administration, and assumed the task of defending the former against the arbitrary and unconstitutional assaults of the latter.

The principal exponent of the party in the East was Fernando Wood of New York, while the name most closely 128 
associated with it in the West was that of Clement L. Vallandigham of Ohio. Born of Huguenot ancestry in New Lisbon, Columbiana county, Vallandigham had from early life been a close student of politics. After representing his county for two terms in the state legislature, he removed to Dayton to take up the practice of law in connection with the duties of editor of the Western Empire, later, under the name of the Dayton Empire to be one of the most radical peace organs of the state. With a mind developed by a severe system of training, possessed of great personal magnetism and extraordinary powers of oratory, and stimulated by an unbounded ambition, he was particularly prominent among his contemporaries in the state.

In 1852 he began a long struggle with Lewis D. Campbell, then a Whig, for the privilege of representing the third district in Congress. Twice defeated, he successfully contested the election of his opponent in 1856 , and was seated in the early part of 1858 . From that time until his defeat in the elections four years later he was constantly before the public notice because of his pronounced views on the questions of the day. His first important speech in Congress, delivered on December I4, I859, contained a statement of his creed. He was not a northern man, he said, nor a southern man, though " in this unholy and unconstitutional crusade against the South" his sympathies were with her. He had come into the House an intense nationalist, but in the division by sections he had become a western sectionalist. The West, long ignored by the North? ? would soon hold the balance of political powver and control the destinies of the country. Within the Union, by the network of railroads, she must remain tributary to the North, but once the Union was dissolved nature would reassert herself, and the Mississippi and its tributaries would become the arteries of trade. His plea, therefore, was for 
the Union as better for all the sections. He was for the "Union as it is and the Constitution as it is." 1

He would resort to no forcible measures thus to preserve the Union, but would overcome any necessity of destroying it by removing the temptation of the majority to impose on the minority. He found fault with the various peace propositions before Congress because none of them dealt with this means of conciliation, but all aimed at checking the power of the majority by mere constitutional prohibitions. ${ }^{2}$ On November 2, I860, he delivered a speech at Cooper Institute, New York city, in which he made the statement so often quoted in the years following:

If any one or more of the States of this Union should at any time secede ... for reasons of the sufficiency and justice of which, before God and the great tribunal of history, they alone may judge ... much as I would deplore it, I never would, as a representative in the Congress of the United States, vote one dollar of money, whereby one drop of American blood should be shed in a civil war. ${ }^{3}$

On February 7, 186I, he offered his notable series of resolutions in the House for amending the Constitution, in order to get rid of the division of the country into slaveholding and non-slaveholding sections, by creating other sections without regard to slavery, no one of which was to be strong enough to oppress or control the others. The New England states with New York, New Jersey and Pennsylvania were to constitute one section, to be known as the North; the states of the Northwest territory with Minnesota, Iowa and Kansas were to be grouped together as the

'Cong. Globe, 36th cong., Ist sess., App., p. 42.

'Speech on "How shall the Union of these States be Restored and Preserved?" Cong. Globe. 36th cong., 2nd sess., p. 235.

${ }^{3}$ Vallandigham Record, p. 91. 
West; Oregon and California were to form a third section called the Pacific; while the border and southern states were to be known as the South. To preserve the balance of power among these sections, he devised a system of concurrent majorities similar to that advocated by Calhoun. ${ }^{1}$ On every measure of Congress requiring the concurrence of both houses, a vote should be taken by sections on the demand of one-third of the senators of any scction, and a majority of the senators from each section voting should be necessary for its passage. A majority of all the electors in each of the sections was to be necessary for the choice of a President and Vice-President, who were to hold office for a term of six years, and were not to be eligible to more than one term except by the votes of two-thirds of all the electors of each section. No state was to secede without the consent of the legislatures of all the states composing the section to which it belonged. Finally, the citizens of all the sections were to have equal rights in the territories of the United States. ${ }^{2}$

This idea of regarding the West as a section having its own local consciousness, with no part in the quarrel between the North and South and no interest in it except to preserve the Union of the states, was not original with Vallandigham, nor was its expression confined to the Democracy. A few days before Vallandigham made his first speech, Corwin said in the House: "We of the West do not mean to be held responsible to the North or to the South . . . we mean to preach good and wholesome doctrines to both, and if we possibly can, preserve and cherish fraternal relations with both." 8 Again, the sentiments expressed dur-

" "Disquisition on Government," Works, vol. i.

'McPherson, History of the Rebellion, p. 56.

'Cong. Globe, 36th cong., Ist sess., p. 73. 
ing the visit of the Kentucky and Tennessee legislatures to Ohio manifested the same feeling. ${ }^{1}$ But when the decision of the West was made in I86I to unite with the North in the war, the continued advocacy of this idea, and the attempt to sever the two sections again could be considered by the Unionists only as a determination to assist the South.

In his advocacy of peace, Vallandigham was supported by his colleagues in Congress, Pugh and Pendleton. At a meeting of the Ohio delegation on December I7, I860, these members made a great fight for conciliation and compromise, much to the disgust of their Republican associates. ${ }^{2}$ In the Senate during the debate on the Crittenden compromise, Pugh urged the suspension of any law which was causing trouble between the sections and the acceptance of any measure looking toward peace, ${ }^{3}$ while Pendleton in presenting a petition from ten thousand of his constituents to the House, begged that all reasonable demands of the South should be granted. The states of the northwest were, he was sure, devoted to the maintenance of the Union, on account of their inland position as well as their affection. If maintaining it were a question of blood or riches, the people of those states would furnish both; but, he contended, " money, armies, blood will not maintain the Union. Justice, reason, peace may." " The endorsement of the peace idea in the resolutions adopted by the Ohio Democracy in their convention, January $23,1861,{ }^{5}$ and the responses from the neighboring states on the west, enabled Vallandigham to write:

But one thing we have accomplished, there will be no war

${ }^{1}$ Cf. supra, p.31.

'Letter of Ashley to Chase, Dec. 20, 1860. Chase Papers, MS.

'Cong. Globe, 36th cong., 2d sess., App., p. 29.

"Ibid., App., p. 70.

${ }^{3}$ Cf. supra, p. 54 . 
now. I think peace for the present has been secured. . . . Alone among public men of the Free States I took my position early in November amidst reproach and persecution, and even when we met here on the $3 \mathrm{~d}$ of December no man stood by me except Pendleton and Pugh. We three began the battle for peace, and now Ohio, Indiana and Illinois are with us through State Conventions of the Democratic party. . . . Before God I believe that if Pugh and myself had not placed ourselves in the breach, this country would have been in the midst of a civil war to-day. . . . The great fight which we made in the Ohio caucus on the night of the I7th of December saved us that calamity-at least up to this point. ${ }^{1}$

When Congress adjourned on March 4, I86I, Vallandigham returned to Ohio. He visited the legislature during the days just preceding the outbreak of hostilities to induce the Democratic members to vote against all war measures. On the publication of the proclamation of the President, May 3d, calling out volunteers and increasing the regular army and navy, he issued a private circular to some of the leaders of the Democracy in the state proposing a conference to deliberate on measures to "rescue the Republic from an impending military despotism," " but in the enthusiasm of the moment, no interest was manifested, and the conference was not held.

In addition to Vallandigham, Pugh and Pendleton, there were other able men in the state who refused to follow the North into war. Of these the most important were Samuel Medary, Ex-Senator Allen and his nephew, Allen $\dot{G}_{\text {. }}$ Thurman, the first two having been prominent in political affairs since the time of Jackson. Medary was for many years editor of the Ohio Statesman. In 1857 he was ap-

1 J. L. Vallandigham, Life of Vallandigham, p. 152.

'Ibid., p. 16r. 
pointed governor for Minnesota Territory, and two years later was sent to Kansas in the same capacity. Returning to Columbus in December, 1860, he established the Crisis, and made it one of the most earnest advocates of peace in the North. Allen had represented the state in the United States Senate from 1842 to 1848 , after which he retired from active politics and became a sort of patriarchal adviser to his party. Thurman received his political training from his uncle. Prior to the war he had served in Congress and on the supreme bench of the state. As a whole, the men who guided the Democracy through the war period were possessed of unusual ability, and in command of a powerful minority, they formed a worthy and dangerous opposition to the administration. As they had been with very few exceptions Douglas men in 1860 , the Peace Democracy can in no sense be said to have grown out of the Breckinridge faction.

After hostilities had begun, the party turned its attention to a consideration of the objects of the war and the questions which arose in connection with its prosecution. In the special session of Congress which convened in July, I861, the Democratic members from Ohio offered various resolutions, all having in view the preservation of the rights of the states. ${ }^{1}$ On July $22 \mathrm{~d}$, when Crittenden introduced his resolution on the cause and objects of the war, ${ }^{2}$ and a vote was taken on a division of the question, the Ohio members with the exception of Vallandigham voted affirmatively on the first part and all gave their assent to the second part.

As has already been noted, those who controlled the machinery of the party in Ohio rejected the invitation to abandon it to enter the new Union organization and refused

${ }^{1}$ McPherson, History of the Rebellion, p. 286. $\quad{ }^{2}$ Cf. supra, p. 82. 
to take the movement seriously. They held that the Democracy was the true Union party, and that it was folly to think of such rank disunionists as Wade and Giddings and their followers becoming real Unionists. It was also argued that the Republicans were not sincere, but only desirous of unloading principles they could no longer maintain and of escaping responsibility for the corruption and partisanship of Governor Dennison's administration, and thus saving the party from defeat in the fall elections. The Democratic leaders consequently never admitted that a new party had been formed, but continued to speak of their opponents as Republicans and denounced as "renegades" all who, like Tod and Dorsey, left the Democratic ranks. In thus keeping prominent the old hated party name of their adversaries, they were able to deter many of their number from joining the Union movement who otherwise might have done so.

It is difficult to determine how large a following Vallandigham and his associates had in the party during the year I86r. It is certain that there was a large conservative element represented by Ranney and Jewett who, while unwilling to give up their party affiliation with the Democracy, were not prepared to advance to the position occupied by the extremists. In certain sections of the state, notably in the third and fifth congressional districts ${ }^{1}$ and in Ashland and Franklin counties, the resolutions adopted prior to the state convention were of a radical type, and the platform as adopted at the state convention contained a complete enunciation of the peace doctrines. Yet the candidate, Jewett, was a moderate, and in his modification of the platform, tempered it materially. But even so, the

${ }^{1} 3 \mathrm{~d}$ District-Preble, Butler, Montgomery and Warren counties. 5th District-Van Wert, Mercer, Allen, Auglaize, Hancock, Hardin and Wyandot counties. 
decisive victory of the Unionists in the October elections, not only in Ohio, but throughout the North, gave the Democratic party little to hope for in the future, and even threatened its very existence. ${ }^{1}$

In the face of this situation, however, attempts were made to revive the party, and bring together its various elements. Two caucuses of the Democratic members of Congress were held at Washington for this purpose in December, but both broke up in confusion. There seemed to be no platform on which an opposition party could continue. In March of the next year, I862, taking advantage of the growing opposition to the policy of confiscation and emancipation, Vallandigham drew up a call for a conference of the Democratic members of both houses and obtained thirty-five signers. The meeting was held on the $25^{\text {th }}$ of that month, and the appointment of a committee to prepare an address to the people of the country was ordered. In the meantime an effort was being made by some of the eastern Democrats to combine with some of the old Whigs and Americans and form a new conservative organization under a new name; through the manipulations of those concerned in this enterprise the appointment of the committee was delayed, with the object of defeating Vallandigham's move. Vallandigham prepared the address, notwithstanding, and it was published on May 8 th, a few days before the date set by the conservatives for formally launching their project. ${ }^{2}$ To it were subscribed the names of six of the Democratic members from Ohio, ${ }^{3}$ three from Illinois, two from Indiana, two from Pennsylvania, one from Oregon and one from New Jersey. Re-

${ }^{1}$ Rhodes, History of the U. S., vol. iii, p. 487.

$2 \mathrm{~J}$. L. Vallandigham, Life of Vallandigham, p. 204.

s Vallandigham, Pendleton, Allen, White, Noble and Morris. Cox and Nugent, the other two, did not sign. 
viewing the great achievements of the country under Democratic rule, the address concluded that " neither the ancient principles, the policy, nor the past history of the Democratic party require nor would justify its disbandment," and that the immediate issue before the country was, "to maintain the Constitution as it is and to restore the Union as it was." To do the first was to "respect the rights of the States and the liberties of the citizen," while to accomplish the second, it was "essential to give assurance to every State and to the people of every section that their rights, liberties, and property will be secure within the Union under the Constitution," and to crush out sectionalism North and South, through political organization and the ballot box. The charge that the party was opposed to supporting the government and in favor of disbanding the armies was denied as libelous and false. Yet while recognizing it as their duty " to support the Government in all constitutional, necessary and proper efforts to maintain its safety, integrity and constitutional authority," they were "inflexibly opposed to waging war against any of the States or people of this Union in any spirit of oppression or for any purpose of conquest or subjection or of overthrowing or interfering with the rights or established institutions of any State." 1

Throughout the winter of $186 \mathrm{I}-2$ in Congress, Vallandigham, in defending his peace doctrines, drew upon himself the attacks of the Unionist members. Ohio politics came into the discussions so prominently as to draw from a member from Illinois the remark, that for four sessions the political situation in Ohio and the principles of the members from that state had been discussed, and he thought sufficient time had been devoted to that subject. Petitions were

${ }^{1}$ Crisis, May 14, 1862. 
presented from several Ohio districts calling for the expulsion of Vallandigham as a "traitor and a disgrace to the State." The conference of March 25th was made the subject of a bitter attack on him in the Senate by Wade. Asking who were the men concerned in the reconstruction of the Democratic party, he accused them of a " deliberate purpose to assail ... and to overawe, intimidate and trample under foot if they can, the men who boldly stand forth in defense of their country, now imperiled by this gigantic rebellion." $\mathrm{He}$ characterized their leader as "a man who never had any sympathy with this Republic, but whose every breath is devoted to its destruction just as far as his heart dare permit him to go." 1 Three days later in the House Vallandigham branded his colleague as "a liar, a scoundrel and a coward." 2 This led to the introduction of a resolution of censure by Hutchins, the successor of Giddings in the House, but it was declared out of order by the speaker on a technicality. The stormy scenes and bitter attacks which characterized the session contributed much toward solidifying the Democracy and widening the gulf between the two parties, and the quarrels of the Ohio members were transferred when Congress adjourned to the state campaign.

The address of Vallandigham and his associates had a marked effect in stimulating the Peace Democracy of Ohio as the time for the campaign came on, and under the slogan, "The Union as it was and the Constitution as it is," the local conventions were held and resolutions adopted embodying, in the Democratic strongholds, the sentiments thus promulgated by their leaders. Those of Butler county went perhaps the farthest. They endorsed the Virginia and Kentucky resolutions; opposed the emancipation of the

'Cong. Globe, 37th cong., 2d sess., p. 1735.

'Ibid., p. 1829 . 
slaves by the Federal government, " as necessarily calculated to overrun the free States with a brutalized and worthless race, and to beget a ruinous competition with, and to degrade free white labor;" and complimented Vallandigham "for the honest, bold and faithful manner in which he has fulfilled his trust." The dissension in the Union party, and the growing opposition to the administration throughout the West, gave the Democrats much cause for hope.

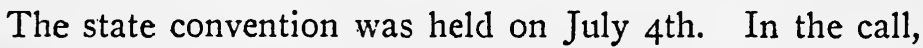
"the Democratic voters, and all others in favor of the Union as it has been and the Constitution as it is "were invited to participate, and those who assembled were ready to take advantage of the unpopularity of the administration. Medary presided, and the committee on resolutions included Vallandigham, Thurman, Ranney and others prominent in the party who represented all shades of opinion. The platform covered all the questions at issue at the time. Holding that the Democracy embraced " the devoted friends of the Constitution and the Union," and had no sympathy with the enemies of either, it denounced the Abolitionists for forcing party issues at a time when all loyal people of the Union should present an unbroken front; and for giving aid and comfort to the rebel cause by their denunciation of the President whenever he manifested a conservative spirit; by their " atrocious defamation of our generals;" and by their "persistent representation of all conservative men in the loyal States as sympathizers with the rebels." The acts of confiscation and emancipation were opposed not only because they were unconstitutional, but because they would have a tendency to prolong the war by driving the rebels to desperation, and would if carried out engender a feeling of bitterness between the sections which would not be allayed for generations, would destroy for years 
the industrial interests of a large section of the country, and would throw upon the border free states and especially upon Ohio a large number of negroes to compete with and undermine the white laborers of the state. The rights secured by the Constitution were quoted, and the President was denounced for his violation of them. Finally, the illegal and unconstitutional seizure of citizens for alleged political offences was viewed with indignation and alarm, and all who wished to uphold the Constitution were called upon to unite " in denouncing such flagrant violations of State and Federal Constitutions and tyrannical infractions of the rights and liberties of American citizens."

The recent use of the military in Indianapolis on the occasion of the assembling of the Democratic state convention there furnished Vallandigham a theme for an address to the delegates. As to the accusation made against the Democratic party that it sympathized with treason and disunion, he said :

I tell you, men of Ohio, that in three months, in six weeks it may be, these very men and their masters in Washington whose bidding they do, will be the advocates of the eternal dissolution of this Union, and denounce all who oppose it as enemies to the peace of the country. Foreign intervention and the repeated and most serious disasters which have lately befallen our arms will speedily force the issue of separation and Southern independence... disunion or union by negotiation and compromise.

Between these two he was for the Union, the whole of it if possible, but if not, "then for so much of it as can be rescued and preserved, and in any event and under all circumstances for the Union which God ordained, of the Mississippi valley and all which may cling to it under the old name, the old Constitution and the old flag." Medary was. 
addressed as a "blessed martyr" because, after forty years of devotion to the Constitution and the Union, he was compelled in his declining years to see his paper prohibited from circulation through the mails as disloyal to the government. The arrest of Kees, ${ }^{1}$ a few days before, led Vallandigham to ask why those who were depriving citizens of their rights did not take up their muskets and march to the South " to meet the embattled hosts of the Confederacy, instead of threatening, craven like, to fight unarmed Democrats at home-possibly unarmed and possibly not."

Thurman also addressed the convention on the political situation. Never, he contended, since written history had begun had a party made such a sacrifice of its feelings, prejudices and opinion, in order to support an administration it did not elect, as had the Democracy, and yet, though they had uttered no word in favor of secession or made an argument in support of the dissolution of the Union, they were denounced by the Abolitionists as rebel sympathizers because they would not consent to make the war one for emancipation. In connection with the arrest of Kees, he denounced the sending of a little country editor under arrest to Fort Warren on a pretext of enmity to the Union, while Wendell Philips, who had been boasting of his disunion sentiments for nineteen years and who was proclaiming the war infamous unless waged for the purpose of emancipation, was traveling through the country at will giving utterance to his disloyalty. ${ }^{2}$

The convention was dominated by the Peace element, and the nomination of Judge Ranney to head the ticket was made in order that the faction which he represented might be held in line. The whole affair was a triumph for Vallandigham, who made three separate speeches during the

${ }^{2}$ Cf. supra, p. 107.

${ }^{2}$ The convention speeches are given in full in the Crisis, July $23 \mathrm{~d}$. 
few days the delegates were assembled. The party found a new issue in assuming the rôle of guardians of the Constitution against an administration which was disregarding its precepts and violating its fundamental provisions. The platform contained no mention of a national convention, but pledged "earnest support to all proper measures to put down the rebellion," and promised to "make all the allowances that the necessities of the case require of good citizens." The issue was raised solely on the question of violations of the Constitution.

The campaign from the Union party standpoint has already been discussed. ${ }^{1}$ Arbitrary arrests, destruction of Democratic newspaper offices, and the abolitionizing of the war formed the specific counts against the administration, while the drafting of citizens, though admitted to be a constitutional right of the executive, requiring obedience, was deplored because of the object for which the drafted men were to be used, and the people were urged to vote so that in the future there should be no occasion for such measures.

As the campaign progressed, the leaders of the radical element of the party assumed an increasing boldness in their denunciation and invective. ${ }^{2}$ His acceptances of Gov-

${ }^{1}$ Cf. supra, p. 107.

${ }^{2}$ The more important papers of the state which represented the Vallandigham element were: the Ashland Union, the Ohio Eagle (Lancaster), the Dayton Empire, the Stark County Democrat, and the Crisis. The Ohio Statesman and Cincinnati Enquirer were more conservative.

The height of invective was reached in the following editorial: "Hired Hessians going to the sunny Southern soil to butcher by wholesale, not foreigners, but good men, as exemplary Christians as any of our men who believe they are fighting for God-given rights. This is a damned abolition war, and we believe Abe Lincoln is as much of a traitor as Jeff Davis." Ashland Union, quoted in the Cincinnati Commercial July Irth.

The Dayton Empire, July 24th, said: "The Republican party, its 
ernor Tod's invitation to assist in the raising of troops caused Ranney to be all but repudiated. On July 23d, in company with Samuel Galloway of Columbus, a Unionist of strong anti-slavery proclivities, Ranney addressed the people of Lancaster urging such a prosecution of the war as would put down every traitor in arms and holding that he had never seen one cause cited that would in any way justify the rebellion. ${ }^{1}$ In the issue of the Ohio Eagle, the next day, his name was removed from the Democratic ticket which that paper had placed at the head of its editorial column. This act precipitated a somewhat heated discussion throughout the Democratic press of the state. It was applauded by the extremist papers, and Olds, then making his campaign for the congressional nomination, gave it strong approval and denounced Ranney as an Abolitionist. On August 28th the name was replaced, the editor then giving as his reason for removing it, his dislike of the company in which Ranney was traveling. ${ }^{2}$ Ex-Senator Allen, in a speech delivered at Chillicothe, October 4th, pictured the evils of negro emancipation as follows:

Suppose that the contemplated emancipation should be inaugurated successfully. Seven or eight hundred thousand negroes with their hands reeking with the blood of murdered women and children would present themselves at our southern border demanding to cross into our State as Ohio's share of

leaders and its representatives are responsible for the war. They defeated the Crittenden compromise. The blood is upon their hands. Like the mark upon Cain, it remains to show honest men now and the unborn millions of the future the destroyers and murderers of their country."

${ }^{2}$ Cincinnati Commercial, July 25, 1862.

${ }^{2}$ The replacing of the name was probably due to the fact that Governor Tod had, a few days before, requested the editor to come to Columbus for an interview in regard to the matter. 
the freed slaves. Then would come the conflict between the white laborers and the negroes. ${ }^{1}$

The Unionists had little with which to meet these attacks, except to make an appeal to the patriotism of the people of the state, and to brand their opponents as traitors.

\section{EFFECT OF THE ELECTION OF I862 ON THE PEACE DEMOCRACY}

The result of the fall elections, while largely due to the opposition of the conservative element of the Union party throughout the North to the emancipation of the slaves and to the arbitrary arrests, was interpreted by the Peace Democracy to be a condemnation of the whole war policy. Led by this to the mistaken belief that the voice of the people had been given for peace, they assumed a boldness in their attacks on the administration which caused Lincoln to dread the "fire in the rear" more than the enemy in front. Medary in the Crisis figured from the returns, the majority by which a Democratic President would have been elected had there been a national election thit year, and advocated an early state convention in the next year so that the party could continue its good work toward the election of 1864 .

A series of jollification meetings were held throughout the state at which Vallandigham was the most popular speaker. Stung by his own personal defeat, ${ }^{2}$ which he felt had been brought about by the machinations of a party no longer in sympathy with the popular will, he could still consider the election as a whole to be an endorsement by his old constituents. It was proper that he should be taken care of by his party, and at a meeting held at Hillsboro, October $22 \mathrm{~d}$, a resolution was adopted proposing him as

'Ohio Statesman, Oct. 14th.

${ }^{2}$ Cf. supra, p. 108. 
the most suitable candidale for governor in I863. A few days after the election, the editor of the Dayton Empire ${ }^{1}$ was killed by a neighbor as a result of a quarrel brought on through a combination of private and political affairs, and this gave the Democrats an added count against their opponents. He was mourned as "the first martyr to the cause of free speech and a free press." Vallandigham, speaking at a meeting held in Newark, characterized the murder as one of the sad results of the gospel of hate which had been for years preached by many of the clergy and instilled by the abolition press. Olds, still in prison, was elected to the legislature to fill a vacancy caused by the death of the representative from his county. The names "Butternut" and "Copperhead" applied to the Democrats during the campaign as epithets of reproach, were assumed with pride by the "Vallandighammers." Volunteering almost ceased in the state, and desertions from the army became frequent.

In the midst of this glorification, the last session of the Thirty-seventh Congress convened, and Vallandigham and his associates returned to continue their fight for the "Union as it was" and the constitutional rights of their fellow citizens before the seemingly discredited majority. On the first day of the session, $\mathrm{C}$ )x brought up the subject of military ar:ests by offering a resolution that the House "condemn all such arrests as unwarranted by the Constitution and laws of the United States, and as a usurpation of power never given up by the people to the rulers." 2 A few days later Vallandigham presented a series of resolutions providing that if anyone should advise the acceptance of terms of peace on any other basis than the integrity of the

'J. F. Bollmeyer.

'Cong. Globe, 37th cong., 3d sess., p. 2. 
Union, or should attempt to pervert the war to one of conquest or to abolish slavery, or should propose by Federal authority to extinguish any of the states, or make any move toward the declaring of a dictatorship, he should be guilty of a high crime against the Constitution and the Union. ${ }^{1}$ The majority, however, under the somewhat despotic leadership of Thaddeus Stevens of Pennsylvania, showed no disposition to compromise, or waver in their support of the President's actions. A bill introduced by Stevens was pushed through the House, authorizing the President to suspend the privilege of the writ of habeas corpus in any case in any part of the United States, and giving to all persons who were concerned in making military arrests, protection against indictment. ${ }^{2}$. This summary manner of validating such questionable proceedings called forth a formal protest from the minority, signed by thirty-six members. ${ }^{3}$ The Senate, a few weeks later, passed a conscription bill providing for the division of the country into enrollment districts, each in charge of a provost-marshal who was to superintend the drafting of troops and report on all treasonable practices within his district. ${ }^{4}$

On these two measures the two parties crossed swords during the session, and when the bills were finally enacted into law on March $3 \mathrm{~d}$, the aay before adjournment, they showed the effects of the powerful attacks of the minority. The act concerning military arrests was modified to provide that lists of all political prisoners held at the time should be furnished to the judges of the circuit and district courts of the United States, and that where a grand jury had adjourned without finding an indictment against any such person, the judge should forthwith discharge him on his

${ }^{1}$ Cong. Globe, 37th cong., 3d sess., p. 15.

'Ibid., p. 21. $\quad{ }^{3}$ Ibid., p. 165.

'Ibid., p. 1002. 
taking on oath of allegiance. Any order issued under the authority of the President, however, should be a sufficient defense in any court in any action, civil or criminal, for any arrest made by virtue of such order. Finally, any such action begun in a state court might be transferred to the United States courts. ${ }^{1}$ The conscription act as passed was shorn of the clause regarding "treasonable practices," and made to deal only with the raising of troops. ${ }^{2}$

Vallandigham assumed the leadership of the Peace element in the opposition to this legislation. Ably supported by his colleagues, Cox, Pendleton and C. A. Whitc, and by Voorhees of Indiana, his thorough mastery of the rules of the House enabled him to wield the full power of the minority in every stage of the proceedings. On January 14,1863 , he delivered one of the strongest speeches of his career on the war and the restoration of the Union. Holding that not slavery but abolition was the cause of the war, he "blessed God that not the smell of so much as one drop of its blood" was upon his garments. The war for the Union had been "a most bloody and costly failure". The President had confessed it in his Proclamation, and now it was to be changed to a war for the negro. He denied the doctrine of an "irrepressible conflict". The Union part slave and part free was one of the compromises of the Constitution. If the East continues until a separation be forced, "the day which divides the North from the South, that self-same day decrees eternal divorce between the East and the West". Asking if the war should continue, he answered: "No, not a day, not an hour. What then? Shall we separate? Again I answer, no. What then?" He would stop fighting and declare an armistice. reduce the armies to a peace footing, and when passion had

\footnotetext{
'U. S. Statutes at Large, vol. xii, p. 755.

${ }^{2}$ Ibid., p. 7.3 I.
} 
cooled, settle the question on the basis of the original Constitution, giving each section the power to protect itself within the Union. He would accept the offer of the Emperor of France ${ }^{1}$ for friendly mediation, " as the speediest, easiest, most graceful mode of suspending hostilities." 2 Later on in the session, when the conscription bill was under discussion, he made a vigorous attack on its provisions. Recalling to the members of the majority that the proposal to draft was a confession that the people of the country were against the wvar, he denounced the new crime of "treasonable practices" as being not only unknown to the Constitution, but as sanctioning the arbitrary arrests against which the people had spoken so decisively at the last election. He asked only that the majority give the pcople the rights guaranteed by the Constitution, "till at the time and in the manner appointed by the Constitution and law, we shall eject you from the trusts you have abused, and the seats of power you have dishonored, and other and better men shall reign in your stead." 3

The Peace Democrats throughout the state assumed an attitude similar to that taken by their spokesmen in Congress. While many in the party were not in sympathy with the views of Vallandigham regarding peace, all could unite on a common ground in opposing the prosecution of the war for the freeing of the negro, and in championing the cause of personal liberty. The issuing of the final Proclamation of Emancipation on January Ist, left no doubt as to the changed character of the war, while the failure of the at-

'Horace Greeley was laboring to bring about mediation by Louis Napoleon, and had solicited Vallandigham's aid in the matter. See Rhodes, Hist. of the U.S., vol. iv, p. 222. Vallandigham and Cox both advocated this in their speeches.

${ }^{2}$ Cong. Globe, 37th cong., 3d sess., App., p. 55.

'Ibid., App., p. I72. 
tack on Vicksburg and the disaster at Fredericksburg indicated the probable truth of the assertion that the South could not be conquered. The disruption in the ranks of the Union party was accompanied by a corresponding solidification of the Democracy.

Olcls, released from prison only a few weeks before, ${ }^{1}$ was escorted from Lancaster to take his seat in the legislature by a long procession of the Democrats of his county, and was tendered an enthusiastic reception on his arrival at Columbus. George L. Converse, the minority leader in the lower house, in clelivering the address of the occasion, held that the enthusiasm was not a mere personal demonstration, but one for principle-because a usurper had seen fit to cause his arrest in violation of the express provisions of the Constitution.

It is because you had the independence and the manhood to prefer to sacrifice your life upon the altar of your country, to prefer the slow tortures of martyrdom in a political bastile, rather than yield to this abolition god your Constitutional rights and Constitutional liberty as an American citizen.

In his response, Olds expressed the hope "that the despotism of Abraham Lincoln and 'renegade' Tod is fast coming to an end. The demonstration of today shows that the American people are aroused to a sense of their true conclition." 2

On January 8th, the Democrats held their usual Jackson day banquet at Columbus, and the burning questions of the times furnished stimulating themes for the addresses. Thurman responded to the sentiment, "Civil liberty and its great bulwark, the Writ of Habeas Corpus." Jewett, speak-

${ }^{1}$ Cf. supra, p. 106.

${ }^{3}$ Crisis, January $7,1863$. 
ing on the subject, "Executive Proclamations," said he never regretted his defeat for governor until Lincoln had proclaimed martial law, and that if he had been in office at the time he would have issued a counter proclamation telling the administration that though Ohio was loyal to the government, the Constitution and the old flag, her people had rights and would not tamely submit to have them violated, outraged and destroyed. Medary spoke on "Freedom of Speech and of the Press," Olds and McGregor on "The Lincoln Bastile," and Critchfield, the attorneygeneral elect, on "The Constitution as it is, the Union as it was and the Negroes where they are." As reported in the press the tone of the speeches was extremely radical, that of Critchfield being especially so. He charged the administration with changing the war from its original purpose to a " nigger crusade," and held that if the incessant violations of the Constitution continued, if the rights of the citizens were wantonly trampled upon and their civil liberties destroyed by the administration, he did not believe the people would care whether Lincoln or Jeff Davis were in Washington. ${ }^{1}$ Because of these remarks, the Senate refused to pass the usual resolution informing him of his election. $^{2}$

In the legislature the same defiant attitude was displayed, and while the Unionists were wrestling with the Senatorial question and the Emancipation Proclamation, they were also compelled to contend against the persistent attacks of a troublesome minority. The violation of personal rights through executive usurpation, and the threatened overrunning of the state by the freed negroes were

${ }^{1}$ Accounts of the meeting are given in the Ohio Statesman, Jan. 9th, and in the Crisis, Jan. I4, 1863.

'Senate Journal, 1863, p. 12. 
topics under almost constant discussion throughout the session.

Governor Tod assumed full responsibility in his message for the arrests of the preceding year, asserting that two had been made at his own request. ${ }^{1}$ He recommended that the treason act of $186 \mathrm{I}$ be so modified as to include the offense of interfering with enlistments, thus enabling the local authorities to deal with such offenders in the future. On the second day of the session, Dresel, a Peace Democrat from Franklin county, offered a resolution calling for the appointment of a select committee to inquire what citizens of the state had been imprisoned, the charges against them and by whom made, what provision had been made for their trial, on what terms they had been released and what the governor had done to protect the citizens of Ohio against unlawful arrests and to secure to them the constitutional right to a speedy and public trial by an impartial jury. ${ }^{2}$ A counter resolution was offered from the Union side to instruct the judiciary committee to report a bill for the more effectual suppression of disloyalty to the government within the state, and to inquire whether any member of the House had been engaged in any treasonable practices or of giving aid or encouragement to the enemies of the government. ${ }^{3}$ In his defense Olds asked that this committee be instructed to inquire whether any member of the House had been guilty of treason within the meaning of the Constitution of the United States, and to ascertain from

'Tod wrote to the Secy. of State, July 29, I862: "I have most satisfactory evidence that Edson B. Olds, a former member of Congress, is doing all the mischief he can. He is a shrewd, cunning man, with capacity for great mischief, and should at once be put out of the way. I have, therefore, to advise that you direct Marshal Sands to arrest him and confine him at Fort Warren, at least until I shall have succeeded in raising my regiments." House Journal, 1863, App., p. 7.

\footnotetext{
${ }^{3}$ House Journal, i863, p. 7.

${ }^{3}$ Ibid., p. 8.
} 
the governor whether either of the persons whose arrest he recommended were members of the House, and if so, that he be required to produce the evidence on which his action was based. ${ }^{1}$ The first of these resolutions was adopted with the omission of the clauses asking by whom the charges were made and what the governor had done to protect the citizens. $^{2}$

The committee as appointed consisted of three Unionists and tivo Democrats. It collected evidence on all the cases, and reported on April I4th, the last day of the session. ${ }^{3}$ Considering the demand of the parties for a trial by jury and its refusal, it held that, " under our system of government there can be no trial by jury for offenses committed, except upon the charge of some act specifically declared by statute to be punishable as a crime;" and since discourageing enlistments and exciting disobedience to a draft were so entirely unknown prior to the war, no statutes had been enacted on the subject. Consequently, the courts had no jurisdiction and the guaranties of the Constitution did not apply. In the emergency, two alternatives were open to the government, either to suffer its arm to be paralyzed with impunity by seditious and disloyal practices and speeches, which were not indictable by statute, and hence not triable by jury, or to curb and restrain these practices by military power. The government had chosen the course of firmness,

\footnotetext{
'House Journal, 1863, p. 9.

${ }^{2}$ Ibid., p. I45.
}

${ }^{3}$ The committee found that the following citizens of the state had been arrested by military authority: Edson B. Olds of Fairfield county; Peter N. Reitzel and Archibald McGregor of Stark county; Judge L. W. Hall and Daniel Tuttle of Crawford county; John W. Kees of Pickaway county; Daniel M. Allen of Columbiana county; Samuel Flowers and Bethuel Ruberts of Champaign county; Warren Stanton of Ashtabula county; and Alexander Wallace of Brown county. The report of the committee with the evidence may be found in the appendix of the House Journal for 1863 . 
and under the clause of the Constitution providing for the suspension of the privilege of the writ of habcas corpus, promoters of sedition were temporarily confined. The action was fully justified, the committee held, under this clause, while the recent acts of Congress would provide for such cases in the future.

In the meantime, Converse introduced a bill, March 24th, making the arrest of any white person within the state by military authority or in any way without a iegal process, a felony. ${ }^{1}$ When it came up for discussion a few days later, a substitute was presented and passed which modified the kidnapping law of 1835 , so as to except from its provisions persons carried out of the state in pursuance of a military order of the constituted authorities of the state or the United States. After the measure had thus been turned from its original intention, the Democrats suggested various titles for it such as: "An act to relieve the Republican party from violations of a criminal law," and "An act to abdicate the sovereignty of the State of Ohio and transfer the same to the President of the United States." The Senate passed the bill as it came from the House. ${ }^{2}$ An older act of I8I I prohibiting the sending of any citizen of Ohio to any place outsicle the state for an offense committed within its limits except in certain specified instances, was modified so as to include within its exceptions persons sent from the state " in pursuance of any military orcler of the President of the United States." 3 By this legislation, the Unionists indicated their determination to support the administration on the matter of military arrests as making for a vigorous prosecution of the war.

During the discussion of the resolution pledging anew

${ }^{1}$ House Journal, 186.3, p. 397.

2 Laws of Ohio, vol. 1x, p. 72.

'Ibid., p. II5. 
the support of the state to the government, and deprecating any attempt to divide the loyal states with the ultimate design of attaching any portion of them to the Southern Confederacy, ${ }^{1}$ Dresel offered as a substitute a series of resolutions which formed part of the platform adopted by the Democratic party of Connecticut a few days before. They provided that the government of the United States should be supported in the full constitutional exercise of its powers, yet they avowed that "the liberties of the people are menaced by Congress and Federal usurpation, and can only be preserved by the energetic action of State authority, and we are determined to maintain and defend the honor of our State and the rights of her people." The conscription act was held to be "subversive of the sovereignty and rights of the States, and designed to make them mere dependencies upon the central government, unconstitutional in its provisions, and dangerous to the liberties of the people." The national banking system was held to be based upon an unconstitutional and irredeemable issue of paper currency, and designed to establish a vast central money power unknown to the Constitution. The Emancipation Proclamation tended "to disgrace our country in the eyes of the civilized world, and carry lust, rapine and murder into every house in the slaveholding states." The recent acts of the Federal administration were recited, and all declared " arbitrary and unconstitutional, subverting the Constitution, Federal and State, invading the reserved rights of the people and the sovereignty of the States." 2

This extreme expression of the doctrine of state rights was supported when Dresel introduced it by only ten of the minority party. The indignation felt by the Unionists led to the adoption of a resolution of censure declaring

${ }^{1}$ Cf. supra, p. I12.

House Journal, 1863, p. 363. 
Dresel " a promoter of sedition, an advocate of disunion and an enemy to his country."

The Democrats also continued their agitation against the immigration of negroes into the state. Attempts were made to have the bills which had been postponed at the preceding session ${ }^{1}$ brought up for consideration, and also to have a resolution adopted providing for the submission of a constitutional amendment on the subject to the voters at the next annual election. ${ }^{2}$ In order to find out if the question was as serious as the Democrats were representing it, the auditor of state was directed by resolution to ascertain from the county auditors the number of colored persons immigrating into the various counties since March I, I86I, and the place where each resided before coming into the state. $^{3}$ Reports from fifty-seven counties were obtained which showed a total of I 384 immigrants. Allowing the same proportion for the other counties, the whole increase was estimated at about 2000. Of those reported, I250 came from the South, mostly from the border states." This seemed to the majority sufficient proof that the question was not a serious one, and they refused to take any action on it.

The Democratic meetings which had been begun after the fall elections, were continued through the winter and spring while the party leaders were urging their opposition to the acts of the administration, in Congress, in the state legislature, and through the press. The addresses and resolutions adopted at these meetings contained the same denunciations of executive usurpation and the abolitionizing of the war. Vallandigham formally announced his can-

${ }^{1}$ Cf. supra, p. 97.

${ }^{2}$ Senate Journal, p. 4I.

${ }^{3}$ House Journal, I863, p. 265.

4 Ibid., p. 476 . 
didacy for the governorship in January, ${ }^{1}$ and at many of the meetings he was endorsed. The idea of holding a national Democratic convention, which was suggested early in the year by the Chicago Times, also found much favor.

On the night of March $5^{\text {th }}$, the office of the Crisis was mobbed by soldiers from Camp Chase, just outside of Columbus, and its contents were destroyed. The paper had been excluded from circulation in some of the states and in many of the regiments in the field on account of its seemingly treasonable editorials, and the feeling in the army was very bitter toward it. Medary was out of the city at the time of the attack, and on his return the next day he was met at the depot by a large number of the Democracy and escorted to his home, where Thurman expressed the sympathy of the party for his loss. On the next day a "law and order meeting" was held in Columbus, and the authorities were called upon to punish the guilty parties. In the resolutions adopted, the "outrage" was declared to be

the natural consequence of that fatal disregard of the Constitution and laws which has marked the course of our Administration, Federal and State, ever since the war began. . . . We now say to all whom it may concern, not by way of threat, but calmly and firmly, that we will not surrencler these rights, nor submit to their forcible violation. We will obey the laws ourselves, and all others must obey them. ${ }^{2}$

An investigation was made by the officers of the regiment to which the soldiers belonged, but no one was punished for the offense. This was the beginning of a series of such attacks which continued throughout the war. While they were condoned by the military authorities, they added a

${ }^{1}$ Letter to Dem. central committee of Jefferson county. Cincinnati Commercial, Jan. 28, 1863.

2 Ohio Statesman, March 8th. 
new plank to the platform of the Peace Democracy, that of retaliation in kind. The Dayton Empire said:

If we have no protection under the Constitution and laws, then we must protect ourselves by every power and right vested in us as freemen. We must make the property of our opponents security for our own. . . . For every drop of blood spilled by abolition mobs, let theirs flow in retaliation. ${ }^{1}$

After Congress adjourned on March 4th, and the Ohio members returned to their homes, the contest was waged within the state with all the resources of both parties. With petitions coming in from the soldiers in the field, denouncing the Democrats as traitors, and calling on the friends of the Union to remain loyal, with the activity of the secret organizations opposed to the war, and the corresponding activity of the Union Leagues to keep up the war spirit, and with the quarreling over offices among the members of the Union party, the situation at times looked very serious for the Union cause. ${ }^{2}$ Each party tried to outdo the other in arranging meetings and arousing enthusiasm.

The sequel to the Olds affair ${ }^{3}$ came with the arrest of Governor Tod in his office at the State House, April 2d, by a cleputy sheriff of Fairfield county, on a warrant issued by Van Trump as common pleas judge charging him with the crime of kidnapping. In December, Olds had appeared before a justice of the peace and made affidavit that Stoughton Bliss of the governor's staff, together with two others, had arrested and carried him out of the state unlawfully. Bliss was placed under bond to appear for trial. Later he petitioned under the act of March $3 \mathrm{~d}$, to have his case

${ }^{1}$ Editorial, March IIth.

${ }^{2}$ Stanley Matthews wrote to Chase, February roth, that he had been home shortly before and was surprised at the boldness of the leading Democrats against the government. Chase Papers, MS.

${ }^{3}$ Cf. supra, p. 106 . 
transferred to the United States Circuit Court at Cincinnati. This was refused by Van Trump on the ground that the case arose in the execution of a mere order of the President, which was unauthorized by any act of Congress and was in direct conflict with the constitution of the state and with the kidnapping act of 1835 . Indictments were consequently brought against Bliss and also against the governor. A warrant was issued for Tod's arrest, and a deputy sheriff was sent to Columbus. It happened that at the time of his arrival the Supreme Court was in session, and Tod applied to Judge Gholson, who released him on a writ of habeas corpus on his giving bond to appear in the Fairfield county court on June Ist. The bill to amend the kidnapping act had just gone from the House to the Senate when the news of Tod's arrest became known, and an attempt was made to call the Senate together after it had adjourned, to pass the measure. This could not be done, and the bill was not enacted until April 9 th. $^{1}$

In June, the governor appeared before the court and obtained a continuance in the criminal case, but he was served with papers in a civil suit by Olds for one hundred thousand dollars damages. On a petition made later in the year to have this case transferred to the United States court, Van Trump held the act of March 3 d unconstitutional, ${ }^{2}$ and refused to grant the petition. ${ }^{3}$

${ }^{1}$ Cf. supra, p. I53.

${ }^{2}$ Crisis, November 25,1863 .

${ }^{3}$ On this refusal of Van Trump to transfer the case, the legislature at its next session passed an act, March 17, I864 (Laws of Ohio, vol. 1xi, p. 3I), providing for the transfer of such prosecutions to the United States courts in compliance with the Indemnity act. It was to be the duty of the state court to certify the suit to the circuit court of the United States of the district in which the suit was pending. In case of refusal, the Supreme Court of the state was authorized to compel its performance by writ of mandamus. In accordance with this act, the Supreme Court issued such a writ in June, 1865, and the case went to the United States court at Cincinnati, where it slept. In 1867, after the Democratic success of that year, an attempt was made to revive it, but without success. 
THE ARREST AND TRIAL OF VALLANDIGHAM

With feeling in the state thus at high tension, an added element of disturbance was injected by the assignment of General Burnside in April to the command of the Department of the Ohio, composed of the states of Ohio, Kentucky, Indiana, Illinois and Michigan, with headquarters in Cincinnati. Fresh from his recent disaster at Fredericksburg, he had lost prestige with the country, and his efforts to deal with the "rebel sympathizers" in the states under his control were opposed with much bitterness by the Democrats. At a large mass meeting held at Hamilton, Ohio, on March 23d, where Vallandigham, Pendleton and Voorhees were the principal speakers, the first named took for his text a

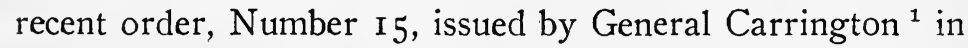
Indiana under the direction of Burnside, forbidding the carrying of arms. He contrasted it with what he called General Order Number I, signed by George Washington, "The right of the people to carry and bear arms shall not be infringed," and with General Order Number 2, from the Constitution of the state, "The people have a right to bear arms for the defense of themselves in the state." Whenever an attempt was made by the party in power to perpetuate their existence by unlawful means, then he was for resistance. Those before him gave evidence that the administration would not dare to trifle with twenty-five millions of people. Pendleton was for opposing the administration by peaceable means, by free speech, a free press and the ballot box, but if these were taken away and mob violence imposed, then let their opponents beware. This was the beginning of that open defiance to the orders of General Burnside which culminated in the arrest and removal of

${ }^{1}$ Under Burnside, Gen. Carrington was in command of the district of Indiana with headquarters at Indianapolis. Gen. J. D. Cox was in command of the district of Ohio. 
Vallandigham. Resolutions were adopted at this meeting, calling for a national convention to be held at Indianapolis on the third Tuesclay of May, endorsing Vallandigham for governor, and eulogizing Thomas H. Seymour, the Democratic candidate for governor of Connecticut. ${ }^{1}$

On April I 3 th, Burnsicle issued his General Order Number 38 , which was destined to bring the Peace Democrats to the high ticle of their opposition. Finding a strong prosouthern element in Cincinnati who were active in assisting their friends by information and provisions, the order provicled that, "hereafter all persons found within our lines who commit acts for the benefit of the enemies of our country will be tried as spies or traitors and, if convicted, will suffer death." After a specific enumeration of the classes of persons referred to, it continued:

The habit of declaring sympathy for the enemy will not be allowed in this department. Persons committing such offenses will be at once arrested with a view to being tried as above stated, or sent beyond our lines into the lines of their friends. It must be distinctly understood that treason expressed or implied will not be tolerated in this department. ${ }^{2}$

A provost court was established, and the trial of individuals who were found committing overt acts forbidden by its provisions was begun. ${ }^{3}$

The order immediately became the target for the shafts of the Democratic orators, especially Vallandigham, who pronounced it another link in the chain of despotic acts of Lincoln and his minions, and openly defied it. Burnside, with all the instincts of a military commander, resented this,

${ }^{1}$ Crisis, April 1, 1863 .

${ }^{2}$ The Trial of Hon. C. L. Vallandigham by a Military Commission. Cincinnati, I863, p. 7.

${ }^{3} \mathrm{~J}$. D. Cox, Military Reminiscences, vol. i, p. 455. 
and determined, should the offense be repeated, to arrest the chief offender.

On May Ist a mass meeting of the Democracy of Knox county was held at Mount Vernon. This meeting was characteristic of the times, being attended by an immense number of people ${ }^{1}$ and lasting the entire day. The decorations consisted of American flags and butternuts, while pins made of the heads cut out of copper cents were worn conspicuously. Addresses were delivered simultaneously from four stands, the principal orators of the day being Vallandigham, Cox and Pendleton. While the last two were somewhat temperate in their remarks, Vallandigham rose to the height of invective in his denunciation of the administration. He held that the intention of those in power was not to effect a restoration of the Union, but to erect a despotism; that the war had been turned from its original purpose, and was being waged "for the liberation of the blacks and the enslavement of the whites"; that it was the purpose of the administration to suppress or prevent such meetings; and that military marshals were about to be appointed in every district, who would act for the purpose of restricting the liberties of the people. He was a freeman, however, and did not ask David Tod nor Abraham Lincoln nor Ambrose E. Burnside for his right to speak; his authority for doing so was higher than Order Number $38-$ it was Order Number I, the Constitution. Order Number $3^{8}$ was a base usurpation of arbitrary power; he " despised it, spit upon it, trampled it under his feet." 2

Burnside sent two of his officers in citizens' clothes to

${ }^{1}$ The Democratic papers estimated the number at 20,000 .

${ }^{2}$ As this speech was similar to those Vallandigham had given in several places during the preceding weeks, no complete report of it was printed in the papers. The author has followed the account given by Burnside's officers at the trial. 
attend the meeting and takes notes on the speeches, and these reports furnished him with the evidence he desired. Vallandigham was arrested at his home in Dayton early in the morning of May 5th by a company of soldiers, and taken to Cincinnati. ${ }^{1}$ A military commission had been appointed by Burnside some days previous, and before it, the prisoner was arraigned on the charge of, " publicly expressing, in violation of General Order No. 38 . . sympathy for those in arms against the government of the United States, and declaring disloyal sentiments and opinions, with the object and purpose of weakening the power of the government in its efforts to suppress an unlawful rebellion." Denying the jurisdiction of the commission, Vallandigham refused to plead, and the plea of " not guilty" was entered for him. Pugh and Pendleton were present to advise with him, but to avoid the appearance of waiving the question of jurisdiction, they did not appear at the trial. The only witnesses examined were the two officers and Cox.

At the close of the testimony, Vallandigham submitted a protest holding that since he was not in the land or naval forces of the United States, nor in the militia in actual service of the United States, he was not triable by a military commission, but subject to all the provisions of the Constitution in regard to trial, and further that the "alleged" offense was not known to the Constitution of the United States, nor to any law thereof.

The trial lasted for two days closing on May 7 th. At once, before the finding of the commission was announced, Vallandigham, through his counsel, Pugh, applied to Judge

${ }^{1}$ Burnside did not consult with his subordinates nor with lawyers, but sent his own aide with the soldiers to make the arrest. He did not want to take any chances of being baffled, or to give the opportunity for raising a mob. See J. D. Cox, Military Reminiscences, vol. i, p. 460 . 
Leavitt of the United States Circuit Court at Cincinnati for a writ of habeas corpus, with the idea of testing the lawfulness of his arrest and trial. A hearing was appointed, and the question was elaborately argued during several days. A statement was admitted from General Burnside giving his reasons for the issuance of the order under which the arrest was made. In it he asserted that it was his duty and the duty of his soldiers not to indulge in any wholesale criticism of the policy of the government whereby the power of the army would be weakened. $\mathrm{He}$ had been placed over the Department at a time when Kentucky, one of the states composing it, was actually invaded and when three others had been threatened. If it was his duty and the duty of the troops to avoid saying anything that would weaken the army, it was equally the duty of every citizen in the Department to avoid the same evil. If that were not done, it was his duty to use all the force in his power to secure the desired end. Only the constituted authorities of the government of the United States could inaugurate a legally valid war policy, and if the people should disapprove that policy, they might change those authorities at the proper time and by the proper method. "Let them freely discuss the policy in a proper tone; but my duty requires me to stop license and intemperate discussion which tends to weaken the authority of the Government and the army." So long as he possessed any power, it would be used in defense of the government "on all occasions, at all times and in all places within the Department." 1

Pugh, in his argument, demanded the granting of the writ as of right, since the President had not exercised his authority under the conscription act of suspending its

${ }^{1}$ Gen. Burnside was represented at the hearing by the U. S. District Attorney, Flamen Ball, and by Aaron F. Perry. 
privilege, and protested against argument as to whether or not it should issue. 'He denied that Burnside's duties as major-general gave him sole charge of the maintenance of Federal authority in that neighborhood, with the right of taking away the liberties of the citizens. Holding an office created by Congress, he could not, therefore, make a "law" which Congress could not make, abridging the freedom of speech. The prisoner, being a citizen not in the military service, was entitled to all the guarantees of the Constitution, under which there could be no legal arrest except by warrant. In other words, he would limit the authority of the general to the control of his troops as provided by the Articles of War.

After hearing the arguments for both sides, Judge Leavitt rendered his opinion. He held that the writ was not grantable as of right, but only on sufficient showing that it ought to issue; and its refusal would be justified if the court was satisfied that the petitioner would not be discharged upon a hearing after its return. In this case, Burnside had acted as agent of the President, whose powers as commander-in-chief of the army were not defined by the Constitution or by statute, and hence were not reviewable by the courts. IVhile the court had the power to grant the writ, it could not, on its return, go into the question of the jurisdiction of the military commission, and hence could not discharge the prisoner. This, therefore, was sufficient ground for refusing the request. To the President alone, the commander must answer for his official conduct. This conclusion was fortified, the judge held, by the fact that the legislature at its last session had enacted statutes by which the validity and legality of arrests in the state made under military authority were distinctly sanctioned. ${ }^{1}$

1 The whole proceedings of the trial was published in: The Trial of Hon. Clement L. Vallandigham by a Military Commission, Cincinnati, 1863 . 
The finding of the commission, which had been held back awaiting the action of the court, was made public on May I6th. The prisoner was found guilty of the charge, and sentenced "to be placed in close confinement in some fortress of the United States, to be designated by the commanding officer of this Department, there to be kept during the continuance of the war." Burnside approved the sentence, and directed that the place of confinement be Fort Warren in Boston harbor. Three days later, the President commuted the sentence by directing that Vallandigham be sent under guard "to the head-quarters of General Rosecrans, to be put by him beyond our military lines, and that in case of his return within our lines, he be arrested and kept in close custody for the term specified in his sentence." Accordingly, on May $22 \mathrm{~d}$ he was put on a steamer and taken down the river, and on the $25^{\text {th }}$ he passed over into the Confederate lines.

The whole procedure in regard to Vallandigham is generally conceded to have been a serious mistake both legally and politically. The President's proclamation of September 24, 1862, which made persons guilty of disloyal practices subject to martial law and liable to trial by courts martial or military commission, had not been formally revoked, but the authority of the Executive to suspend the writ of habeas corpus had been in dispute since he first exercised it at the beginning of the war. ${ }^{1}$ And this proclamation was superseded by the act of March 3, 1863, by the terms of which Vallandigham should have been delivered over to the United States courts and his case presented to a grand jury. Judge Leavitt, however, took no account of this act in delivering his opinion, but rested it

'See McPherson, History of the Rebellion, p. I55 et seq.

'So held in the Milligan case, 4 Wallace, p. I33. Cf. also Rhodes, History of the United States, vol. iv, p. 248. 
solely on the war power of the President, which, he held, could be exercised without a prior, formal proclamation of martial law. Burnside's assumption that, since war was being waged in Kentucky and had been threatened in Ohio some months before, ${ }^{1}$ he was justified in considering the whole Department as the scene of actual military operations and hence subject to martial law, can scarcely be sustained, as the civil government was in no way suspended, and the courts were open and in operation. The whole question of the authority of military commissions was passed upon by the Supreme Court in December, I866, after the excitement of the war had passed. It was then held that a person arrested after the passage of the act of March $3^{d}$ was entitled to his discharge, if not indicted by a grand jury convened at the first subsequent term of the United States court held in the district in which the prisoner was held; and also that military commissions had no jurisdiction over criminal offences committed by a person not in the military or naval service of the United States, in a state not the actual theatre of war and where the regular courts were open and in the proper and unobstructed exercise of their judicial functions. ${ }^{2}$

Lincoln did not desire the arrest of Vallandigham, ${ }^{3}$ and was much concerned about the indiscretion of his overzealous subordinate. Yet, through the Secretary of War he gave his approval of the act, ${ }^{4}$ and the Cabinet was in favor

${ }^{1}$ Kirby Smith had threatened to invade the state in September, I862.

${ }^{2}$ Ex parte Milligan, 4 Wallace, p. 2.

${ }^{3}$ A. K. McClure, Reminiscences, p. 228.

"Stanton sent a message to Burnside, May 8th: "In your determination to support the authority of the Government and suppress treason in your Department, you may count on the firm support of the President." Official Records of the Rebellion, series i, vol. xxiii, pt. ii, p. 316 . 
of upholding it. ${ }^{1}$ However, when Burnside issued a further order, June Ist, prohibiting the circulation of the New York World in his Department, and suppressing the publication of the Chicago Times, the President, on the request of a mass meeting of the citizens of Chicago, directed him to revoke his action. A few days later Secretary Stanton requested Burnside not to arrest civilians or suppress newspapers without conferring first with the War Department. ${ }^{2}$

\section{THE CAMPAIGN OF 1863}

The case had a most marked effect on the politics of the year, not only in Ohio, but throughout the North, and brought the Peace Democracy into a prominence it would not otherwise have reached. During the early months of the year there was considerable discord between the radical and moderate elements of the party in the state. While immense crowds assembled at the Democratic mass meetings, and the enthusiasm ran high, yet these crowds did not measure the strength of Vallandigham. Many who were opposed to his views were attracted to his speeches by the fascination of his oratory. It is probable that only a small minority within the party were willing to support his plan for securing peace. After he had announced his candidacy, the moderate element started a movement to secure the nomination of Jewett, and this soon became so formidable as to threaten a disruption of the party. ${ }^{3}$ At a meeting of the state central committee, March $25^{\text {th }}$, an attempt was made to bring the two elements together and arrange some

${ }^{1}$ Lincoln, Complete Works, vol. ii, p. 342.

${ }^{2}$ O. R., series i, vol. xxiii, pt. ii, p. 386 , and J. D. Cox, Reminiscences, p. 463. Gen. Cox is inclined to criticise the administration for not formulating a rule for its military officers to guide them in such cases.

${ }^{3}$ The Plain Dealer, Statesman and Enquirer supported Jewett. 
concerted plan of action against the arbitrary measures and usurpations of the administration, but the committee being about equally divided, no action could be taken. ${ }^{1}$ The falling-off in the Democratic vote in the spring elections and the defeat of Seymour in Connecticut tended further to reflect discredit on the radical platform, and to increase the probability of Jewett's nomination.

But the feeling of indignation aroused by the arrest of Vallandigham tended to dissolve all opposition. His prominence gave the case a wide notoriety, while the punishment inflicted clothed him with the character of a martyr and called for his vindication. Just before his departure from Cincinnati, he sounded a trumpet call to action in a letter addressed to the Democracy of Ohio. Banished from his native state "for no crime save Democratic opinions and free speech," and about to go into exile "by the compulsion of an arbitrary and tyrannic power," he still recognized his allegiance to his own state and government. Every sentiment of attachment to the Union and devotion to the Constitution would abide unchanged until his return. In the meantime he did not doubt that "the people of Ohio, cowering not a moment before the threats or the exercise of arbitrary power," would "prove themselves worthy to be called freemen." ${ }^{2}$

The first formal note of protest came from a meeting held at Albany, N. Y., on May I6th. Governor Seymour, unable to be present, sent a letter characterizing the action of Burnside as clearly signifying the establishment of military despotism. ${ }^{3}$ Resolutions were adopted and transmitted to the President denouncing the arrest of Vallandigham as an assumption of power which struck a fatal blow at the su-

${ }^{1}$ Crisis, April rst.

${ }^{2}$ Life of Vallandigham, p. $296 . \quad{ }^{3}$ Ibid., p. 289. 
premacy of law, and calling upon the President to reverse the action of the military tribunal. ${ }^{1}$

While this was the voice of the conservative Democracy of New York, speaking immediately after the sentence had been made public and before it had been commuted, the Peace element pronounced its disapproval in less measured terms after the prisoner had been banished. At a large meeting held in New York city, June $3 \mathrm{~d}$, for the purpose of enunciating anew the doctrines of peace, an address and resolutions were adopted expressing the state-rights doctrine in its most extreme form. They declared that the Virginia and Kentucky resolutions were the fundamental principles of the Democratic party; that a war could not be sustained against sovereign states; that the war in its inception and further continuance being contrary to the Constitution, must fast consume all the elements of union, and had already become a failure. The trial of citizens by courts martial was denounced as " monstrous in theory and execrable in practice." It was hoped that the people of Ohio would have the opportunity of passing condemnation of the arrest of Vallandigham by electing him the next governor of the state. Finally, the resolutions called for a suspension of hostilities and for two conventions, one of the seceded states, and one of the states still adhering to the Union, to determine by what mode the contending sections should be reconciled. ${ }^{2}$

While the Union Leagues endorsed the finding of the military commission, and demanded that the sentence be carried out, there was a considerable feeling among the moderate Unionists that it worked a great injustice, and it was on the suggestion of their press and the advice of Governor

${ }^{1}$ McPherson, History of the Rebellion, p. 163.

${ }^{2}$ New York Times, June 4, 1863. 
Tod $^{1}$ that the President sent Vallandigham into rebel territory and thus turned the affair into something of a joke. However, it revived the whole subject of arbitrary arrests, and presented again the issue of personal liberty on which the Democrats had won success in the elections of the previous year, with its champion a martyr to the cause.

June IIth was the date fixed for the holding of the Democratic state convention. During the preceding days the tide of popular opinion set in with increasing strength until it became a clamor on the part of the masses of the party for the nomination of Vallandigham. Jewett, seeing the drift of sentiment, withdrew from the field. A last effort was made by the moderate element to turn the tide by bringing forward General McClellan as a candidate, ${ }^{2}$ but he refused to permit his name to be used.

The convention assembled at Columbus amid the greatest enthusiasm. In point of attendance it had never been equaled in the state. ${ }^{3}$ Ex-Governor Medill ${ }^{4}$ presided, and in his speech to the delegates said that Vallandigham must be brought back.

If they are not deaf, your recreant rulers will be warned by this tremendous demonstration, that the people are no longer to be trifled with in their dearest rights and most sacred privileges, and the powers who have aroused you, will quake and tremble before this mighty and terrific assembly of the free

${ }^{1}$ Gen. Wright in Ohio Arch. and Hist. Soc. Pub., vol. viii, p. I16.

${ }^{2}$ Plain Dealer, June gth,

${ }^{3}$ The Plain Dealer estimated the attendance at 25,000. The Crisis placed it at from 75,000 to 100,000 , stating that on the convention day alone 15,000 railroad tickets were sold and that only the smallest number came by rail. The crowds began to gather several days before the convention met. Large numbers came by wagon traveling in some cases over roo miles.

${ }^{4}$ Democratic governor of the state, I853-I855. 
men of Ohio, and recede from their despotic course as they did in Chicago the other day.

The temper of the delegates was bold, and their desires were unmistakable. Vallandigham and Olds were to be their candidates, and for a platform "Vallandigham was platform enough."

On an informal ballot, Jewett, whose name had been proposed, received only eleven votes, and with extravagant demonstrations of enthusiasm, Vallandigham was nominated by acclamation. As the one most closely associated with the candidate, Pugh was called upon to represent him in accepting the nomination. In a speech many times more violent than any of Vallandigham's utterances, he said that while he had not agreed with the nominee as to the possibility of deciding upon terms of peace by which the war might be settled, yet in order to decide the issue raised in any way at all, freedom of speech and debate must be allowed. He would not submit for one hour to the exercise of arbitrary, despotic, and irresponsible power. The Democracy had already submitted to more of it than any other people would have done, but there was a limit. $\mathrm{He}$ defied " Order Number 38."

I can die but once, and it matters little whether it be in battle or by a mock trial and sentence of a sham military commission-let the debt be gloriously paid in defense of liberty. I scorn your Order Number 38 . I spurn, I execrate, I trample under foot the order of any military officer defining treason and prescribing liberty. Come what will, come imprisonment, exile, stripes, hard labor, death, I defy Order Number 38 .

He called upon the members of the convention to act in case he was dragged before a military commission. If they did not act, he was determined to maintain his rights at the cost 
of his life. If the Democracy should fail in the election in October, he advised them to migrate to some other land where they might enjoy that liberty as citizens which they could no longer enjoy in their home country. In conclusion he entreated them in the name of the one hundred and eighty thousand Democrats of Ohio not to disperse until they had demanded of Lincoln the restoration of the person whom they had nominated for their candidate.

This inflammatory address stampeded the convention, and in spite of his protests and refusal, Pugh was nominated for lieutenant-governor to lead the campaign. Van Trump was placed on the ticket as the candidate for supreme judge, and the remaining offices were given to good Peace men.

After the ticket had been nominated, the matter of a platform gave the delegates little concern, and its construction was left to the party leaders. As adopted, it was rather conservative considering the candidates. The Democratic party was declared to be a law-abiding party, asking nothing but its rights under the Constitution and laws, and seeking to carry what it proposed, not by force, but by legal enactment. While obeying the Constitution itself, it had a right to demand that all others should do the same. Recognizing that every citizen owed allegiance to the government, "which consists of the civil and political institutions created by the Constitution," the right of criticising the administration which was "but the agent of the people," was distinctly averred. In accordance with that right, the resolutions protested against the Emancipation Proclamation; the scheme of compensated emancipation; and the proclamation of martial law in states where war was not existing. Neither Vallandigham's plan for securing peace, nor the plan proposed by the Peace Democrats of New York, was endorsed, but it was declared that the Democracy of Ohio "would hail with pleasure and de- 
light any manifestation of a desire on the part of the seceded States to return to their allegiance to the Government of the Union," and in such an event would "cordially and earnestly coöperate with them in the restoration of peace and the procurement of such proper guarantees as would give security to all their interests and rights." Whenever it should become practicable to obtain a convention of all or three-fourths of the states, such body should be convened to propose such amendments to the Constitution " as experience has proved to be necessary to maintain that instrument in the spirit and meaning intended by its founders." The guarantees of the Constitution violated by the arrest of Vallandigham were quoted at length. Considering the fact that at the time of his arrest he was a prominent candidate for the governorship, it was asserted "that the Democratic party was fully competent to decide whether he was a fit man for that nomination, and that the attempt to deprive them of that right . . . was an unmerited imputation on their intelligence and loyalty as well as a violation of the Constitution." The President was " respectfully but most earnestly" called upon to restore him to his home, and a committee of one from each congressional district of the state was created to apply for such action. Governor Seymour was thanked for his "noble letter," while the course of Governor Tod, in not only failing to protect the citizens of the state in the enjoyment of their constitutional rights, but actually participating in their violation, was "beheld with deep humiliation and regret." Finally, those who were representing the Democratic party as wanting in sympathy wtih the soldiers in the field were denounced as libelers and slanderers. "It is an outrage upon the Democratic party, that has always stood by the country, to assert that it is not the friend of its gallant defenders."

A real "state sovereignty" faction appeared in the con- 
vention headed by William $H$. Cory of Cincinnati, who presented a series of resolutions which had been adopted a few days before in the Madison county convention. They declared in favor of an immediate termination of the war and a separation of the sections, because the North had failed either by arms or by argument to sustain her right of conquest, and because the South was decided to separate from the Union at all hazards. An attempt was made to have these resolutions adopted as a substitute for the platform as reported, but the convention refused to receive them.

On June 26th, the committee selected by the convention to wait upon the President in regard to the release of Vallandigham, presented a formal request embodying the resolutions of the convention. A few days before this Lincoln, in replying to the resolutions of the Albany meeting, made perhaps the best argument possible under the circumstances. In substance this reply was as follows. Since the resolutions indicated that the meeting was in favor of suppressing the rebellion by military force, he would necessarily infer that those present would oppose anything which would tend to weaken that force. Many things not cognizable in the ordinary courts would do this. Vallandigham's arrest had been made because he was laboring to prevent the raising of troops, and to encourage deserters, thus weakening the army. The Constitution authorized the suspension of the writ of habeas corpus in cases of rebellion, whenever the public safety might require it. This, he contended, was done " on purpose that men may be arrested and held who cannot be proved to be guilty of defined crime," when the public safety required it. Such arrests were constitutional wherever the public safety required them. "The Constitution is not, in its application, in all respects the same, in cases of rebellion or invasion involving the public safety, as it is in time of profound peace and public security. 
The Constitution itself makes the distinction." In his own discretion he was not sure that he would have ordered Vallandigham's arrest. “It gave me pain when I learned that Mr. Vallandigham had been arrested-that is I was pained that there should have seemed to be a necessity for arresting him,- -and it will afford me great pleasure to discharge him as soon as I can, by any means, believe the public safety will not suffer by it."

In presenting their request, the Ohio committee took exception to several of these propositions. Sent by a convention " representing a majority of the citizens of the State of Ohio," they asked for the release of Vallandigham "as a right due to an American citizen, in whose personal injury the sovereignty and dignity of the people of Ohio, as a free State have been offended." To the President's statement that he would revoke the sentence so soon as he thought the public safety would not suffer by it, they retorted that from their own personal knowledge of the feelings of the people of Ohio, the public safety would be far more endangered by continuing Vallandigham in exile than by releasing him. They called attention to the fact that the charge against the prisoner did not impute to him either of the offenses mentioned by the President, and that the evidence at the trial did not support any such charge. If the views expressed did encourage someone to desert and that was a sufficient reason for his conviction, then every opponent of the Mexican war, the President included, might have been so convicted and banished. Exception was taken to the idea that the Constitution was any different in time of war from what it was in time of peace, and that the power of Congress to suspend the writ of habeas corpus carried with it the suspension of the constitutional guarantees of personal liberty. Finally, the committee protested against the idea that a person arrested for regularly defined treason should be en- 
titled to the constitutional safeguards, but when arrested without charge of crime, he should not be. The people of Ohio were willing to coöperate in every effort to restore the Union of the states, "but they cannot consent to abandon those fundamental principles of civil liberty which are essential to their existence as a free people."

In his reply the President decidedly weakened his side of the case by quibbling over the interpretation of his Albany letter. He was unable to perceive an insult to Ohio in the matter, and was wholly unaware at the time of the arrest that Vallandigham was a candidate for the Democratic nomination for governor. By the nomination of Vallandigham for governor when his views, expressed in and out of Congress, included the known assertion that an army was not the proper means for suppressing the rebellion, the Democratic party in Ohio assumed the attitude of encouraging desertions from the army and resistance to the draft. He did not think they desired that effect to follow their attitude, and hence to dispel that idea he submitted three propositions, on the endorsement of which by a majority of the committee, he would cause their names to be published and that should be in itself a revocation of the order in relation to Vallandigham. These propositions were: (I) that there was in progress a rebellion to destroy the national Union, and in their opinion an army and navy were constitutional means for suppressing it; (2) that no one of them would do anything which in his own judgment would tend to lessen the efficiency of the army and navy while engaged in the effort to suppress that rebellion; (3) that each of them would do all he could to have the soldiers and sailors, while engaged in the effort to suppress the rebellion, well provided for and supported.

In their rejoinder, the committee expressed surprise at the conditions suggested. Their opinions were well known, 
and they could not suppose the President expected that they would seek the discharge of their candidate, "by a pledge implying not only an imputation upon their own sincerity and fidelity as citizens of the United States, but also carrying with it by implication a concession of the legality of the arrest." The committee had no authority to enter into any bargain or pledge for Vallandigham's release; they had asked it as a right due to the people of Ohio. ${ }^{1}$

Much better would it have been, had Mr. Lincoln rescinded the sentence of the military commission and allowed Vallandigham to go free, especially since Burnside was rendered powerless to enforce his order in any subsequent case. The defiant speech of Pugh in the convention, and the open ridicule of the order by the other Democratic speakers, led to an earnest request to the President to have it either rescinded or enforced, since it was becoming a joke. ${ }^{2}$

In the meantime the exile traveled through the Confederate states and reached Wilmington, from which port he ran the blockade and succeeded in reaching Canada, establishing his headquarters at the Clifton House on the Canadian side of Niagara Falls. From this place on July

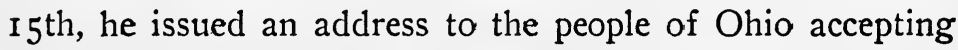
the nomination. He considered it

1 The entire correspondence between the President and the Albany and Ohio committees is given in McPherson, History of the Rebellion, pp. 163-I75.

'Ashley to Chase. Chase Papers, MS.

A stanza of one of the popular campaign songs of the year ran:

$\mathrm{O}$, brothers, dont forget the time

When Burnside was our fate,

And laws were superseded

By order 38 .

Then like a free-born western man,

Our Val spoke bold and true,

$O$, when he's chosen governor

What will poor Burnside do.

Wont he skedaddle,

As he's well used to do. 
an act of courage worthy of the heroic ages of the world; it was a spectacle and a rebuke to the usurping tyrants who, having broken up the Union, would now strike down the Constitution, subvert your present government, and establish a formal and proclaimed despotism in its stead.

He held the issue involved to be free speech, a free press, peaceable assemblages of the people and a free ballot. If "military necessity" be the pretext for all the acts and claims to arbitrary power, he warned his fellow citizens that their liberty was gone and tyranny was perpetual.

For if this civil war is to terminate only by the subjugation or submission of the South to force of arms, the infant of to-day will not live to see the end of it. . . . Traveling a thousand miles and more through nearly one-half of the Confederate States, and sojourning for a time at widely different points, I met not one man who was not resolved to perish rather than yield to the pressure of arms even in the utmost extremity. . . . Neither, let me add, did I meet anyone, whatever his opinions or his state, political or private, who did not declare his readiness, when the war shall have ceased and invading armies been withdrawn, to consider and discuss the question of reunion. ${ }^{1}$

At this distance, it is difficult to appreciate the intensity of feeling which prevailed throughout the campaign. During the months of July, August and September it was waged with a vigor and excitement that have never been equaled in the state. It was the high tide of Vallandigham's career, and but for the victories at Vicksburg and Gettysburg might have resulted in his election to the governorship. Both parties made a thorough canvass with the best talent at their command. ${ }^{2}$

${ }^{1}$ Crisis, July 22d.

2 Pugh, Thurman, Pendleton, Cox and Medary led the Democrats in 
Pugh made a strenuous campaign, speaking in every section of the state. He recounted the cost of the war in men and money and asked if there was not some better way. While Lincoln had been elected according to the forms of the Constitution, he was not to be obeyed when he overstepped its bounds. "And when he attempts to compel obedience beyond the limits of the Constitution by bayonets and by swords, I say that he is a base and despotic usurper, whom it is your duty to resist by every possible means and if necessary by force of arms." He held that there was no difference between the secessionists and Abolitionists except geographically; that the South had struck the first blow, but the Abolitionists had provoked it. ${ }^{1}$ Thurman took up the opposition to the war of 1812 , and the Mexican war, and asked if Senator Tom Corwin was a traitor when he said that if he were a Mexican, he would "welcome the American soldiers with bloody hands to hospitable graves." 2 All the Democratic speakers made a most powerful appeal for the election of their candidate because of the principle involved. Their counts against the administration were: the violation of the principles of constitutional liberty and the rights of an American citizen; the attempt to create a despotism by usurpation of power; and the miserable failure of the war, which had been changed from its original

the campaign with the assistance of Voorhees and Thomas H. Seymour. Neither Jewett, Ranney nor Payne took any part, the first declining even the single appointment made for him by the committee. The Plain Dealer did not print the ticket or make any mention of it editorially until the end of July. For the Unionists, Brough. Tod, Senators Wade and Sherman, the members of Congress from the various districts of the state, and all the other available talent was made use of. Many speakers were sent in from the other states to assist; the most important being Governors Morton of Indiana, and Yates of Illinois.

'See Marysville speech; Cincinnati Enquirer, August 21st.

'Cleveland speech; Crisis, July 8th. 
purpose to one of emancipation and confiscation. Vallandigham seriously contemplated coming into the state to take part in the canvass, but was persuaded not to do so by his friends on account of the danger involved. ${ }^{1} \mathrm{He}$ contented himself by writing a series of letters to the people of Ohio, and thus injecting his peace doctrines into the discussions.

In the face of these arguments, the Unionists began their campaign under considerable disadvantage and with much hesitation and doubt. Dwelling little on the conduct of the war and passing emancipation by as a settled fact, they made their appeal for support on the ground that the whole question of national existence was at stake and that the election of a "convicted traitor" would be a disgrace to the state.

Immense crowds attended the meetings of both parties.

1 Vallandigham, Life of Vallandigham, p. 349.

Senator. Sherman in his Recollections, vol. i, p. 324, says: "It was manifest that if Vallandigham entered the state he would be in great danger, and a quasi-civil war might have arisen. I heard men of character and influence say distinctly that if he came into the state he would be killed. . . Senator Wade and I met at Washington and had a conversation with Mr. Lincoln. We told him the condition of feeling in Ohio and of our confident belief that if his order of banishment was revoked, it would result in riots and violence."

${ }^{2}$ Murat Halstead of the Cincinnati Commercial wrote to Chase, August 24th, complaining in bitter terms about the administration of war affairs. He said that now since Burnside had left the city they would beat Vallandigham without the soldiers' vote if there could be a few minutes quiet on the negro question. "But it is worth while to say what here we all know that if the vote were taken in Ohio between Vallandigham and the radical policy of the President, the foolish and hopelessly impracticable proclamation, the election of Vallandigham would be the result. The essential thing is to keep the administration out of sight as much as possible, and talk of the cause of nationality and nothing else." Chase Papers, MS.

"The Crisis, August 5th, gave estimates of the numbers in attendance at some of the Democratic meetings as follows: "Such meetings as are now seen of the Democracy everywhere in this State have never before 
It was usually necessary to have speaking going on from several stands simultaneously, while addresses of three or four hours in length were not uncommon. Butternut and copperhead emblems were conspicuous at the Democratic meetings. Their parades always contained some allegorical representation of the thirty-four states, while their banners bore such inscriptions as, "Vallandigham and Liberty," "Peace and Union." One of the correspondents of the London Times wrote to his paper: "Vallandigham waits and watches over the border, pledged if elected governor of Ohio to array it against Lincoln and the war and go for peace." 1 This was much quoted in the press, and "waiting and watching over the border" became one of the popular expressions of the day.

In the midst of the campaign, a little band of about two hundred "War Democrats" held a convention, ${ }^{2}$ and declared themselves opposed to peace on other terms than unconditional submission to the Constitution and laws of the United States. They held that the nomination of Vallandigham was a great mistake and one which if approved and sanctioned by the people at the polls would seriously endanger the perpetuity of the government.

By the law enacted early in the year, the Ohio troops, for

been witnessed; were not even approached in the days of the political revolution of 1840 . At Bellefontain, on the 29 th, the crowd swelled to fifteen thousand. At Marysville ... some ten thousand were present; and on Friday, at Delaware, the concourse ranged from fifteen to twenty thousand, with thirteen hundred vehicles in procession, and regiments of voters on horseback. . . At Circleville, on Saturday, the meeting reached forty thousand." Of course allowance must be made for the exaggerations of a political campaign in these estimates.

'Letter of August 17th. The Times correspondent visited Vallandigham in Canada and wrote several letters strongly favorable to his interests.

${ }^{2}$ At Columbus, September $22 \mathrm{~d}$. 
the first time since the war began, would have a part in the election, and both parties made strong bids for their votes. However, since similar laws had been declared unconstitutional in some of the states during the year, ${ }^{1}$ there was some doubt about the validity of the measure, and it was realized that the election must be lost or won on the home vote. Some of the Democratic papers openly proclaimed that if their candidate had a majority otherwise, they would not consider the vote of the soldiers.

As the time for the election approached, the exertions of the contending parties were redoubled, and the tone of the speakers became correspondingly more violent. Pugh announced that if Vallandigham were elected, there would be fifty-thousand "stalwart able-bodied men, fully armed and equipped, freemen of Ohio, to receive their Governorelect at the Canadian line and escort him to the State House to see that he takes the oath of office," and Voorhees pledged the coopperation of the Democrats of Indiana. With this in mind, Brough asserted that the effect of the election of Vallandigham would be to precipitate civil war in the state.

For I tell you there is a mighty mass of men in the State whose nerves are strung up like steel, who will never permit this dishonor to be consummated in their native State. Another effect will be that it will be an invitation to the rebels in arms to come up and take possession of our soil.

The Union Leagues were active in distributing literature over the state, while the Democrats published "The Vallandigham Record" made up of the principal speeches of their candidate.

'In Connecticut, Pennsylvania and New Hampshire. The basis of the decisions was the constitutional requirement for voting at the place of residence. The Ohio law was later held constitutional. Lehman vs. McBride, 15 Ohio State Reports, p. 573. 



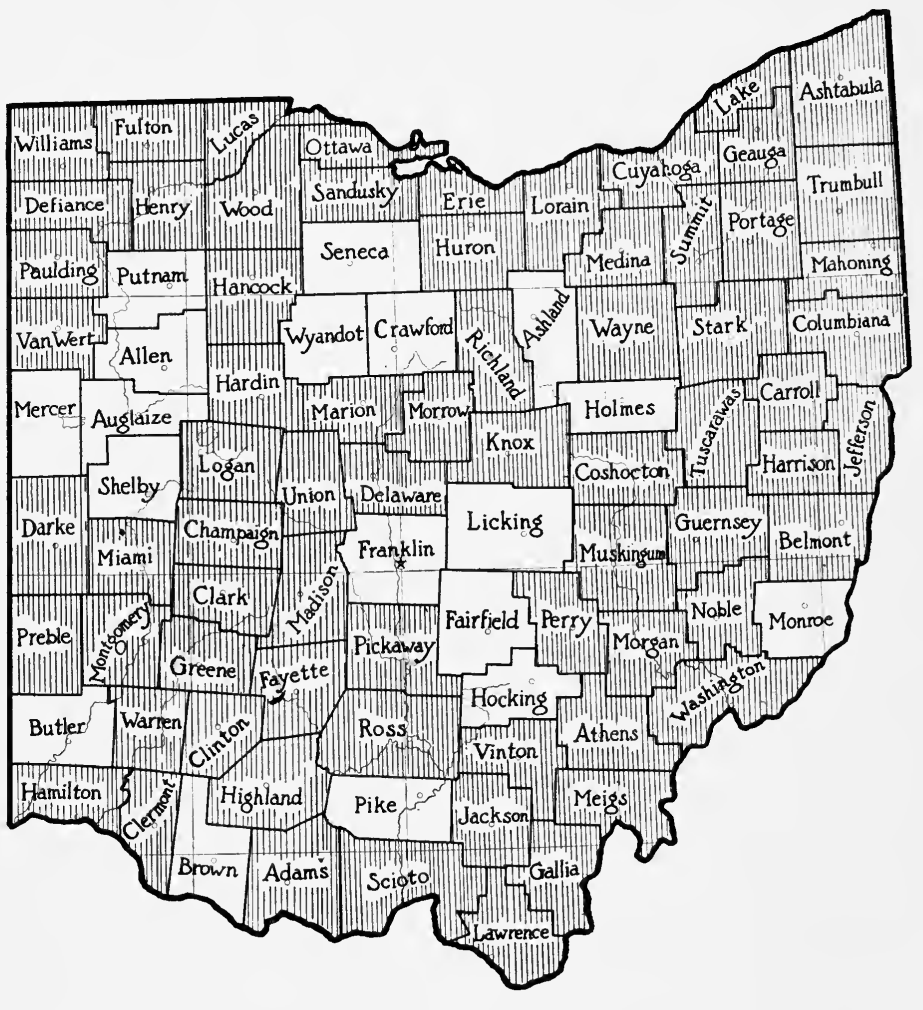

\section{ELECTION for GOVERNOR 1863}

Unionist Counties Shaded Democratic Counties Unshaded 
The people were left, therefore, at the close of the campaign with the prospect of a civil war as a result of their election. The Democrats were confident of victory, while Brough claimed a majority of at least five thousand on the home vote. ${ }^{1}$ The Unionists took every precaution to bring out the full strength of their vote. Chase was urged to see that the Ohio people in the 'Treasury Department were permitted to go home to vote, ${ }^{2}$ and he himself headed the delegation.

The result of the election was a surprise in many respects. The total vote was the largest ever cast in the state up to that time and over four thousand more than that cast in the Presidential election of the next year. Vallandigham received over three thousand more votes than the Democrats had polled the year before when they were successful. Yet Brough was elected by the overwhelming majority of IOI,000; of which 62,000 was on the home vote and 39,000 on the soldiers' vote. The vote of the soldiers was very light, only 44,000 ballots being received from the 160,000 troops in the field. ${ }^{3}$ The greatest Unionist gains were made naturally in the old Republican sections of the state. While the Democratic counties showed gains for both parties, those for the Unionists were much the greater,"

The effect of the victories at Gettysburg and Vicksburg; the almost superhuman efforts made by the Unionists to

${ }^{1}$ John Sherman, Recollections, vol. i, p. 327.

'W. D. Bickham to Chase, October 5th. Chase Papers, MS.

${ }^{3}$ The total vote cast in the elections during the three years I86r, 1862 and 1863 was as follows:

$\begin{array}{lccc}\text { Year. } & \text { Unionist. } & \text { Democratic. } & \text { Total. } \\ \text { I861 } & 206,997 & \text { I } 51,794 & 358,791 \\ 1862 & 178,755 & \text { I } 84,315 & 363,070 \\ 1863 & 288,374 & \text { I } 87,492 & 475,866\end{array}$

4 Vallandigham carried only 18 of the 88 counties. In the Congressional elections of 1862 , the Democrats carried 49 counties. 
secure every available vote; and the fear that the election of Vallandigham would precipitate civil war in the stateall had much to do in determining the result. It can hardly be interpreted as an endorsement of emancipation or arbitrary arrests, but rather as an evidence that the majority of the people of the state believed that a vigorous prosecution of the war was the only way by which peace and union could be restored. By this success of the Union party in Ohio, combined with similar victories in the other northern states, ${ }^{1}$ the Democracy was for the time being completely demoralized, and the administration was thus relieved of a dangerous opposition. ${ }^{2}$

The Democratic press of the state was not in accord as to the cause of their overwhelming defeat. The Crisis held that Brough's threat of civil war had deterred many from voting the Democratic ticket who otherwise would have done so. ${ }^{3}$ The Statesman accused the Unionists of gross frauds in importing illegal voters and in ballot-box stuffing, which amounted to the casting of about forty thousand illegal votes. ${ }^{4}$ It also held that the nomination of Vallandigham had been a great mistake, that not even one in five of those who had voted for him coincided with him in his peculiar views. The Enquirer, on the other hand, was inclined to think that his views represented the views of the

${ }^{1}$ The Unionists carried all the northern states except New Jersey, and also Maryland, Kentucky and Delaware. See Rhodes, History of the U. S., vol. iv, p. 416 .

"The N. Y. Tribune said, Oct. 3d: "Not only the people of the loyal but those of the disloyal States and of England feel that the fate of the Union rests upon the result of the election in Ohio."

Senator Sherman wrote in his Recollections; "I have always regarded Brough's election in Ohio as having an important influence in favor of the Union cause equal to that of any battle of the war." Vol. i, p. 328 .

October I4th.

October 2ist. 
Democrats of Ohio respecting the war, and that he would have been nominated even had he not been arrested or sent into exile. ${ }^{1}$

Vallandigham, though chagrined at the result, was not inclined to lose confidence in the ultimate success of his principles. He was certain that posterity would vindicate him, and "confident also that after some time be passed, I shall have justice and hold the power both. No man ever more than I, learned the lesson 'to labor and to wait.' ", While mourning over the calamities which he saw to be impending-the bloodshed and the enslavement of the people, he declared: "There never was a nobler contest waged for liberty and the right than by the Democracy of Ohio. All cannot be lost as long as such men, so many in number and animated by such a spirit, survive. In one way or another they will regain all." ${ }_{2}$ To his political brethren of the state he issued an address, October I4th, in which he said:

Your unconquerable firmness and courage, even in the midst of armed military force, secured you those first of freemen's rights-free speech and a free ballot. The conspiracy of the fifth of May fell before you. Be not discouraged; despair not of the Republic. Maintain your rights; stand firm to your position; never yield up your principles or your organization. ${ }^{3}$

With party feeling running so high throughout the year, it is surprising that so little violence occurred in the state. While there were many personal encounters and minor disturbances, usually between soldiers on furlough or from the camps of the state and Democrats, there were few instances where the trouble assumed proportions serious enough to call for the use of troops. In March, resistance was of-

1 October 3oth.

'Letter to his wife. Vallandigham, Life of Vallandigham, p. 334.

${ }^{3}$ Ibid., p. 334 . 
fered to the arrest of a deserter in Noble county, and it was necessary to send two companies of soldiers into the locality. No blood was shed, and after a few arrests were made, the trouble ceased. ${ }^{1}$ Again, in Dayton on the day following Vallandigham's arrest, a mob collected and the plant of the Dayton Journal, the Unionist paper of the city, was burned. General Burnside put the county under martial law for a few weeks, and sent a military force to preserve order. During the rest of the year excitement was intense at this place, and when, later in the summer, the Journal was revived, ${ }^{2}$ the paper was printed under the protection of two loaded cannon. Yet there was no further outbreak. The only other serious disturbance occurred in Holmes county in June where some prisoners arrested by the provost-martial for interfering with the enrollment were rescued by a small force of armed men. A force of about four hundred troops was ordered to the scene, and a proclamation was issued by Governor Tod calling upon those who were reported to be in arms to disperse. ${ }^{3}$ With the wounding of two of the insurgents and the arrest of a few more, the resistance ceased and the prisoners were given up. ${ }^{4}$ None of these affairs was directly connected with the political campaign, although they were declared by some of the Unionist speakers to be a result of the teachings of the Democracy. Ohio thus passed through the most exciting period of her career without the violence which was a feature of the times in many of the other northern states.

Another danger which threatened the state during the

'See Cincinnati Commercial, March 21st. Also Crisis, April 8th.

${ }^{2}$ W. D. Bickham of the Cincinnati Commercial staff became its editor.

${ }^{3}$ Executive Documents, I863, pt. i, p. 297.

4Gen. Cox, Reminiscences, vol. i, p. 470. Cf. also Official Records of the Rebellion, series i, vol. xxiii, pt. i, pp. 395-7. 
year was dispelled through the activity of the military authorities. The Knights of the Golden Circle, organized in the western states to oppose the war, were becoming active in Ohio. At the time the Democratic state convention was being held in Columbus, a large meeting of the members of this society was in session and open threats were made against the administration. Through spies and detectives it was discovered that there were over 80,000 members in Ohio, armed and drilled, and that a general uprising was planned for the i6th of August, when the rebel prisoners at Camp Chase were to be released and a union effected with some rebel commander who was to make a demonstration at some point along the southern border. ${ }^{1}$ Yet the uprising did not take place, and when, in the latter part of July, General Morgan made his raid through the southern part of the state, Governor Tod was able to call out the militia to oppose him in thirty-two counties without any disobedience to the call.

Vallandigham passed the winter and spring "waiting and watching over the border," ready to take advantage of any favorable opportunity to return to the state. Application was made to the United States Supreme Court by Pugh as his counsel for a writ of certiorari in order that the case might be brought up for review, but this was refused on the ground that the court had no authority to review the finding of a military commission. ${ }^{2}$ About the

'Report of Adjutant-General, Executive Documents, i864, pt. ii, p. 73.

${ }^{2}$ The decision was rendered in February, 1864. U.S. Supreme Court Reports, I Wallace, p. 385.

After the decision, Vallandigham wrote his brother: "The decision of the Supreme Court is as I expected it, and perhaps correct-a sad commentary upon the defects of our system and laws. After examining the question, I should have preferred that it should not have been carried to the Court, but Mr. Pugh was confident and insistent. Still it will matter not in the long run. Other remedies for this and other evils will alone avail now." $M S$. Letter. 
same time, Pendleton offered a resolution in the House of Representatives that the arrest and banishment "were acts of mere military power in palpable violation of the Constitution and laws of the United States," but this was rejected by a strict party vote. ${ }^{1}$

In the meantime the exile's friends were contributing to his support. In the issue of the Crisis of December I6th, I863, a letter was published suggesting that the ladies of Ohio contribute ten cents each as a donation for him. The idea was taken up by the press and a committee was appointed to receive the funds. As a result there was collected and forwarded to Vallandigham about twentythousand dollars, five thousand of which came from friends in New York. Some of the money was raised through fairs and socials held by the Democratic ladies for the purpose, but most came through individual contributions. ${ }^{2}$ The raising of this "Dime Fund" attracted considerable attention, and some notice was taken of it in the legislature. On January IIth, a resolution was adopted by the Senate instructing its judiciary committee to inquire and report by bill or otherwise, what legislation was necessary to prevent the payment of money to disloyal citizens. ${ }^{3}$ Some time later notice was given by one of the senators of his intention to introduce a bill to prevent disloyal practices, and to prevent citizens of the state from giving pecuniary aid to persons banished from the state for disloyalty. No action was

${ }^{1}$ Congressional Globe, 38th cong., Ist sess., p. 879.

'In February, Vallandigham wrote to his brother: "That 'Fund' promises to be munificent if not magnificent, and already amounts to $\$ 15,000$, and those concerned aim at much more. It will all be presented at once by a committee. . . . I watch and wait and am always ready, but of course my plans for the future are contingent upon events which I cannot control." MS. Letter.

"Senate Journal, 1864, p. 20. 
taken on the matter, however, and the contributions continued to be sent without interruption.

The injection of politics into religious sermons led some of the Peace Democrats, late in the year, to take up a new form of activity. Vallandigham had long denounced political preaching, and it had been referred to in many of the resolutions of the local conventions. ${ }^{1}$ At a meeting of the Methodist Church conference, held in Lancaster in November, resolutions were adopted pledging support to the administration and endorsing the war policy. Olds took exception to this action, and suggested through the Crisis ${ }^{2}$ that a state convention be held, "for the purpose of devising some plan for a new church organization in which Democrats may enjoy the privilege of having preached the pure gospel, ... unmixed with abolition and fanaticism, and without being insulted and denounced from the pulpit as disloyal." At a meeting held at Lancaster later, a formal call was issued for the convention. It met at Columbus on February $3 \mathrm{~d}$, and according to the reports of the Democratic press, was attended by delegates from seventeen counties. A society was organized under the name, "Christian Union," and the scriptures of the Old and New Testament were adopted as the "only and sufficient rule of faith and practice." As a result, congregations were established in various parts of the state, and services conducted according to the new doctrine of peace. After the close of the war, however, they were gradually abandoned, and the members were absorbed into the old denominations.

1 One of the most radical of these was adopted at a local convention in Butler county on March 14, 1863. It held, "that the clergy of the present day are the devil's select and inspired representatives, preaching hate, envy, malice, vengeance, blood and murder, instead of love, charity and the doctrines of Christ." Dayton Empire, March 16, 1863.

2 December 16 th. 
THE DEMOCRACY IN THE CAMPAIGN OF I864

The beginning of the year I 864 found the Democrats, as a result of their defeat, in a very much disorganized condition. There was, first, the little band of "War Democrats" who had declared against Vallandigham in the campaign, and who were preparing to meet on January 8th, to select delegates to a national convention, and make nominations for the state offices. Secondly, there was the extreme state-rights wing led by William M. Cory and Alexander Long ${ }^{1}$ of Cincinnati, which had attempted to impose its doctrines of peace and separation on the state convention in the preceding June. A third element consisted of Vallandigham's supporters, who stood on a platform of peace with union. Finally, there were those led by Ranney, Payne and Jewett, who favored a policy of suppressing the rebellion by force, but opposed the use of the method employed by the administration. The Crisis and Enquirer were strong for peace, the Statesman was rather neutral and labored to bring the various elements together, while the Plain Dealer advocated war measures and a war candidate for the Presidency.

On January 8th, two of these factions met at Columbus. The "War Democrats" held their convention, and reaffirmed their platform adopted in the previous September. Delegates were selected to attend a national convention which it was proposed to hold at Cincinnati in May, but it was deemed inexpedient to nominate a state ticket at that early date. At the same time, the Vallandigham men assembled at a Jackson Day banquet, and listened to addresses from Medary, Van Trump, Olds and Converse. While the tone of this meeting was much less radical than the one held a year before, yet there was no disposition shown to abandon the doctrines of peace.

'Democratic Congressman from the 2d District. 
During the early part of the year, many Democratis newspaper offices were mobbed by furloughed soldiers, the Mahoning Sentinel, Fremont Messenger, Ohio Eagle and Dayton Empire being the principal sufferers. A threat made against the Statesman was met with the answer that the property of the Abolitionists would be held responsible for any damage done. ${ }^{1}$ During the attack on the Dayton Empire office, an attempt of some of the Democrats to protect the property led to a conflict in which several persons were wounded. In commenting on this, the Crisis rejoiced to know " that the Democrats have at last learned that their only protection is in their own keeping." Vallandigham wrote from his retreat across the border expressing his regret that the editors were not prepared to "inflict on the spot, and in the midst of the assault, the complete punishment which the assailants deserved," and advised in the future, "instant, summary and ample reprisals upon the persons and property of the men at home, who by language and conduct are always exciting these outrages." 2 The Democrats were not, however, in a position to act in accordance with such advice.

As many of these riots had taken place before the adjournment of the legislature, they called forth an expression from that body in the form of resolutions which, while deploring the fact that certain public journals were publishing treasonable articles thus giving aid and comfort to the enemies of the country, condemned the acts of mob violence, and urged the people of the state to seek redress in the future through the legally constituted authorities. ${ }^{3}$ This adivice was followed by taking into custody the editors of

'Editorial, February 18, 1864.

${ }^{2}$ Letter to Editors. See Crisis, March 16th.

'March 31st. Lawes of Ohio, vol. 1xi, p. 200. 
some of the most objectionable newspapers. Medary was arrested in May on a warrant issued by the United States District Court at Cincinnati, under the act of Congress of July I7, I862, which provided a punishment for persons inciting rebellion or insurrection against the United States or giving aid and comfort to any existing rebellion or insurrection. ${ }^{1}$ He was taken to Cincinnati, but was released after being held for a few days.

The Democrats fixed on March 23d as the date for holding their state convention to nominate a state ticket and select delegates to the national convention at Chicago. As the time approached, the division between the peace and war factions became more sharply drawn. Butler, Montgomery, Franklin, Fairfield and Hardin counties pronounced squarely for peace, and endorsed Vallandigham for the Presidency, while in the northern part of the state most of the counties declared for McClellan, with Fremont as second choice.

In the organization of the convention, the war faction took advantage of their opponents. Olds was the candidate slated to preside over the session, but before the chairman of the central committee arrived at the meeting place, another member of the committee called the delegates to order, and a war man was chosen president. From that time on the convention was in the hands of the war faction. The platform was brief and artfully drawn so that it might be satisfactory to all the elements of the party. It declared the devotion of the Democratic party to the Constitution " as transmitted to us by the framers of that instrument, and expounded by Jefferson, Madison and Jackson, and as

1 McPherson, History of the Rebellion, p. 196.

Baker, one of the editors of the Statesman; John McElwee, editor of the Hamilton True Telegraph; Daniel Flanigan, editor of the Warren County Democrat, were others arrested and imprisoned during the year. 
construed in the Virginia and Kentucky resolutions of 1798 and I799," and pledged "life, fortune and sacred honor" for its maintenance. Any honorable effort toward a restoration of the "normal condition" of the Union would be hailed with delight. The party was held to be

opposed to the prosecution of the war for the subjugation of States or for the purpose of depriving them of their sovereignty or impairing their Constitutional rights ; and being satisfied that its continued prosecution for such objects will in the end prove the utter destruction of civil liberty, we therefore demand the immediate inauguration of peaceable means to attain an honorable settlement and the restoration of the Union under the Constitution.

The mob spirit abroad in the land was deemed the natural result of the violation of the Constitution and laws by the party in power.

Compared with the expressions of the party a year before, these sentiments were extremely mild. Vallandigham was not endorsed, nor was any request made for his return; his name was not even mentioned in the resolutions. Cory issued a broadside address advocating peaceable separation and a conclusion of the war on any terms, but he did not even get a place on the committee on resolutions.

No trouble was experienced in nominating a state ticket, but the factions crossed swords on the selection of delegates at large. The nominees included Pendleton, Allen, Thurman, Medary, Ranney and Vallandigham. On the first ballot, the first three of these were chosen. All the names were then withdrawn except those of Ranney and Vallandigham, and on the next ballot Ranney received a majority of four votes. The announcement of the result caused great confusion. A demand for the reading of the vote by counties was made by the peace men, but the chair- 
man ruled this out of order. An appeal was made, and the supporters of Vallandigham threatened to leave if they could not be heard. The demand was finally acceded to, but the result remained unchanged, and the choice was made unanimous. The division on the vote was for the most part geographical, the northern counties supporting Ranney and the southern ones Vallandigham.

The convention was thus decidedly in the hands of the war element. The Crisis and Enquirer were much disappointed with its work, the former holding that to their candidate as an individual, his defeat was not worth consideration, "but the public abandonment of personal liberty and crouching even by implication to the most odious of all tyrants is a misfortune no time can cure, nor can any apology excuse the mistake." 1 The Enquirer found much objection to the platform, considering that it was not very distinctly in favor of peace and not very distinctly opposed to it; that it was devised rather for party success than as the expression of the sentiment of the masses of the Democratic party. "For a party which six months ago in the State of Ohio polled 187,000 votes for a peace candidate, the largest vote of its history, it is several political centuries behind the times." 2 The Unionist papers found much enjoyment in commenting on the cunning with which the platform was constructed, dubbing it "a beautiful welding of peace and war."

Stirred by the defeat, Vallandigham prepared to return to the state to take up the fight in person. In February, at a meeting of the supreme council of the reorganized Knights of the Golden Circle, or "Order of Sons of Liberty" as the society was then called, he had been elected supreme commander. ${ }^{3}$ Great activity had been displayed

${ }^{1}$ Editorial, April 6th.

2 Editorial, March 26th.

' F. G. Stidger, Treason History of the Order of Sons of Liberty, p. 49. 
throughout the spring in organizing lodges in the counties of Illinois, Indiana and Ohio, so that by June the membership reached 200,000. ${ }^{1}$ Feeling safe with this number of supporters, under a heavy disguise and accompanied by a few of his closest friends, the exile entered the state, and appeared on June $15^{\text {th }}$ before the convention of the third district in session at Hamilton, to choose delegates to Chicago, just as the delegation from his county was deliberating as to whether or not it would be wise to put his name in nomination. ${ }^{2}$ To those assembled at the convention he said:

I am now here ready to answer before any civil court of competent jurisdiction, to a jury of my countrymen, and in the meantime to give bail in any sum which any judge or court, State or Federal, may affix; and you, the hundred and eightysix thousand Democrats of Ohio, I offer as my sureties. . . . I return of my own act and pleasure, because it is my Constitutional and legal right to return. . . . Endorsed by nearly two hundred thousand freemen of the Democratic party of my native State at the late election, and still with the sympathy and support of millions more, I do not mean any longer to be the only man of that party who is the victim of arbitrary power. ${ }^{3}$

' Vallandigham, Life of Vallandigham, p. 374.

'Ibid., p. 351 et seq.

' Vallandigham, Life of Vallandigham, p. 356.

The Enquirer and Crisis spoke very boldly regarding the protecting of Vallandigham should any attempt be made to molest him. While he was addressing the convention, a dispatch announcing his return was sent to the Illinois state convention, then in session. A reply was received stating that "Illinois will stand by Ohio in the maintenance of personal liberty." Cincinnati Enquiver, June 17th. The Union papers of the state were inclined to make light of his return, holding that it would be a serious embarrassment to the Democrats at Chicago. Lincoln, taking this view of the matter, allowed it to pass unnoticed. See Nicolay and Hay, Abraham Lincoln, vol. vii, p. 359. 
Under the enthusiasm aroused by his presence, he was selected by acclamation as one of the delegates. In other districts, the peace faction had secured the election of its most important leaders, and the Ohio delegation proceeded to Chicago in August, divided on the question of a candidate. Unable to prevent the nomination of McClellan, Vallandigham carried through, as a part of the platform, the well-known resolution

That after four years of failure to restore the Union by the experiment of war . . . justice, humanity, liberty and the public welfare demand that immediate efforts be made for a cessation of hostilities, with a view to an ultimate convention of the States, or other peaceable means, to the end that at the earliest practicable moment peace may be restored on the basis of the Federal Union of the States. ${ }^{1}$

In the campaign of this year the Peace Democrats, in Ohio as in the other northern states, made what was to be their last stand against the war policy. Most of the Democratic congressmen elected in 1862 were renominated, and the campaign was conducted on much the same issues as that of the previous year. Twice during the year, in May and September, a draft was ordered in the state; and in April, through the offer of the governors of some of the northern states to send their militia into service for one hundred days to do garrison duty, 36,000 of the national guard of Ohio were called into active duty. Both of these things were made into political capital during the campaign, especially the latter, and Governor Brough was denounced even by some of his own party for sending so many of the citizens out of the state at a time when they were busy with their summer's work.

While apologizing for the Presidential nomination of a

'Stanwood, History of the Presidency, p. 304. 
military man, the peace men, during the early part of the campaign, urged that he be supported because of the principles of the platform; but when McClellan sent his letter repudiating the peace resolution, Vallandigham cancelled his speaking engagements and withdrew from the field for a time, while his associates made sad efforts to reconcile it with the platform. Later in the campaign Vallandigham reappeared, and while opposing the candidate's views as being the very ones which had been voted down in the committee on resolutions at Chicago, yet, considering them as his own private views and the platform as the law, he declared he would still support him. ${ }^{1}$ The Crisis, however, refused to put his name at its mast head. ${ }^{2}$

The enthusiasm shown in the campaign of 1863 was lacking in the contest of this year. The military operations of the fall left little doubt of the approaching end of the war, while the issues of emancipation and arbitrary arrests no longer excited the feelings of the people of the state. The Union party carried the state in the October election by a majority of 54,000 , of which 28,000 were contributed by the soldiers. The vote was lighter by 56,000 than that of the preceding year, over 50,000 of which were at the expense of the Unionists.

On October I8th, under the direction of Long and Cory, a mass convention of the state-rights Democracy of Illinois, Indiana, Iowa, and Ohio was held at Cincinnati. In a speech in Congress early in the year, ${ }^{3}$ Long had expressed his belief that there was no possibility of restoring the Union and that it was necessary to acknowledge the independence of the South; these ideas he supported in terms

1 Speech at Sydney, Cincinnati Commercial, September 26th.

'See issue of September 28th.

'Cong. Globe, 38th cong., Ist sess., p. 1499. 
so strong as to lead to his censure by the House. ${ }^{2}$ At Chicago he had labored to have a plank included in the platform reaffirming the Virginia and Kentucky resolutions, but had failed. It was his object in this convention to supply the omissions of the Chicago platform in distinctly setting forth the time-honored doctrines of the party, and with this in view, resolutions were adopted declaring for peace and state rights and the Kentucky resolutions of I798. There was some talk of making an independent nomination, since McClellan had come out so openly for war, but owing to the lateness of the date this was given up.

In the November election, Lincoln received a majority of 60,000 in a total vote a little less than that of 1863 . About 25,000 votes were thus changed from the Unionists to the Democrats. These gains were pretty uniform throughout the state, and represented the strong war element of the Democracy which refused to vote for Vallandigham.

With the close of the war the great argument of the Peace Democracy was gone-the Union had been restored by war. Throughout the contest they had waged a persistent fight, and constituted a dangerous opposition. During the period of reconstruction, while the Union party was laboring to secure the results of the war, they were able to contend for the restoration of the Union as it was, and to raise an issue on the matter of extending the right of suffrage to the negro.

Much reproach has been cast on this opposition party of the war, and the terms "Butternut" and "Copperhead" still retain much of their early opprobrium. But something may be said in its justification. The Democracy of the West were not advocates of unqualified peace, but of peace with the old Union restored. They were not opposed to the

${ }^{2}$ See McPherson, History of the Rebellion, p. 387. 
government, but their quarrel was with the party which administered it. They held the Abolitionists responsible for provoking the war, and accused the administration of violating all constitutional safeguards in carrying it on. But forcible resistance was never advocated by the party to any measure, not even to the draft; and people were urged to remedy the evils through the ballot box.

In their platform of opposition, the Democrats could bring many counts against the administration. They were right, as the sequel proved, in their stand against arbitrary arrests, and their argument that the Constitution should be the same in war as in peace was a potent one. However, in contending that peace could be secured with the old Union intact, they failed to appreciate the fact that any compromise with the South on the basis of the old Constitution was impossible at any time during the war. Again, their arguments on the constitutional question were better fitted to a period when calm reasoning rather than inflamed passion was dominant. To the Unionists, the Constitution was not to be interpreted according to the letter, but by its spirit, and the arbitrary acts of the administration were justified on this ground.

An opposition party during a war period may perform a useful service in tempering the acts of the majority, and the Democrats, in many instances, performed this service during the Rebellion. The fact that there had been an opposition party during the war of 1812 and the Mexican war, was used by the party leaders to justify their course. But the two situations were different. The earlier war was waged against a foreign foe and the questions at issue were not vital, while in the rebellion the very life of the nation was in peril. In such a time, those who held that the Union could be preserved only by force, could look upon any who were opposed to them in no other light than as traitors. 


\section{CHAPTER IV}

\section{The Question of Negro Suffrage in Ohio}

\section{POLITICS OF THE YEAR I 865}

THE close of the war left both parties in the state apparently without an issue. Notwithstanding the continued reiteration of the Peace Democracy that the South could not be conquered, and that the Union could be restored only by peaceable means, the South had been conquered and the Union restored by force; though the destruction of slavery precluded the possibility of a return to the "Union as it was." On the other hand, the Union party had been formed on the sole platform of a vigorous prosecution of the war, and since the contest was ended, there seemed to be no further reason for existence. During the weeks immediately following the cessation of hostilities, there was talk of disbanding both parties. However, the desire of the one to secure the results of the war furnished a reason for continuance, while the other, with its training of the past four years, passed easily from the cry of executive usurpation, to that of congressional despotism.

Of the problems which grew out of the war, the one of most immediate concern to Ohio was the question of conferring political rights on the negro. The status of the colored race in the state was not changed politically during the war period. The "Visible Admixture law," passed in I857, had been declared unconstitutional in $1860 ;{ }^{1}$ and while the Unionists recognized the validity of this decision,

${ }^{1}$ Cf. supra, p. 23. 
the Democrats opposed it. As a result, in the sections of the state strongly Unionist, especially on the Reserve and in Greene county, mulattoes and, so it was asserted by the Democrats, even full-blooded negroes were permitted to vote at the elections. In some instances affidavits were made showing that this was carried on to a considerable extent. ${ }^{1}$

The question of eliminating the word "white" from the state Constitution was brought before the legislature during the sessions of $\mathrm{I} 860$ and I86I, by numerous petitions on the subject. In the House these were referred to the judiciary committee, which reported adversely, ${ }^{2}$ while, in the Senate, no action was taken. The Democrats tried to force the issue by offering resolutions proposing that an amendment defining the word "white" be submitted to the people of the state. Through a combination of the Democrats and some of the Republicans of the southern part of the state, one resolution came within three votes of receiving the necessary three-fifths majority. ${ }^{3}$

During the war, as has been noted, the Union party avoided the expression of an opinion on any phase of the negro question. While the amendment to abolish slavery was under discussion in Congress, attempts were made in the legislature to secure an endorsement of it, but none of the resolutions offered was allowed to come to a vote."

1 This was especially true in Greene county. After every election the Democrats charged frauds in this county. In a contested election case taken to the legislature from Hancock county, 1864 , the votes of mulattoes were held to be legal. Cf. House Journal, 1864, App., p. 3. In counties where there were only a few negroes, they were usually allowed to vote and their ballots marked so that in case of a close result they might be thrown out if necessary.

'House Journal, 1860, p. 183. $\quad 3$ Ibid., 1861, p. 374.

'Cf. House Journal, 1864, p. 293 ; 1865, p. 9. Senate Journal, 1865, p. 52. 
When Congress finally passed the joint resolution proposing the amendment, January 31, I865, Governor Brough transmitted a copy to the legislature with the following comment: "The people of Ohio will cordially and promptly respond to this important change in the organic law, and you as their representatives will, I doubt not, with equal cordiality and promptness, give legal power and expression to their voice in this particular." 1 The Senate took up the matter at once, and passed a joint resolution of ratification after a substitute ${ }^{2}$ had been offered from the Democratic side and defeated. After some attempts had been made to delay action, the resolution was adopted in the House by a strict party vote.

During this session of 1865 , a bill for the repeal of the "Visible Admixture law," which had passed the House during the preceding session, became a law. ${ }^{8}$ In the passage of an act for the relief of the poor, the legislature also wiped out the last of the "Black Laws," by repealing the statute which provided that no colored person should be held to have gained a residence in the state by virtue of having dwelt there for two years, and by making every person a legal resident of the township in which he had resided for a year and entitled to such relief as he might require. ${ }^{4}$ Thus at the close of the war, the Unionists began to make some progress toward a more liberal policy in regard to the negroes.

${ }^{1}$ Senate Journal, 1865, p. 101.

${ }^{2}$ This substitute provided that, "the maintenance inviolate of the rights of each State to order and control its own domestic institutions according to its judgment, is essential to that balance of power on which the perfection and endurance of our political fabric depends." It had been offered in the United States House of Representatives, January 18th, by Harding of Kentucky. McPherson, History of the Rebellion, p. 259 .

'Laws of Ohio, vol. lii, p. 42.

‘Ibid., p. 18. 
In Ohio, as in the other northern states, the politics of I 865 turned largely on the question of supporting President Johnson in his policy of reconstruction. In his proclamations issued on May 29th granting amnesty, with certain exceptions, to those who had participated in the rebellion, and prescribing a method of reconstruction for North Carolina, ${ }^{1}$ he announced, in effect, that he would continue the plan which Lincoln had begun. This was to put the control of political affairs back into the hands of those who had administered them before the war, provided an oath of allegiance prescribed in the proclamation was taken.

The Democratic press of the state, especially the Statesman, began to show, soon after Johnson's succession, that he was in accord with Democratic principles, and even to suggest that the two parties in the state unite in his support. Vallandigham came forward with a carefully prepared letter to point the way for the Democracy to follow. In the first place, he considered that the party must be continued with its fundamental principles unchanged, especially its true state-rights doctrine which was laid down in the Virginia and Kentucky resolutions as interpreted by their authors, the one by Madison in his report of 1799 and the other by Jefferson in his inaugural. But Vallandigham held it would be folly not to comprehend and recognize the radical change, in regard to men and policies, wrought by the war. It must be recognized that a new epoch had been reached. As to the past, he was willing to be judged by his record. If he had erred, it was in the glorious company of the patriot founders of the system of government; and while accepting the new order of things, he would still keep as near as possible to their teachings and practices. The new President differed from the Democracy as to the fact

${ }^{1}$ Richardson, Messages and Papers of the President, vol. vi, p. 312. 
and the manner of prosecuting the war, but if his policy on reconstruction should appear best, to secure a speedy and lasting pacification upon the basis of the Federal Union of the states, it would be best for the Democracy to lend him a hand. As to slavery, Vallandigham was willing to accept the issue and recognize that the institution was dead. The freedman, when admitted to reside in a state, ought, he declared, to be the equal of any other man in all legal rights and remedies, but political rights and social usages were questions which each state and community must be permitted to decide for itself. ${ }^{1}$

The Union party leaders began early in the year to arrange their program for the forthcoming campaign. On April 5 th, at a conference of the members of the state central committee and the Union members of the legislature and of Congress, June 2ist was fixed upon as the date for the state convention. A request from the Ohio soldiers in the field, for representation in the convention, was considered, and it was decided to allow each regiment, separately organized battalion and independent battery to send a delegate. The call was issued on April Ioth, and with it an address was published warning the people that the dangers were not yet passed and the objects for which the Union party had been formed were not yet attained. The great questions growing out of the war were urgently pressing upon the attention of the country. Men were needed in power both in state and nation, who would stand firmly by the guiding principles of the past four years.

Let it be fully understood that no man who has, in an official capacity whether civil or military, been connected with this unholy rebellion and thus imbrued his hands in the blood of his countrymen, can ever, with our consent, stand in the councils

${ }^{1}$ Ohio Statesman, June 3, 1865. 
of the nation, or assist in making laws for loyal men. . . . Let us all stand upon the broad platform of human freedom and the regeneration and elevation of every man born in the image of God.

This was the year for the election of a governor, and much difference of opinion developed on the question of a candidate. Brough had made himself unpopular with the Ohio officers in the army because of his strict rule of making promotions according to seniority rather than merit, while in the state there was considerable feeling against him because of his calling out the militia for the Hundred Days' service in the middle of the summer, when most people were busy with their farm work. There was also much personal opposition to him on account of a certain gruffness of manner. The old Republican element held that, since both Tod and Brough had been selected from the Democrats, it was proper that a candidate of Republican faith should be nominated, while the army expressed a decided preference for a military candidate. As the discussion progressed, the drift of sentiment seemed to be toward the choice of a man from the army, and the names of Generals Stedman, a former Democrat, Schenck and Cox were mentioned. Among those outside of the army, Galloway's name was most favorably considered. General Stedman declined to be a candidate, and the field narrowed down to Galloway and Cox.

On June I6th, Brough, in an open letter, declined to be a candidate for renomination and retired from the field. Two years previous he had undertaken the work, he said, only from a consideration of duty, with the determination that, if the military power of the rebellion should be broken and the war closed during his first term, under no circumstances would he be a candidate for reëlection. He had allowed that position to be modified to the extent that while 
he would not seek a renomination, yet if it should be conferred with a reasonable degree of unanimity he would not decline it. This, however, did not seem probable.

In times like the past four years, no man who has filled the position and honestly and conscientiously discharged the duties of the office of Governor of Ohio could hope to escape censure and opposition or fail to destroy what politicians call his availability as a candidate for reëlection. Such was the case with two of my predecessors who were earnest and good men. I could not and did not hope to avoid the same result. ${ }^{1}$

A few days later Galloway withdrew and Cox was left with a clear field.

In the local conventions the question of negro suffrage was uppermost. The Reserve counties adopted resolutions strongly endorsing it, while in the more conservative counties no expression was given. In the Montgomery county convention, Lieutenant-Governor Anderson ${ }^{2}$ offered a resolution, earnestly protesting against enfranchising the negro because, "having been so recently slaves we know that as a mass and upon the average they are not capable and worthy of this exalted function." The resolution was tabled, and another, giving it as the opinion of the meeting that it was both unnecessary and inexpedient that the state convention should take any action on the question, was disposed of by adjournment. ${ }^{3}$

In the Ohio state convention, one of the first to assemble after the change in the Presidency and the beginning of the disagreement between Johnson and the radicals, the delegates were left to formulate a platform without any

- Ohio State Journal, une 17 th.

'A brother of Major Robert Anderson, the hero of Fort Sumter. He was elected on the ticket with Brough in 1863 .

${ }^{3}$ Cincinnati Enquirer, June I6th. 
model. Senator Sherman was present to exercise a supervision over the work. The army delegates, one hundred and forty-three in number, headed by Colonel Charles $\mathrm{H}$. Grosvenor, were much in evidence, and were allowed representation on all of the committees. They were almost solidly opposed to negro suffrage and in favor of endorsing the President.

General Cox was nominated for governor by acclamation and Andrew G. McBurney, a Unionist of Democratic antecedents, who had served in the Senate during the war, was given the second place on the ticket. Of the seven offices to be filled, army men were nominated for three.

The resolutions were reported to the convention by Judge Dickson of Cincinnati, a Unionist of strong anti-slavery sentiments. They expressed thanks to God for the overthrow of the rebellion, and the preservation of the national integrity. Lincoln was eulogized, and Johnson's policy was endorsed as "looking to the restoration of peace and civil order in the so-called seceded States," and the " hearty and undivided support" of the Union men of Ohio was pledged to him. The party demanded that " reconstruction shall be at such time and upon such terms as will give unquestioned assurance of the peace and security, not only of the loyal people of the rebel States, but also of the peace and prosperity of the Federal Union." The proposed amendment to the Federal Constitution abolishing slavery was endorsed in a resolution which held that slavery and its institutions were "irreconcilably opposed to freedom and free institutions," and that the "bitter experience of the war pointed unerringly to their overthrow and eradication as our only safeguard against the recurrence of like evils in the future." The nearest approach to negro suffrage which the committee could make was expressed in the resolution, "that the experiencc of the last four years shows 
the absolute necessity in all our political actions of keeping steadily in view the great principles of our government as set forth in the Declaration of Independence."

After the platform had been presented to the convention, an attempt was made by Don Piatt to add a resolution committing the delegates to the doctrine, that the reconstruction of the southern states constitutionally belonged to Congress. A resolution was also proposed which had been adopted by the Grant reception meeting held in New York two weeks before, asking the coöperation of the Federal and state governments throughout the Union to use all possible means to establish a system of suffrage which should be equal and just to all loyal men, black as well as white. Neither of these proposals was allowed to come to a vote.

Owing to the variety of public opinion then existing in the state on the question of negro suffrage, the task of the committee on resolutions had been a difficult one. As first drafted by a subcommittee, the platform was silent on the matter, and a motion to include an expression in favor of it was voted down. Then under a threat of the Reserve members to bring in a minority report, Dickson suggested the compromise resolution, on keeping in view the principles of the Declaration of Independence, which was adopted, in order that " the integrity of the Union party might be preserved and the adoption of the constitutional amendment secured thereby." 1

To the radical element of the party, however, this compromise was very unsatisfactory. The Cleveland Leader voiced the general sentiment in that section of the state in saying that its objection to the platform was not to what was said, but what was omitted. "We looked for a bold

${ }^{1}$ Letter of Judge Dickson, Cincinnati Enquirer, August II, I865. See also letter of Judge Bishop, Cleveland Leader, June 23d, and speech of Hutchins at Warren, Cincinnati Commercial, August 16th. 
and explicit declaration from the Convention on the subject of negro suffrage in the South, and of equal suffrage to whites and blacks in the State of Ohio; we are disappointed that it has not so declared." 1 The most outspoken denunciation came from the Portage County Democrat, which accused the convention of having been under the sway of a timid conservative spirit. "The platform is a didactic emasculation unworthy of the Convention and unworthy of the stern demands of the hour. It enunciates no vital, living principle unless perchance the foggy reference to the Declaration of Independence may be regarded as such." ${ }_{2}$

By the middle of the summer, the breach between President Johnson and the radical leaders in Congress over the policy to be pursued in reconstructing the southern states, was assuming serious proportions. The radicals were becoming alarmed at the danger of restoring political control to those who had been actively engaged in rebellion, and were urging that the work of reconstruction should be taken out of the President's hands by Congress and entrusted to the freedmen and to the loyal element in the South. Senator Wade wrote, July 29th,

The President is pursuing and resolved to pursue a course in regard to reconstruction that can result in nothing but consigning the great Union or Republican party, bound hand and foot, to the tender mercies of the rebels we have so lately conquered in the field and their Copperhead allies of the North: ${ }^{8}$

As one of the leaders in the opposition to the President, Wade looked to Ohio for an endorsement of the radical program, and after the failure of the convention to speak out,

${ }^{1}$ Editorial, June 23, 1865.

${ }^{2}$ Editorial, June 26, 1865.

'Quoted in Rhodes, History of the U. S., vol. v, p. 533. 
his friends on the Reserve began an active campaign for negro suffrage not only in the South, but in the state as well.

Much was expected from the candidate for governor, by the friends of negro suffrage, because of his early Oberlin training. Shortly after the convention, he began to receive requests from both factions for a declaration of his views. Many letters from the soldiers in the field were published in the Democratic and conservative papers during July asking him for a statement of his position, but they remained unanswered. In sympathy with the President, it was his plan to avoid any expression of opinion until the opening of the campaign when matters would probably be more settled. ${ }^{1}$

However, under the pressure to which he was subjected for an expression of opinion, General Cox was driven to make a statement. In answer to a letter written from Oberlin July 24 th, by a committee of colored men, asking for his views in regard to negro suffrage both in the state and in the South, he prepared an elaborate reply. Protesting against any obligation as a candidate to answer questions which were not acted upon by the convention, and which

'On July 2oth, Cox wrote: "There is in the present condition of affairs but one thing which gives me serious concern and that is the apparent strength of the disposition manifested in some quarters to outrun the Administration and to separate from the President if he do not see it his duty to keep pace with the most radical of our people. I am thoroughly convinced that a breach with the President would be fatal to the organization of the Union party, and that it would be the surest means of defeating the very measures which are sought to be carried by such a course Under these circumstances I feel that our only hope of future usefulness as an organization is in teaching everywhere that unity among members is a primary duty, and in specifically and openly asserting that we will not make a nullity of our Convention resolution to support the policy of the Administration I shall keep very quiet till the campaign opens which will not be before the middle of August. Till that time I shall avoid all political speechmaking." $M S$. Letter to W. D. Bickham. 
were notoriously excluded from the list of those upon which a community of belief would be demanded, he proceeded, nevertheless, to give his opinion on the negro question. After four years of close and thoughtful observation, he said, he was unwillingly forced to the conviction that the effects of the war had been not simply to embitter the relations between the two races in the South, but to develop a rooted antagonism which would make their permanent fusion into one political community an absolute impossibility. He proposed as a solution of the problem, the peaceable separation of the races on the soil where they then existed.

The details of any system of separation could only be determined by careful study and a wide comparison of views. Suppose, however, that without breaking up the organization of any State, you take contiguous territory in South Carolina, Georgia, Alabama and Florida, and there, under the sovereignty of the United States and with only the facilities which the power and wealth of the Government can give, you organize the freedmen in a dependency of the Union, analogous to the western Territories. Give them schools, laws facilitating the acquirement of homesteads to be paid for by their own labor, full and exclusive political privileges, aided at the start, should it seem necessary, by wise selections from the largest brains and most philanthropic hearts among anti-slavery men to join them. ${ }^{1}$

He would make no coercive collection of the colored men in the designated region, but the majority being already there, he thought the reward of political power would draw the remainder rapidly.

Judge Dickson published a reply to this letter explaining the procedure in the committee on resolutions and declaring

'Cincinnati Enquirer, August 2d. 
that, from his own observation, he was satisfied that a large majority of the convention were of the opinion that negro suffrage would and ought to come, but that an expression on the subject had been waived in the interests of harmony. A man might be a member of the Union party in good standing, whether he was for or against negro suffrage. Considering the letter, therefore, merely as Cox's private opinion, Dickson denied the existence of any " rooted antagonism" and the whole philosophy founded upon it. He thought there was no antagonism which would necessitate the separation of the southern whites and blacks any more than the separation of the northern and southern whites. If the negro were given a' vote, he would be respected by the white man, but if it was the intention to make him a pariah, then a bloody war of races must sometime ensue. $^{1}$

In order to secure the opinion of an eminent economist on the subject, Dickson sent the Cox letter, with his own answer to it, to John Stuart Mill in England. Under date of September Ist, Mill replied that it would not be right to allow the states to be restored as they were and reduce the negro to practical slavery again; that some guarantee should be exacted. He regarded Cox's plan of colonization as chimerical, and suggested rather, that political control should be granted to "a mixed community in which the population who have been corrupted by vicious institutions will be neutralized by black citizens and white immigrants from the North." He was not averse to imposing an educational qualification on the negro provided it be required equally from the whites. ${ }^{2}$

The publication of Cox's letter precipitated a storm of

${ }^{1}$ Cincinnati Commercial, August inth.

${ }^{2}$ Ibid., September 20th. 
discussion between the radical and conservative papers of the state. The Portage County Democrat again reached the height of denunciation in its remarks. It called the letter "a verbose and turgic essay", and held that it would have been better " to have rejected either the nomination or the evasive platform, than to surrender manhood or apostatize from the principles and antecedents of former years." 1 The other Reserve papers, though disappointed in the letter, tried to make the best of it by declaring that it was merely a private opinion and could have no effect on the question at issue. The papers of the southern part of the state came to the rescue of the candidate, and denounced the Oberlin radicals, declaring that their program was sustained by less than one-tenth of the convention, and that Cox's views were those of the whole army, as well as those of the majority of the people of the state.

The Democracy remained quiet until the Union party had thus announced its program. On the day after the Union convention, the inner circle of the party met at Columbus for a conference. They not only failed to agree upon any platform of principles, but there was an actual break in the council, the state-sovereignty leaders withdrawing from its deliberations.

The nomination of General Cox inspired the opposing party to turn to an army candidate, and the name of General Sherman was suggested. It was received with approval, but the move was sudcienly checked by the General himself. In an address delivered at Columbus, July I $3^{\text {th, }}$ on the occasion of a celebration held in his honor, he announced that he had no political aspiration, but intended to hold his place in the army; he would not even accept the office of President. He expressed surprise that his friend

${ }^{1}$ Editorial, August 9th. 
Cox would exchange a major-generalship for the governorship, but was willing to support him in his candidacy. ${ }^{1}$

The state-sovereignty Democrats, failing to receive consideration for their views on nullification and secession at the Democratic conference, proceeded on their own account. Early in the year they had organized a state-sovereignty society at Cincinnati for the discussion of political questions, and had formed plans for securing control of the local convention in that city in March. ${ }^{2}$ Failing in this, they continued their activity and, during the summer, formed associations in Highland and Madison counties. ${ }^{3}$ Finally, on August I 7 th a state convention was held and a full ticket, headed by Alexander Long, nominated on a platform embodying the doctrines of state nullification. With the idea that it would weaken the party, the Unionist papers encouraged the movement, while the Democratic press ridiculed the affair, the Plain Dealer dubbing it "a little tea party of sore heads".

The regular convention of the Democracy was not held until August 24th, an unusually late date. Vallandigham, as temporary chairman, thanked the party for his nomination two years before, and announced that the immediate duty of the convention was to reaffirm the ancient and timehonored principles of the party and to announce a policy with reference to the new issues of the day, especially those of the Union of the states and negro suffrage and equality.

The platform adopted was an extremely long one. As opposed to the principles of the state-sovereignty faction, the true doctrine of the party was declared to be, not nullification and secession, but the doctrine of state rights as

${ }^{1}$ Ohio State Journal, July 14, 1865.

${ }^{2}$ See letter of Cory to William Cornell Jewett; Ohio State Journal, March I3, I865.

${ }^{3}$ Cincinnati Commercial, July 21st. Ohio State Journal, August 5th. 
announced in the Virginia and Kentucky resolutions and interpreted by their authors. The ordinances of secession being void, the so-called seceded states were still in the Union as states, and therefore entitled to all the reserved rights of the states. The effort to confer the right of suffrage upon the negro was held to be "an insidious attempt to overthrow popular institutions, by bringing the right to vote into disgrace", and it was declared " that this Government was made by white men, and so far as we have the power to preserve it, it shall continue to be a government of white men." Finally, in regard to the policy of the President, it was resolved: "That while we will resolutely and persistently condemn all infractions of the Constitution by whomsoever committed ... we will nevertheless stand by President Johnson in ail Constitutional efforts to restore immediately to the States the exercise of their rights and powers under the Constitution."

The ticket nominated was headed by General George W. Morgan, who had represented the United States as minister to Portugal during Buchanan's administration and, during the first three years of the war, had served as a brigadiergeneral. In his speech before the convention, he held that the southern states should be received again as friends, both sides confessing that they had profited by the terrible lesson of the four years of war. He was opposed to General Cox's plan of segregating the negroes, because Congress had no authority under the Constitution to convert one or more states into a negro dependency. The land would have to be acquired by purchase or by the extermination of the whites. The pirrchase, he considered, would be impossible since it would involve an expenditure of the enormous sum of about $\$ 600,000,000$. His solution was for the negroes to remain where they were, protected in life and liberty, without suffrage rights. $\mathrm{He}$ was opposed to 
enfranchising the negro in Ohio or in the South, at any time or under any circumstances. ${ }^{1}$

In consequence of this diversity of opinion on the negro question, the campaign of the year was rather complicated. Since this was the year for the selection of a new legislature, the radical Unionists were interested in securing the election of members who would favor the submission to the people of an amendment to strike the word "white" from the state Constitution. In all the local conventions on the Reserve, resolutions were adopted calling for this change and repudiating Cox's plan. But outside of this section of the state, the Unionists were inclined to stand by the convention resolution endorsing the President's policy of reconstruction. The Democrats were disturbed somewhat by the bolting of the Long and Cory faction and its nomination of a separate state ticket and of separate local tickets in a few of the counties. ${ }^{2}$

The Unionists opened their campaign at Warren, the home of General Cox, on August I5th. The speakers were Cox, Tod, Garfield and Hutchins, the successor of Giddings in Congress, and their addresses emphasized the wide divergence of views in the party. Cox held that the defeated rebels of the South were looking to the Copperhead element of the Democracy as their natural ally in the political struggle which was taking the place of the military conflict, and that the Union party must therefore be kept together to do what the Union army began. He discussed the two solutions of the negro suffrage question, separation and amalgamation, and defended the plan announced in his Oberlin letter. Garfield and Hutchins spoke against Cox's plan, and declared themselves in favor of giving the fran-

1 Ohio Statesman, August 25th.

${ }^{2}$ Highland, Madison and Hamilton. 
chise to the negro both in the South and in the state. Tod was opposed to changing the state Constitution, because he did not want to do an injustice to the colored men by inviting them into the state when they were better off in the South, and he had gone to Washington, he said, to urge on the President that the blacks in the South should not be permitted to vote.

During the course of a speech at Oberlin, August 2Ist, Cox was asked if he would favor a negro suffrage amendment to the state Constitution if elected. He had not answered this question in his letter to the Oberlin committee, and had avoided it in his earlier speeches of the campaign. His reply was that he believed the question must be settled for the colored race as a unit, and that the duty of the negro in the state was to connect his destiny with that of his brethren in the South. However, if the matter had to be determined by each state for itself and the South for itself, he would favor the application of the full rights of man in Ohio. ${ }^{1}$

General Morgan did not open his campaign until the middle of September. In his opening speech, he made much of the probable effect on labor in Ohio of conferring suffrage on the negroes and thus extending an invitation to the colored people of the South to come into the state. $\mathrm{He}$ read from Henry Ward Beecher's sermons on "Miscegenation" and "Universal Suffrage", both of which he declared were being used by the Unionists as campaign documents. He repeated the attack made in his convention speech on Cox's plan on the ground of the vast expense it would involve. The question of reconstructing the southern states was handled by Vallandigham, who argued for a full restoration of their rights, and urged that the past be

${ }^{1}$ Cincinnati Commercial, August 22d. 
forgotten and only present issues be considered. He was forced, however, by the attacks of his opponents to take up a defense of his record during the war.

The Democrats worked on the feeling against negro suffrage with all their power and strategy. A few days before the election was held, an address was issued by the state executive committee calling attention to the

monstrous scheme of the radicals to place negroes upon a footing of perfect political and social equality with the whites and to govern the country in all time to come by means of negro votes. . . . to the frauds, peculations and defalcations of abolition officials, almost daily brought to light, and the contrast between the ambiguous and deceptive platform of the abolition State Convention, and the unequivocal, outspoken principles announced by our Convention. ${ }^{1}$

Advances were made to the soldiers, who were as a rule opposed to granting the franchise to the colored people either in the state or in the South, and in local conventions they were given prominent places on the tickets. The Democratic state ticket was called the "Soldiers and Sailors' ticket" and the "White man's ticket." The question of taxing the bonds of the United States was also injected into the campaign.

There was no progress made by the Unionists toward uniting on the suffrage question as the campaign advanced, though they realized that it must have an important effect on the election. ${ }^{2}$ Governor Brough, on account of illness,

${ }^{1}$ Crisis, October 4 th.

${ }^{2}$ Flamen Ball, U. S. District Attorney, wrote to Chase, August 22d: "Politics run wild in Ohio. Cox, your old friend, seems to have fallen into the arms of the Conservatives and to have ignored all the former teachings of Oberlin . . His course, unfortunate as it is, will not I think defeat his election, but it must greatly reduce the Union majority and thus give an impulse to the Copperhead faction." Chase Papers, $M S$. 
was not able to take a part in the contest. He dissented, however, from the views of Cox, and predicted that Cox would live to see the day when he would regret having expressed them. He had faith that the President would succeed in reaching the right policy toward the South, and urged that the people support him. ${ }^{1} \quad$ But the Reserve was determined to stand or fall on the question of conferring political rights on the negro.

The vote in the election, as compared with that of 1863 . was light, almost 60,000 fewer ballots being cast. . While Morgan's vote was 6,000 greater than that of Vallandigham had been, the Union vote showed a decrease of about $65,000-$ one-third of which came from the Reserve. Cox received a majority of 30,000 over his opponent, while the average majority of the other Union candidates was about 31,500. Long received only 360 votes. The legislature as elected stood: House, 70 Unionists and 35 Democrats; Senate, 25 Unionists and 12 Democrats.

Under the circumstances, the election settled nothing as to negro suffrage, and the contest was transferred to the new legislature. On the first day of the session in January, I866, a resolution was offered in the Senate, by one of the Reserve members, providing that an amendment eliminating the word "white" from the state Constitution should be submitted to the voters at the next October election. ${ }^{2}$ The discussion, begun during the campaign, was taken up throughout the state with increased animation. Governor Anderson, in his annual message, ${ }^{3}$ took a decided stand against the project, as he had done during the campaign.

'Letter of W. H. Smith to Chase. September 7, i865. Chase Papers, MS.

${ }^{2}$ Senate Journal, 1865, p. 8.

${ }^{3}$ Executive Documents, I865, pt. i, p. 201. Anderson had succeeded to the office on the death of Brough in the preceding year. 
Many of the conservatives expressed their willingness to let the amendment go to the people so that it might be voted down and thus settle the matter. The colored people of the state organized an "equal rights league", and in addition to besieging the legislature with petitions, met in convention at the state capital to present their claims in person. During the progress of the discussion, it was pointed out by the press that the resolution could not be submitted until the election of $1867,{ }^{1}$ and on this account its consideration was postponed until the next session, by which time the radicals hoped popular sentiment would be more favorable to its passage.

The question of choosing a United States Senator came up in the midst of the discussion on the negro. There was considerable opposition among the radicals to returning Sherman, because of his record on several of the war measures. He had voted against the endorsement of Lincoln's suspension of the writ of habeas corpus. He had supported the plan to limit emancipation only to the slaves of those in rebellion, and had proposed so to amend the bill for raising colored soldiers as to entitle masters to pay for the services of their slaves. Finally, he had voted against the repeal of the Fugitive Slave law in 1863. General Schenck was a candidate against Sherman, but, notwithstanding the opposition, on January $\mathrm{I} /$ th Sherman was nominated in caucus on the second ballot, and later duly reëlected.

ATTITUDE OF OHIO TOWARD THE QUARREL BETWEEN PRESIDENT JOHNSON AND CONGRESS

During the session of Congress which began on December 4 , I 865, the quarrel between President Johnson and the

${ }^{1}$ The Constitution says, article xvi, section $i$, that amendments may be voted on only at an election held for choosing senators and representatives. 
radicals over reconstruction became acute. The Freedmen's Bureau bill, passed by Congress on February 6th, was vetoed on the I9th. On March I3th the Civil Rights bill was sent to the President, and on the 27 th met a like fate. The passage of this last bill over the President's veto on April 9th " rendered the breach between him and Congress complete." 1 There was also under discussion a bill to extend the suffrage to the negro in the District of Columbia, and an amendment to the Constitution, which, as finally passed on June $\mathrm{I} 3^{\text {th }}$ and ratified by the states, became the Fourteenth Amendment. All of these matters came into prominence in the state legislature, and by the close of the session, April 6, I866, the line was sharply drawn in Ohio between the Johnson men and the supporters of the radical policy of Congress.

In accordance with the sentiment expressed in the platform of the party in $186_{5}$, the Johnson men attempted to get an endorsement of his policy from the legislature. Two resolutions with this in view were offered in the Senate during January. ${ }^{2}$ One of these was tabled and the other referred to the committee on Federal relations, which reported a compromise substitute, approving Johnson's policy, but also expressing confidence in the faithfulness and wisdom of Congress in the exercise of its powers in the work of reconstruction. ${ }^{3}$ No action was taken on the report. In the House a similar resolution was tabled, and later a vote to take it up for discussion was supported by all the Democrats present, twenty-nine, and by twelve Unionists, while forty-three Unionists opposed it. ${ }^{4}$ At a Union caucus held on February 2oth, to consider the veto of the Freedmen's

' Rhodes, History of the U. S., vol. v, p. 586.

'Senate Journal, pp. 37 and 54.

3 Ibid., p. 99.

'House Journal, p. I5I. 
Bureau bill, a resolution was adopted applauding the action of the Union members of Congress from Ohio, in their support of the measure. A Democratic caucus held on the same day resolved to support the President. ${ }^{1}$ A few days later in the House, a resolution was proposed stating that the action of the Union caucus did not properly represent the views of the General Assembly, but this was tabled. When the news of the veto of the Civil Rights bill came, one of the Democratic members of the House proposed a vote of thanks to the President for his act. The session ended, however, without any official expression of opinion by the legislature either for or against the President's policy, although it was known that he was very solicitious in regard to the views of the people of Ohio, as reflected by her legislature. ${ }^{2}$

Outside of the legislature the division into opponents and supporters of Johnson was rapidly being made. Johnson ratification meetings were held by the Democracy to endorse the President's action on the congressional measures, and the Democratic members of the Assembly issued an address to the people of the state asserting that the Abolitionists were engaged in schemes to destroy the southern states and hold them in vassalage. ${ }^{3}$

Governor Cox was active in trying to reconcile the differences between the two factions. Two days after Johnson made his indiscreet speech of February $22 \mathrm{~d},{ }^{4}$ Cox went to Washington and had an interview with him in which Johnson elaborated his views on reconstruction. His whole

'Ohio State Journal, February 21st, and Statesman of same date.

${ }^{2}$ The Washington correspondent of the Cincinnati Commercial wrote to his paper that the President would be much encouraged by an endorsement of his policy by the Ohio legislature.

${ }^{3}$ Cincinnati Enquirer, March 7 th.

'McPherson, History of Reconstruction, p. 58. 
heart, he said, was with the true men who had carried the country through the war, but opposed to the obstructionist policy of the extremists who would bring ruin on the nation. Cox wrote these views down, and after having them verified by the President, sent them in a letter to the chairman of the Union state central committee with this postscript:

Such, my dear sir, is the statement of the President on this important matter, and if you could meet his straightforward honest look and hear the hearty tones of his voice as I did, I am well assured you could believe with me that, although he may not receive personal assault with the forbearance Mr. Lincoln used to show, there is no need to fear that Andrew Johnson is not sincere in his adhesion to the principles upon which he was elected. ${ }^{1}$

This generous endorsement was destined to cause the governor some embarrassment later on.

With the idea of taking full advantage of the break in the Unionist ranks, the Democrats fixed on an early date, May 24 th, for the holding of their state convention. In the call the great issue before the country was declared to be whether all the powers of government should be concentrated in the hands of the general government and a consolidated despotism be thereby established, or whether the rights of local self-government should be preserved. An invitation was extended to all who were opposed to the schemes of the conspirators, who cherished the institution founded by the fathers, or who were opposed to negro suffrage, "to join with the Democracy in rescuing the country from the malignants." There was much in the situation to give the Democrats hopes of success in the campaign of the year,

${ }^{1}$ Cincinnati Commercial, February 27th. Also Rhodes, History of the U. S., vol. v, p. 578. 
if the proper steps were taken. Vallandigham wrote to Thurman a few days before the convention: "We have the game in our own hands; let us play it boldly and strongly." :

A conference of the leaders was held just before the convention met, in which it was agreed that a short, concise platform should be adopted; the assumption was that the issue in the campaign would be the restoration of the southern states. ${ }^{2}$

The convention brought together many of the hitherto scattered and lukewarm members of the party from all sections of the state, many of whom had not been active in its councils since the early years of the war. The keynote was opposition to congressional despotism and support of the President. The platform followed the decision of the leaders, and consisted of three brief resolutions which had been adopted a few days previous in the Montgomery county convention, where Vallandigham was chairman of the committee on resolutions. ${ }^{3}$ It declared the one great question of the day to be: "The immediate and unconditional restoration of all the States to the exercise of their rights within the Federal Union under the Constitution." The President was pledged cordial and active support " in all necessary and proper means to carry out his policy as directed to that that end, and especially in securing immediate representation in the Senate and House of Representatives to the eleven States from which it is now unconstitutionally and arbitrarily held."

Thurman, Vallandigham and Pendleton addressed the delegates on the issue before the country. Vallandigham became rather violent in his denunciation of Congress, and

${ }^{1} M S$. Letter in the Governor Allen Papers.

${ }^{2}$ Cincinnati Commercial, May 24th.

3 Ibid, May 26th. 
said of the proposition then on foot to depose Johnson: "If they should attempt his deposition, the President would be right in bringing to bear against them the whole power of the army and navy of the United States." In contrasting conditions existing at that time with those of the preceding administration, he said: "But a little while ago we came to conventions with our lives in the hollow of our hands. Heavily armed the Democracy came here. To-day they came unarmed and in peace. A new administration has been inaugurated at Washington." 1

This was a well-planned and well-executed stroke to secure the support of the Johnson element of the Union party. To counteract it, necessitated unusual efforts on the part of the Unionist leaders, in devising some platform which could hold both factions of the party together. In the call for the Union convention, therefore, an appeal for harmony was made on the broad ground of patriotism. Though the war was over, the same political issues were held to be still before the country, together with new and important questions involving the credit of the government at home and abroad. The party was urged to "ignore false issues and all appeals to passion and prejudice" and " meet in council resolved to stand by the principles which have guided us during the first years of trial."

In the local conventions, the question of supporting the President came up, but in most of them no action was taken. In a few counties the congressional policy was endorsed. In Butler county resolutions were adopted demanding that loyal citizens be protected and traitors punished, in order that the country might know that rebellion and treason were criminal and ought to be made odious. Lewis D. Campbell offered others endorsing the President's policy

${ }^{1}$ Ohio Statesman, May 25th. 
and opposing the extension of the suffrage in Ohio to negroes. After much discussion, the convention adjourned without taking any action on these resolutions. As a result, under the leadership of Campbell, a second convention was held and they were adopte:1 as a platform. ${ }^{1}$

When the state convention met, June 2oth, the efforts to secure harmonious action were made manifest in all of its proceedings. The temporary chairman, ${ }^{2}$ reverting to the fact that the party had preserved its unity for the past five years, urged that all differences be adjusted so that the fruits of the war might not be lost. The problem of constructing a platform was simplified somewhat by the fact that the Reserve was willing that negro suffrage should be laid aside until the next year, and by the passage of the resolution by Congress just a week before proposing the Fourteenth Amendment. In presenting the resolutions, the chairman of the committee said that they had been framed with the purpose of avoiding technical difficulties and of embodying the principles of the loyal people of the state. They demanded that peace should be established "upon such stable foundations that rebellion and secession will never again endanger our national existence," endorsed the proposed Amendment " as a liberal, wise and patriotic adjustment," and pledged to it the united and hearty support of the Union party of Ohio.

While the idea of harmony was uppermost, the convention was dominated by the supporters of Congress, and all of the nominees on the ticket were of that faction. The Cincinnati Commercial, speaking for the conservative element, thought the platform "was carefully studied, judicious, simple and comprehensive," and a fair compromise

${ }^{1}$ Cincinnati Commercial, June IIth.

'Judge Hoadley of Cincinnati. 
between the original proposition of the radicals and the program of the President. ${ }^{1}$

Yet the endorsement of the congressional policy, mild as it was, gave little comfort to the Johnson men, and when the call came from the "National Union Club" for a national convention ${ }^{2}$ of those " who, in a spirit of patriotism and love for the Union, can rise above personal and sectional consideration, and who desire to see a truly National convention which shall represent all the States and Territories of the Union," they vigorously took up the work of organizing the state for this new party movement. A call for a mass convention to meet August 7 th was issued, signed by about a hundred names representing sixteen counties. All Union men were invited to come who believed the union of the states to be indissoluble, who desired that loyal representatives should be admitted to their seats in Congress, who held that to each state belonged the regulation of its own elective franchise and who were unwilling to declare the war for the Union a practical failure by making its restoration contingent upon political issues, independent of obedience to the Constitution and of submission to the laws.

Those who were most active in this movement in the state were of course men who were holding Federal offices under appointment from Johnson. With them were associated many of the Unionists of Democratic antecedents, such as General Stedman and William S. Groesbeck, who refused to follow the Union party into the ranks of the radicals, and many of the old Whigs, such as Lewis D. Campbell and Thomas Ewing. A great effort was made, apparently on the suggestion of President Johnson, to se-

' Editorial, June 22d.

${ }^{2}$ Dunning, Reconstruction, p. 7.3. 
cure the coöperation of Governor Tod, but the advances made to him met with no response. ${ }^{1}$

The Democratic members of Congress approved the call for the national convention, and accepted the invitation extended to the Democracy to participate. By the plan adopted, each state was to be allowed eight delegates at large and four from each congressional district, to be divided equally between the Democrats and the Johnson men. However, owing to the shrewd move which the Democrats of Ohio had made in their convention, to bring the Johnson men under their standard, there was much opposition shown, especially by Vallandigham, to thus sacrificing the party. While refusing to have anything to do with Vallandigham, Johnson made overtures to the more conservative members of the party to secure their support. A meeting of the state central committee was called for July i2th to take action on the matter, and it was then resolved that, since the movement was likely to result in the organization of a third party, no delegates should be sent, but the identity of the party preserved. $^{2}$ On the next day, for some reason, this action was reconsidered, and the executive committee was authorized to appoint the delegates at large and to issue an address to the Democrats of the several congressional districts, recommending the appointment of the district delegates by the several county central committees or by district conventions.

These instructions were carried out, and the address when issued stated that had not the state committee "been fully satisfied that the proposed Convention has not for its object a disbanding of the Democratic party and merging it in a

'Letters of J. H. Geiger, August 2d, and R. P. L. Baber, September 28th, to Johnson. Johnson Papers, MS.

${ }^{2}$ Letters of Gen. G. W. Morgan to Johnson, July 7th, I3th and 14th. Johnson Papers MS. 
new organization," the members would not for a moment have sanctioned it." As delegates at large, Ex-Senator Allen, Pendleton, General Morgan and M. R. Willett were selected.

Vallandigham was left off the list apparently by design, but was made a delegate by his district. Stung by the slight which he rightly attributed to the influence of the Johnson men, he wrote an open letter to the state central committee, in which he said that he had accepted the appointment of delegate only on the assurance that it was not the intention of the convention to propose any measure looking to the disbanding of the Democratic party. He attributed the jealousy, shown toward the movement by the great mass of the Democracy, to the fact that its managers were among the chief supporters of Lincoln and his party, and thus responsible for the wrongs of the past five years. Therefore all who would accept the situation and, even yet, avert the natural fruits of civil war, must forget the past and make the great issue of the hour the sole test of present fellowship and coöperation. Of the plan to exclude him, he said :

I am not unaware that a handful of mischievous and evil disposed persons of the Republican party now among the professed friends of the President, but themselves of peculiarly odious and unpatriotic record and antecedents, pretend to set up tests for admission to the Philadelphia Convention as against certain men, in fact all men of the Democratic party. The combined indecency, presumption and folly of this pretense, together with the mingled treachery and hypocrisy of the motives which prompt it, render it too contemptible for further notice. ${ }^{1}$

He thought that if the convention was to apply any other test than the attitude of the delegates upon the one great

${ }^{1}$ Cincinnati Commercial, August 2d. 
issue of the day as set forth in the call, it had far better not assemble at all. Considerable annoyance was caused by this tirade, and steps were at once taken to keep the author quiet at Philadelphia. ${ }^{1}$

About two hundred delegates assembled on August $7^{\text {th }}$ in convention under the leadership of L. D. Campbell, just appointed minister to Mexico; M. P. Gaddis of Cincinnati, assessor of the second district; L. A. Harris and J. M. Connell, collectors of the first and twelfth districts respectively; and J. H. Geiger, a former Chase man, who had become dissatisfied because he had not received a sufficiently remunerative office. The platform approved the principles set forth in the call for the national convention, and, to allay the fears of the Democrats, opposed any union with any existing party as a party, but hoped to unite at the polls with all men who were in favor of the principles and objects of the call. A letter written by Thomas Ewing, Sr., to O. H. Browning ${ }^{2}$ under date of August $2 \mathrm{~d}$ was read before the convention, and its sentiments endorsed. In it the writer argued that one part of Congress could not keep the other part out, that the exclusion of states as states for any reason was a violation of their constitutional privilege. and that laws passed by such a part of Congress were of doubtful constitutionality and might be thrown out by the courts. $^{3} \quad$ As delegates at large, Ewing, Campbell, Stedman

${ }^{1} \mathrm{~J}$. H. Geiger, writing to Johnson August 2nd on the prospects for the coming state convention, said: "We shall have an active energetic body of men whose souls are in the work. We are hurt more by the prominence given Vallandigham than by all other causes. Our people shrink from contact with him, he must be kept down at the Philadelphia Convention or we shall be badly crippled in Ohio. The fellow's doctrines now are not so bad, but his name is damnation." Johnson Papers, MS.

${ }^{2}$ Shortly before, appointed Secretary of the Interior by Johnson.

${ }^{3}$ Ohio Statesman, August 8th. 
and Groesbeck were chosen, and a full set of district delegates was selected. A resolution was adopted instructing the central committee to meet later to consider the propriety of nominating a state ticket for the National Union party.

Ohio was therefore represented at Philadelphia, August I 4th, by a full quota of delegates divided equally between the Democrats and the Johnson Unionists. The opposition to Vallandigham and to Fernando Wood, who had been sent as a delegate from New York, was carried to the floor of the convention. Not only was there a feeling that the presence of these men as delegates would prevent the cooperation of many necessary voters, but Vallandigham was particularly offensive to the Union delegation from Ohio because of his war record and his recent letter. Wood withdrew without making any protest, but Vallandigham would consent to give up his seat only after having a resolution read to the convention which had been adopted by the Ohio Democratic delegation asserting their readiness to stand by him, and while endorsing his motives and fitness, consenting to his withdrawal for the sake of harmony. ${ }^{1}$

In the convention of southern loyalists and northern supporters of Congress, held at Philadelphia, September 3 d, to offset the Johnson convention, ${ }^{2}$ Ohio was represented by a full quota of four delegates from each congressional district and eight delegates at large, both chosen by the Union state central committee, the latter including Wade, Dennison and Stanley Matthews.

In addition to these activities, the state-sovereignty men, notwithstanding their poor showing in the election of 1865 , held a state convention at Cincinnati, July 5 th, and nomi-

'Vallandigham, Life of Vallandigham, p. 4II. Crisis, August 22d. Also Rhodes, History of the U. S., vol. v, p. 6r4.

${ }^{2}$ Rhodes, History of the U. S., vol. v, p. 621. 
nated a state ticket. Their platform declared against merging the Democracy and Johnsonism, and demanded the immediate trial of Jefferson Davis on the merits of the question whether or not a sovereign state had the right to secede. An organ of the party, the West and South, was established at Cincinnati.

During the period in which these various conventions were being held, congressional and local conventions were also called. In all the districts which they normally controlled the Unionists nominated supporters of Congress. In all the districts except two, the Democrats nominated members of their own party. In the Dayton district, General Durbin Ward, a Unionist of Democratic antecedents, was run as an independent candidate against General Schenck, and was supported by the Democrats, while in the Scioto county district, a Johnson candidate received their support. In the local conventions the tendency was for the Johnson men and the Democrats to fuse on a ticket.

The fight in the campaign was made on the congressional elections and the issue was Johnsonism against the Civil Rights and Freedmen's Bureau Acts and the Fourteenth Amendment. Governor Cox, in his opening speech, made a strong plea for harmony. The real question in the canvass was, he considered, whether the Union party after directing the policy of the government through the war to a glorious result should destroy itself. In every political organization, there must be compromise and difference of opinion on matters of detail. He could see no fundamental question upon which there was any disagreement, since all the members of the party agreed that some terms should be imposed on the southern states. There was an apparent disagreement on the sort of terms to be imposed, but, he maintained, the terms proposed by the President were identical with those for which the Union party had declared in 
its convention. The only real difference was the manner of imposing the terms; Congress would do it by an amendment to the Constitution, the President would do it otherwise. This being only a minor matter, there was no reason why all the elements of the party could not unite. ${ }^{1}$ This speech was much above the average campaign address, as were those of all the speakers throughout the campaign.

To aid the Union cause, a delegation of twenty-eight southern delegates, on their way from the Philadelphia convention to visit the tomb of Lincoln, stopped for four days and made addresses in different parts of the state. General Butler made a tour through several counties, speaking on impartial suffrage. In most instances the Johnson men and Democrats held their meetings together. The President on his trip "swinging round the circle," visited Cleveland, where his experiences were very unfortunate, and also stopped at Cincinnati on his return east. Shortly before the election, the Democratic executive committee issued an address declaring that the real question at issue was whether less than one-third of the people should despotically govern more than two-thirds, and reciting what it considered would be the results of radical success at the polls-civil war, the disfranchisement of white men and the confiscation of their property as well as other dire calamities. ${ }^{2}$ The campaign in Ohio as in the other northern states was quite spirited and the appeal was made rather to the intellect than to the emotions.

At the election the Union state ticket was carried by a majority of 43,000 . The cnly gain made by the Democrats was one congressional district, General Morgan being elected over Delano with a change of about five hundred votes in the district. The result as a whole was a rather

${ }^{1}$ Cincinnati Commercial, August 22d.

${ }^{2}$ Crisis, October $3 \mathrm{~d}$. 
painful surprise to the Democrats, after their high hopes of the early part of the year. The Crisis considered that it was due to the folly of the party in abandoning the original plan of campaign and saddling itself with all the faults of the administration. This policy gained no appreciable number of votes from the conservatives, and disgusted many Democrats. $^{1}$ The Statesman had no comment to make, while the Plain Dealer thought the result came from the holding together of the ranks of the Union party by the argument that Johnson was a traitor.

The radicals were unable to place any interpretation on the result so far as the question of negro suffrage was concerned. The chairman of the state executive committee, writing to Chase on this subject, said:

It is very difficult, as you well know, in Ohio, with her great variety of people, to tell with any degree of certainty what a majority of them want or to arrive at the general average of their political conditions. In Ashtabula our party is almost as different from that part of it in Fairfield as the whole party is from the Democracy, and upon our radical views the two counties are very wide apart. . . . In the radical counties our majorities are steadily increasing, while our conservative counties are as weak as they were ten years ago, simply from the fact that in the latter the difference between the two parties is so slight that there is but little choice for earnest men between them. In the Reserve counties some of our speakers have openly advocated impartial suffrage, while in other places it was thought necessary not only to repudiate it, but to oppose it. . . My own opinion is that we made a mistake in not declaring for impartial suffrage a year ago. Now I fear it is too late to do so and carry the elections in 1868 , for we must suffer losses and probably defeats for one or two years by such a course. ${ }^{2}$

'Crisis, October 26th.

"MS. Letter of October 12, 1866 . Chase Papers. 
The election over, the alliance between the Johnson men and the Democrats was dissolved. However, many of the Democrats who joined the Union organization in I86I returned to their original party affiliations through this movement, and thus placed themselves in opposition to the more extreme policies of the Unionists the next year.

\section{NEGRO SUFFRAGE DEFEATED}

The year I867 saw the question of negro suffrage brought to a direct issue in Ohio politics. The Fourteenth Amendment, designed to make the negro a citizen and to cut down the representation in Congress of those states which deprived him of the franchise, was before the state for ratification, and the proposition to amend the state Constitution, which the Union party had dodged in the preceding year, could no longer be postponed.

When the General Assembly met for its adjourned session on January $2 \mathrm{~d}$, these matters were facing it. The Constitutional Amendment was promptly ratified by a joint resolution which passed the Senate on the second day by a strict party vote, and was carried in the House on the next day with eighteen Unionists from the conservative counties absent. ${ }^{1}$ A few days later the House adopted a resolution thanking Congress for passing over the President's veto the bill giving the franchise to the negroes in the District of Columbia, ${ }^{2}$ but the Senate tabled it. When Congress passed its first reconstruction act, March 2 d, dividing the southern states into military districts and prescribing negro suffrage as a condition precedent to their being restored to their normal relations with the Union, a resolution of endorsement was proposed in the House. It was kept in suspense until the last day of the session, when it was tabled.

${ }^{1}$ Laws of Ohio, vol. lxiv, p. 320.

' House Journal, i867, p. 39. 
On the question of amending the state Constitution, the contest raged throughout the session. Frequent caucuses of the Unionists were held in an attempt to get the members of the party together on the matter, but with little success. On January $I 7$ th a resolution was offered in the House by one of the conservative members proposing an amendment bestowing the suffrage on every male citizen of the United States resident in the state who had never engaged in rebellion against the government and who could read the state Constitution and write his own name. ${ }^{1}$ Some days later another proposition which had been offered by the conservatives in the first session, was revived. It was designed to enfranchise all citizens except "such persons as have been engaged in arms against the United States or who have left their place of residence to avoid being drafted into the military service of the United States." 2 Both of these propositions were tabled, but when on February 26th, a resolution to strike the word "white" from the Constitution, which had been postponed from the preceding session, came up for discussion, they were offered as amendments. The Democrats and radicals combined to defeat them, and on the adoption of the resolution itself the vote stood thirty-nine to fifty. The members from the Reserve together with those from the counties bordering it on the south and from Lucas, Union and Gallia voted in the affirmative, while the Democrats and conservative Unionists voted solidly in the negative. ${ }^{3}$ These votes showed the attitude of the various factions at the time: The radical Unionists were for a straight suffrage amendment; the conservative Unionists were ready to vote for negro suffrage, provided they could. at the same time, disfranchise as many Peace Democrats as possible; the Democrats were flatly against any change.

${ }^{1}$ House Journal, 1867, p. $59 . \quad$ ' $T$ bid., p. 132.

${ }^{3}$ Ibid., p. 273. 
During the discussion and the balloting there was much excitement in the Hall of Representatives. The governor and most of the higher state officers were present, while the galleries were filled with friends of the amendment. Various reasons were given in the debate for the adverse votes. Some members held that they had been elected two years before, when the question was not an issue, and hence were not in a position to support it; others came from constituencies which were directly opposed to it. Some were afraid lest a vote in favor of the enactment might mean the defeat of their county ticket. Many sought to relieve the situation by having the matter postponed, until the regular time for revising the Constitution. ${ }^{1}$ There was much disappointment felt by the radical element at this action of the House, and much criticism was heaped upon those members who had voted approval of the act of Congress by which universal suffrage was granted in the District of Columbia, and yet had not dared to vote for a resolution which simply gave the people the right to say whether or not they favored the proposition in the stale. However. an attempt to reconsider the vote failed.

On the next day, February $27^{\text {th }}$, the Senate took up a resolution providing for universal suffrage which it had postponed during the previous session, and, after a month of debate, passed it by the necessary three-fifths vote. ${ }^{2}$ In the House twenty-six Unionists still held out, and their support could be gained only by adding an amendment to the Senate resolution disfranchising those who had

borne arms in support of any insurrection or rebellion against the Government of the United States, or have fled from their places of residence to avoid being drafted into the military ser-

1 187 . Article xvi, section 3, of the Constitution.

'March 27th. Senate Journal, 1867, p. 4II. 
vice thereof, or have deserted the military service of said Government in time of war and have not subsequently been honorably discharged from the same.

The Senate struck out the clause disfranchising deserters, but the House refused to agree. In order to fulfill the constitutional requirement of having a proposed amendment published for six months before the election at which it was to be voted on, it was necessary to come to some agreement before April 8th, and after a committee of conference had failed to adjust the differences, the Senate receded from its position and allowed the House amendment to pass.

The House sought, by disfranchising as many of the Peace Democrats as possible, to gain popularity for the measure in doubtful counties and especially in the southern part of the state. It was soon realized, however, that the deserters clause would have a serious effect on the Union party. It was found that there was a total of 27,178 deserters credited to Ohio, about one-fourth of whom had deserted after Lee's surrender, fearing that they might be sent to the Mexican border or the Indian frontier to serve out the remainder of their three-years enlistment. In order to remove the ban from these, the House adopted a resolution soliciting the good offices of the Ohio Senators and Representatives in Congress to have a law passed requiring the secretary of war to issue honorable discharges to all who had left after April I5, I865, but the Senate refused to assist in freeing the House from the dilemma.

The spring elections came just before the legislature passed the resolution, and the Democratic press made negro suffrage the issue. The result was a reduction of the Union majorities in many places, and this was interpreted as a repudiation of the proposition.

The Democrats had already held their state convention 
on January 8th, Jackson day, this date being fixed upon as a fitting time to restore the party to its original principles. The conservative element was in disfavor because of their carrying the organization into Johnsonism, and the proceedings were entirely dominated by Thurman, Vallandigham and Pendleton. This triumvirate proceeded to make a division of the political spoils among themselves. Thurman was to have the nomination for governor; Pendleton, the endorsement of the party for the Presidential nomination in I868; while Vallandigham, in case the legislative elections could be carried in the fall, was to be sent to the Senate to succeed Wade.

With this agreement in mind, these leaders took charge of the convention. Pendleton presided over the sessions, and Vallandigham was chairman of the committee on resolutions. No military men were prominent; the prevailing atmosphere was much like that of the convention of 1863 . The platform reaffirmed the old doctrines of limited powers and strict construction of the Constitution. The reconstruction measures then before Congress, were held to be " unconstitutional, revolutionary, and despotic." Negro suffrage, it was declared, would be productive of evil, and would "tend to produce a disastrous conflict of races." Cory attempted to add the first Kentucky resolution of I799 containing the idea of state veto; his plan was to stimulate the authorities of Kentucky, where the Democrats were in power, to call a convention to nullify the reconstruction legislation. According to the program, Thurman was nominated for governor, with the duty of releasing the state "from the thraldom of niggerism."

After the suffrage amendment had been passed by the legislature, the Democratic central committee, taking advantage of the blunder which had been made, issued an address calling for the support 
of every man who is opposed to the establishment of an equality of the white and black races in the State, and to the disfranchisement of those soldiers who did faithful service throughout the actual continuance of the war, but who returned home before receiving an official discharge. ${ }^{1}$

The state-sovereignty Democracy proceeded on its own account to agitate the remedy of state veto. At a meeting held on February I Ith, resolutions were adopted calling on the people of Kentucky to provide at once for a convention with authority to veto any law of Congress which violated the Federal Constitution by giving ballots or bayonets to negroes within her limits. A committee was appointed to memorialize the Kentucky legislature on the matter. The formation of state-sovereignty societies, in every congressional district of the variou. states, was urged, " to educate our deplorably ignorant political leaders in the true knowledge of our sacred and most glorious institutions, now so outrageously abused everywhere, and menaced with total overthrow." A national convention attended by delegates from Ohio, Kentucky, Indiana, Illinois, Iowa and Alabama was held at Cincinnati on April I $3^{\text {th. }}{ }^{2}$

During the early part of the year, the Unionists were much at sea on the question of a suitable candidate, who could stand squarely on a negro suffrage platform and, at the same time, command the support of the conservative element. Cox, realizing that he could not measure up to the standard, declined to be a candidate for renomination. ${ }^{3}$ The Cleveland Leader, while regretting the loss of so good a governor, was willing to sacrifice him because he was not

' Cincinnati Commercial, April 22d.

${ }^{2}$ The proceedings were all published in the West and South. See also the Crisis, May ist.

${ }^{3}$ Letter to state central committee, Cleveland Leader, Jan. 26th. 
in accord with the party on the great issue of the day and had been indiscreet enough in his Oberlin letter and in his eulogy of Johnson to make that want of harmony prominent. ${ }^{1}$ Later on, it was suggested that he reconsider his decision, and for some weeks his record on negro suffrage formed the subject of serious discussion in the press.

Other names suggested were those of Schenck, Garfield, Dennison, General Keifer, who had the support of the G. A. R.; B. R. Cowan, chairman of the state central committee; General Hayes, and Galloway. By the time set for holding the convention, June I 19 th, sentiment was crystalized around Hayes as the most available candidate. He had a good war record, and at this time was representing the second district in Congress. No objections were offered to him by any faction of the party, except that the Wool Growers' Association complained of his attitude in Congress toward the tariff on wool. ${ }^{2}$

Regarding a platform, the radical element stood uncompromisingly on the two propositions: equal suffrage in the South as provided by the reconstruction acts; and negro suffrage in Ohio as proposed by the constitutional amendment. ${ }^{3}$ Governor Tod was solicited for an opinion. In response to resolutions of the Union convention of Cuya1. a county approving the acts of his administration, he k the opportunity "to express the hope that the Union $y$, formed in $\mathrm{I} 86 \mathrm{I}$, to suppress the rebellion, will not lisband. Its work is not yet finished ... the poor made free by the rebellion must be protected and cared the Government. . . . The Union party is in honor to see to this." He was ready to approve the recon-

rial, January 27 th. omplaint was made through the Plainsville Telegraph. ial, Cleveland Leader, June Irth. 
struction measures of Congress as providing "all that is required to secure to the African race prosperity and happiness," and to endorse the action of the legislature on the matter of negro suffrage in the state. ${ }^{1}$

When the convention met, an attempt was made by the Chase men to bring the Presidential question into the proceedings, by urging the nomination of Schenck, as an endorsement of Chase against Hayes, who was a Grant man. ${ }^{2}$ The plan failed, however, and on the first ballot Hayes received two hundred and eighty-six votes as against two hundred and eight for Galloway and a few scattering votes for the other candidates.

The platform endorsed the reconstruction measures of Congress and placed the party " on the simple and broad platform of impartial manhood suffrage, as embodied in the proposed amendment to the state Constitution, appealing to and confiding in the intelligence, justice and patriotism of the people of Ohio to approve it at the ballot box." No mention was made of the deserters clause, which by this time was causing the party much embarrassment. After a heated discussion in the committee, it was decided simply to endorse the suffrage part of the amendment.

There seemed to be almost unanimous approval of the work of the convention among the radical element. Even the Portage County Democrat was enthusiastic over both the candidate and the platform. ${ }^{3}$ The Wool Growers' Association held a meeting in Cleveland, July 4 th, and decided to take no action on the election for governor, but to use all its energy in the election of a state legislature which would send a sound tariff man to the United States Sen-

${ }^{1}$ Cleveland Leader, June 25th. The letter was written June 18th.

2 "Mack" in the Cincinnati Commercial, June 2Ist.

${ }^{3}$ Editorial, June 26th. 
ate. The only expression of disapproval came from Galloway, who was much disappointed over his failure to secure the nomination for governor. He was given second place on the ticket, but declined it in an open letter in which he attributed his defeat to the fact that he would enter into no intrigues with Presidential aspirants. ${ }^{1}$

The heavy weight of the deserters clause was partially removed by an act dubbed by the press "The Ohio Deserters Bill", which was hurried through Congress, July I 7 th, by Ashley of the Toledo district. It provided that no soldier or sailor should be considered a deserter who left his command after April 19, I865, without authority. It was not. however, to act as a remission of forfeiture of pay, bounty or pension, but solely as a removal of any disability such a soldier or sailor might have incurred by the loss of his citizenship in consequence of his desertion. ${ }^{2}$

In the local conventions the suffrage question caused some serious contests, and in many of the southern counties no endorsement was given to the amendment. The Brown county convention resolved that the matter should not be made a party question, but left for Union men to vote upon as they might choose, without prejudicing their standing in the party. The burden of supporting the proposition was to be left with the radicals.

Both parties opened their campaign on August 5th, and for two months carried on a contest which for enthusiasm $31 . j$ intensity compared very favorably with that of 1863 . -al Hayes in his opening speech dwelt on the efforts Union party to preserve nationality, in contrast to the ination of the Democracy to destroy it. At the openthe war, he said, the creed of the Union party had

itatesman, July $4^{\text {th. }}$

Statutes at Large, vol. xv, p. I4. 
been simply, "the restoration of the Union." Gradually the party had realized that slavery and rebellion were convertible terms, and that liberty and union were inseparable. The Peace Democracy, at first overwhelmed by the popular uprising which followed Sumter, was able, after its success in $\mathrm{r} 862$, to mark out a path of opposition to the war measures, to Lincoln's administration, and in particular to every measure tending to the enfranchisement and elevation of the African race. On reconstruction, Hayes argued, the parties differed in the same way. The Democracy opposed the placing of any condition upon the restoration of the southern states, while the Union party held the military reconstruction measures and the Constitutional Amendment to be the only means of accomplishing what all people most desired, the reëstablishment of constitutional government in the South. The assertion that the government was a white man's government he denied. "It is not the Government of any class or sect or nationality or race. . . It is not the Government of the native born or of the foreign born, of the rich man or of the poor man, of the white man or of the colored man-it is the Government of the freeman." The "monstrous inconsistency and injustice of excluding oneseventh of our population from all participation in a Government founded on the consent of the governed " was held to be impossible. There was no necessary antagonism between the two races which could not be broken down by justice and equality. ${ }^{1}$

Thurman, in his opening speech, made a powerful attack on the policy of the Union party in changing the country from a constitutional government to a despotism in which the Constitution was set at naught. "Indeed," he said, " it is but truth to assert that there is scarcely a provision oi the

${ }^{1}$ Cincinnatr Commercial, August 6th. 
Constitution that has not, within the last six years, been shamelessly and needlessly trampled under foot and that is not at this day yet more shamelessly and more needlessly violated." The radicals, he contended, had no respect for anything but their own ungoverned will and insatiate lust for power and plunder. "It was owing to the machinations of this faction that disunion and civil war were not peaceably averted; it was to their machinations that we owe the prolongation of the war two years longer than it would otherwise have lasted." This party was demanding that the white race, to whom the country owed everything, should become subordinate to the negro. "We have this proposition before us in Ohio, to confer the vote on seven or eight thousand blacks and mulattoes and to take it away from about three times as many white soldiers." $\mathrm{He}$ did not believe the negro capable of self-government, and as a proof cited the evils of negro equality in Mexico and Jamaica. The serious financial burdens of the war were also discussed, especially the increased taxation resulting from the maintenance of the Freedmen's Bureau and military reconstruction. $^{1}$

This attack threw the Unionists on the defensive for a tims. ${ }^{2}$ With the burden resting upon them of showing that artial suffrage would be best for the country, they were called upon, as the campaign progressed, to defend selves against the charges of partisan violence, corrupin financial matters, and the selfish motive of conferring

cinnati Commercial, August 6th.

res was criticised by members of his party for taking the defensive. ver to a suggestion, he wrote, September Ist: "My own notion $t$ in replying to Thurman as I did I was making the Copperhead I main topic which I knew was our victory. But the form of 1ssion was as you say defensive. In deference to such criticism speat, I have changed all that and say the same things now in ssive form." MS. Letter. 
suffrage on the negro in order to maintain themselves in power. One of their strongest arguments was the inconsistency of forcing negro suffrage upon the South, and refusing to accept it at home. They became much confused in claiming that the right to vote was a natural right of which the colored people were being unjustly deprived. In urging the discarding of past issues and the discussion of those only with which the people must deal in the future, Vallandigham and Thurman laid themselves open to the charge that they were anxious to forget the past. To keep it before the people, the Unionists circulated throughout the state a pamphlet entitled "The War Record of the Ohio Democracy" made up of excerpts from Democratic speeches and platforms and newspaper articles of the war period. The people were thus called upon to decide between approving the past record of the Democrats and endorsing negro suffrage.

The campaign aroused a national interest little less intense than that of 1863 . The leaders on the Democratic side were of course Thurman, Vallandigham and Pendleton, ably assisted by Ranney, Jewett, General Durbin Ward, and many others of lesser prominence. Voorhees came in from Indiana for a few speeches, but for the most part the Democrats of the state conducted their own fight. The Unionists, in addition to their own leaders, Hayes, Sherman, Wade, Tod, Dennison and Cox, enlisted many speakers from abroad. Morton, Julian, Colfax, General Washburn, and Governor Baker came from Indiana; John A. Logan, from Illinois; Senator Chandler, from Michigan; and Governor Harriman, from New Hampshire.

During the course of the contest, Wade made two speeches in the southern part of the state, one at Marietta and the other at Portsmouth, in which he entered into a most virulent tirade against the Democracy. The party, he said, was 
not only dead but damned through the sin of treason. They had put in nomination in 1863 a traitor-one who had been convicted of treason and who ought to have been hung. Their opposition to negro suffrage was all an appeal to prejudice; they considered the negro too ignorant to vote, but they could not make intelligence a test, because that would disfranchise three-fourths of the men who carried the elections in the Democratic city of New York. Did anyone, he asked, ever know a negro who was a traitor; did anyone ever know a Democrat who was not a traitor in practice whatever he might have thought about it? ${ }^{1}$ This was too much for the conservatives of the southern counties, and did much to injure the Union party in that section. As the Cincinnati Commercial expressed it: "His unmeasured, if not inconsiderate, vituperation is ill calculated to serve a good cause."

Both parties made an exhaustive canvass of the state, the opposing candidates for gcvernor speaking in nearly every county. The meetings were largely attended and enthusiastic, in numbers, falling little short of those of the campaign of 1863 . Conspicuous in the Democratic processions were wagons filled with young girls, dressed in white, carrying banners inscribed with the appeal: "Fathers, save us from negro equality." The principal contest was made on the legislative ticket, and in the interest of his candidacy for the Senate, Vallandigham made a vigorous effort to secure election of a majority of Democratic members. sughout the campaign, General Hayes conducted himin a dignified manner, making no effort to dodge the ige question, but arguing on the ground of justice, for franchisement of the colored man.

The result of the election showed in no uncertain way

${ }^{1}$ Cincinnati Commercial, August 26th. 
the attitude of the people of the state on the question at issue. With an increase in the total vote over the election of I865 of 67,000 , Hayes' majority was only 2,983 . The vote on the Amendment was 12,000 less than that for governor, and the direct majority against it was 38,000 . Considering those not voting as being against it, the majority was 50,000. Even the Reserve, which gave Hayes a majority of 21,000 , gave 5,000 less for the amendment. The Democrats carried both branches of the legislature.

There were many charges of negro voting in several parts of the state, particularly in Greene and Fayette counties and on the Reserve. The Democratic press estimated that no less than three thousand mulattoes and negroes had voted in the election. Regarding the cause of the defeat, there was much difference of opinion among the Unionists. The disfranchising clause, the strong argument of the Democrats against the heavy taxation caused by the reconstruction measures, the proposition to pay the bonds of the United States in greenbacks which Pendleton injected into the campaign, and the violence of Senator Wade in his speeches, were all given as reasons. There was no possibility of denying that the amendment had been defeated by direct negative votes, and not by the failure of any considerable number of people to cast a ballot on the subject. To the Democrats, the election meant a distinct repudiation of the proposition of negro suffrage in all its aspects, and it was on this interpretation that they proceeded to undo all the work of the Unionists directed toward it.

On the first day of the session of the new legislature in January, I868, joint resolutions were introduced in both branches for rescinding the ratification of the Fourteenth Amendment which was still before the states. The House resolution gave as reasons for this action, that the provisions of the Amendment were $\epsilon x$ post facto, and would confer 


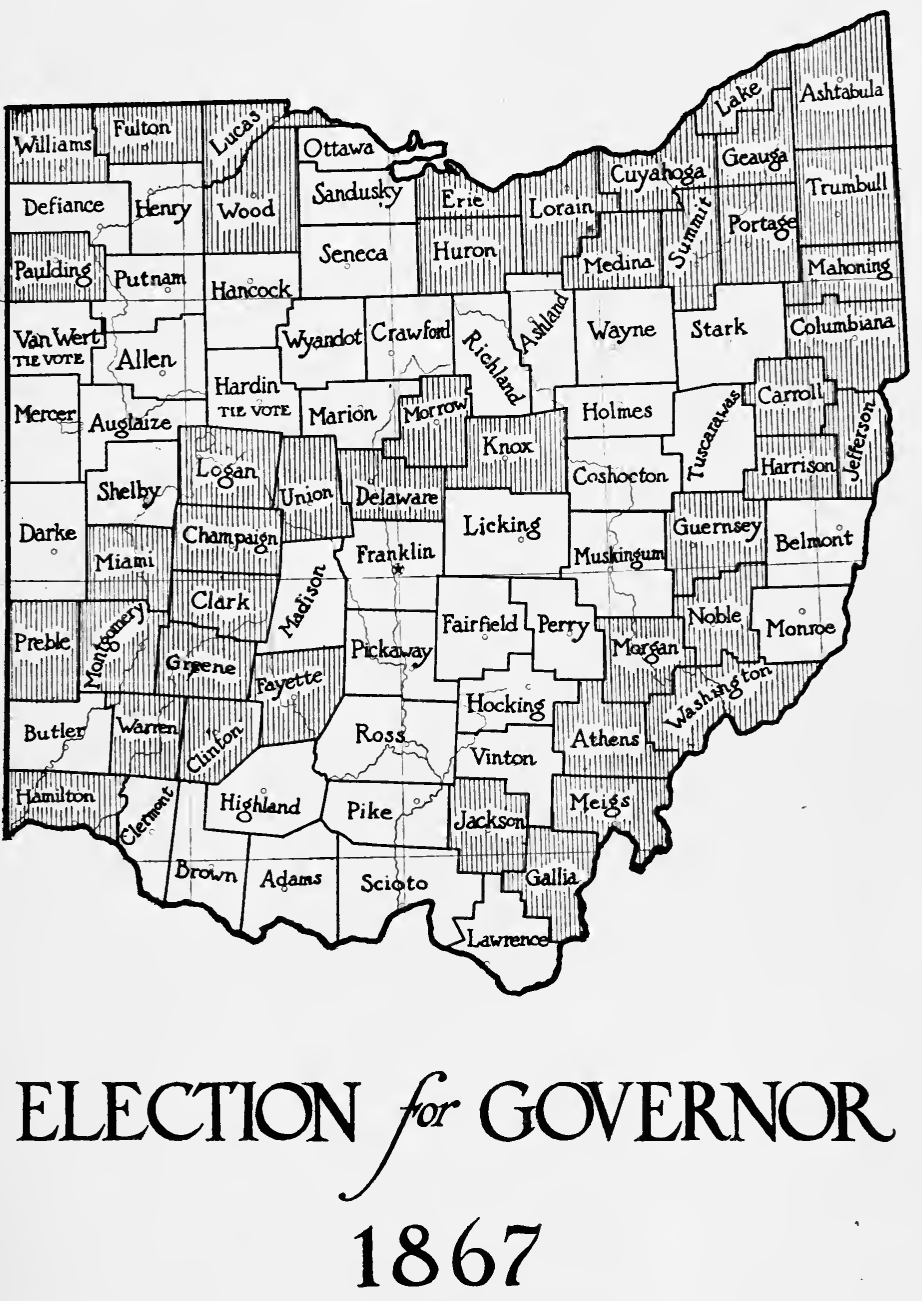

\author{
Unionist Counties Shaded \\ Democratic Counties Unshaded
}



upon Congress power to legislate on subjects foreign to the original objects of the Federal compact; that it would enforce negro suffrage and negro political equality in the state; and that it was a misrepresentation of the public sentiment of the people of Ohio and contrary to the best interests of the white race. It requested the President to cause to be returned to the governor all papers on file in the Executive Department certifying the ratification by the state legislature. $^{1}$ The Senate resolution recited in the preamble the right of each state to withdraw its assent to any proposed amendment at any time before ratification by three-fourths of the states should have been completed, and provided that copies of the rescinding resolution be sent to the President, to the Senators and Representatives from Ohio, and to the governors of all the states, and that the President and the presiding officers of both branches of Congress be requested to return all papers certifying the ratification of the Amendment. $^{2}$ It was practically in this form that the resolution passed both houses, January 15 th ${ }^{3}$ the Senate hurrying it through, under the previous question, with such haste that a protest was registered by the Union senators. ${ }^{4}$ The Democrats justified their action on the ground that the Unionists were attempting to postpone a vote until Congress had declared the Amendment part of the Constitution.

Some delay was experienced in getting the resolution forwarded. A week after it had been adopted, it was found that the governor had done nothing in the matter, and a te of inquiry was sent to him asking the cause. Hayes lained the delay by saying that the resolution did not ex-

'ouse Journal, 1868, p. 10.

nate Journal, r868, p. 7.

ws of Ohio, vol. 1xv, p. 280.

o State Journal, January 15 th. 
pressly request the governor to transmit it, and hence the secretary of state did not deem it his duty to send copies to the executive office for transmission. A further resolution was then adopted specifically requesting that copies be sent. ${ }^{1}$ A reply was received from Secretary of State Seward stating that there was no law permitting him to withdraw any document committed to the Department either at the request of an individual or a state. The resolution ratifying the Amendment and that rescinding it would remain in the files of the Department, he said, "and have such effect as they may respectively be entitled to." ${ }^{2}$

For their action the Democrats had two arguments of considerable weight. In the first place the Unionists had set a precedent in rescinding the ratification of the Corwin Amendment of $1864,{ }^{3}$ and secondly the rejection of the amendment to the state Constitution in the election furnished conclusive proof that the people of the state were opposed to the principle of negro suffrage. The rescinding resolution went for nothing, however, as did a similar one adopted by the New Jersey legislature. In his first certificate of ratification, July 20, I868, Secretary Seward stated that if the ratifying resolutions of Ohio and New Jersey were to be considered as remaining in full force, then the Amendment had been ratified by the requisite number of states. ${ }^{4}$ On the next day a concurrent resolution was passed by Congress declaring the Amendment to be part of the Constitution, the two states being counted among those

${ }^{1}$ Laws of Ohio, vol. 1xv, p. 283.

${ }^{2}$ Plain Dealer, February I3th. For a discussion of the action of the various states on the Amendment, see Flack, Adoption of the Fourteenth Amendment, chapter iv.

${ }^{3}$ Cf. supra, p. 122.

${ }^{4} \mathrm{McPherson}$, History of Reconstruction, p. 379. 
having ratified it. ${ }^{1}$ In accordance with this action, the Secretary issued a final proclamation on July 28 th, declaring the Amendment duly ratified by three-fourths of the states and a part of the fundamental law. ${ }^{2}$

The charges of illegal voting at the election of 1867 were taken up for investigation by the new legislature, and measures were adopted to prevent its repetition in the future. In the eighth senatorial district ${ }^{3}$ where the election was contested, the Democratic candidate claimed that forty-two votes were cast by persons "having a distinct and visible mixture of African blood." The Senate committee on elections in awarding the seat to him held that "the word white means pure white, unmixed, and, in the language of the Constitution and in popular language, excludes the whole African race, whatever may be the admixture of African blood." " For the first time in a decade it was possible again to give this interpretation the authority of legislative expression, and following the committee's report, a bill was introduced in the Senate providing for the reënacting of the "Visible Admixture law." After having been amended in several particulars, it was passed toward the close of the session. It required the challenging of any person offering to vote at any election whenever it should appear to the judges that the person had a distinct and visible adT xture of African blood. Anyone so challenged must er under oath as to his age, place of birth, whether $t$ his parents were married and if either of them had a st and visible admixture of African blood, whether he was classified as a colored person in his commuind if his children attended the schools for colored

herson, History of Reconstruction, p. 380.

${ }^{2}$ Ibid., p. 417. ence, Gallia, Meigs and Vinton counties.

- Journal, I868, App., p. 16. 
or white children, and must produce two reliable witnesses to swear to the truth of his statements. If the questions were all answered satisfactorily, the person was to swear that to the best of his knowledge he was a white person, thereupon his vote was to be taken, and the clause "challenged on the ground of visible admixture of African blood" entered on the poll book opposite his name. Safeguards were provided for the proper enforcement of the act by prescribing heavy penalties for false swearing, for receiving any illegal vote and for improper challenging. Finally, the act was to be given in special charge to the grand jury at each term of the court of common pleas. ${ }^{1}$

A supplementary act passed the next day in amendment of the general election law provided penalties against judges for refusing to receive a ballot from any person known to have the qualifications of ar elector, but exempting from its provisions judges who refused to receive the votes of persons having a visible admixture of African blood and freeing them from any liability for damages by reason of such rejection. ${ }^{2}$

The radical advocates of negro suffrage at once began a campaign of opposition to these measures. In Summit county, the judge in charging the jury held that the laws were unconstitutional and not to be regarded. This led to the adoption of a resolution by the House that the judiciary committee should inquire into the facts and report at an early date whether the judge should not be impeached for high crimes and misdemeanors. ${ }^{3}$ In Greene county a case was promptly brought against the election judges for refusing to receive the vote of a mulatto at a local election. It went up to the Supreme Court, which was still controlled

'Laws of Ohio, vol. lxv, p. 97.

${ }^{2}$ Ibid., p. 100.

${ }^{3}$ House Journal, i868, pp. 981 and 1050. 
by the friends of negro suffrage, and both acts were declared unconstitutional. ${ }^{1}$ The matter was thus reduced to the same situation in which it was placed in 1860 , when the first "Visible Admixture law" was held to be unconstitutional.

In addition to dealing with the subject of negro suffrage, this legislature, at its first session, had the privilege of selecting a United States Senator to succeed Wade. A spirited contest for the place began immediately after the election of 1867 between Vallandigham and Thurman. According to the pre-convention agreement, it rightfully belonged to the former, but the latter's friends held that his brilliant canvass against Hayes and the negro-suffrage amendment entitled him to some recompense. Both candidates urged their claims in speeches throughout the state, and the contest was not ended until January 13 th when in a Democratic caucus Thurman received fifty-one votes to his opponent's twenty-four. Vallandighain worked almost single-handed with the Democratic members of the legislature during the days preceding the caucus; he was deserted. however, not only by many of his hitherto strong supporters, but also by several of those who had actually pledged themselves to him during the campaign. Jealousy of the leaders and the fear lest, should he be chosen, he would not be admitted by tine Senate, seemed to be the prinin al reasons for this desertion. To Vallandigham, the eat meant the blasting of his highest hopes-a seat in United States Senate-and caused his temporary retirement from politics.

the next session when the Fifteenth Amendment was ved, a resolution was passed, May $4^{\text {th }}$, rejecting it. ${ }^{2}$ governor delayed sending this to the Secretary of State

lins vs. Monroe, 17 Ohio State Reports, p. 665.

is of Ohio, vol. Ixvi, p. 424. 
until the latter part of August, and during the summer Ohio was listed as one of the states which had not acted on the Amendment. In the fall of 1869 , fusion tickets were put in the field by the Democrats and conservatives of the opposite party in many of the counties on a platform of reform in local affairs. In Hamilton county such a fusion ticket was nominated not only for the local offices but also for the legislature; it was understood by the Democrats that the conservatives would stand with them in matters coming before the two houses. This ticket was successful, and the members so elected, held the balance of power in the legislature. On a resolution to ratify the Fifteenth Amendment the conservatives voted for it, thus securing its adoption by a majority of one vote in each House. By this narrow margin Ohio, after a contest lasting over five years, gave her voice for negro suffrage. In the new Constitution drafted by the constitutional convention of 1873 , the word "white" was omitted from the article prescribing the qualifications for the elective franchise, but as this document was not accepted by the people, the word still ${ }^{1}$ remains in the fundamental law, though its effect was rendered void by the Fifteenth Amendment.

${ }^{1}$ Written in 1911 . 


\section{BIBLIOGRAPHICAL NOTE}

The political history of Ohio during the Civil War period has not received a satisfactory treatment in any of the secondary works on the history of the state. Whitelaw Reid, Ohio in the War (Cincinnati, I868), contains a brief account covering the years I860 to I865. Rufus King, Ohio (Boston, I903), gives one chapter to the military and political events of the period. Most of the other histories deal exclusively with the military side. S. S. Cox, Three Decades of Federal Legislation (Providence, I885), gives the attitude of the Democrats on many questions of the times. James Ford Rhodes, History of the United States (New York, 1893 to 1906), treats the political affairs of the state which came prominently into national politics.

A critical bibliography of all material printed in book or pamphlet form has been compiled by Daniel J. Ryan under the title, The Civil War Literature of Ohio (Cleveland, I9I I). This work will be an invaluable aid to future students of the period. A list of Ohio newspapers and periodicals which have been preserved in the various libraries of the state and elsewhere has been compiled by C. B. Galbreath, Librarian of the Ohio State Library (Columbus. In? ).

are several unpublished collections of letters in the of Congress, notably the papers of Salmon P. ndrew Johnson and Governor William Allen, which nuch information on Ohio politics. In addition to Se of these, the author has been able to examine
s. $\mathrm{F}$ 



\section{VITA}

George Henry Porter was born at Port Washington, Ohio, October 8, i878. He was graduated from the New Philadelphia, Ohio, high school in 1895 and from the Ohio State University in I90I. He attended the University of Chicago during the summer quarters of 1904-5-6. From I907 to I9Io he was a graduate student at Columbia University, where he attended courses given by Professors Burgess, Dunning, Osgood, Shepherd and Goodnow. During the year 1908-I909 he held a University Fellowship in American History. 






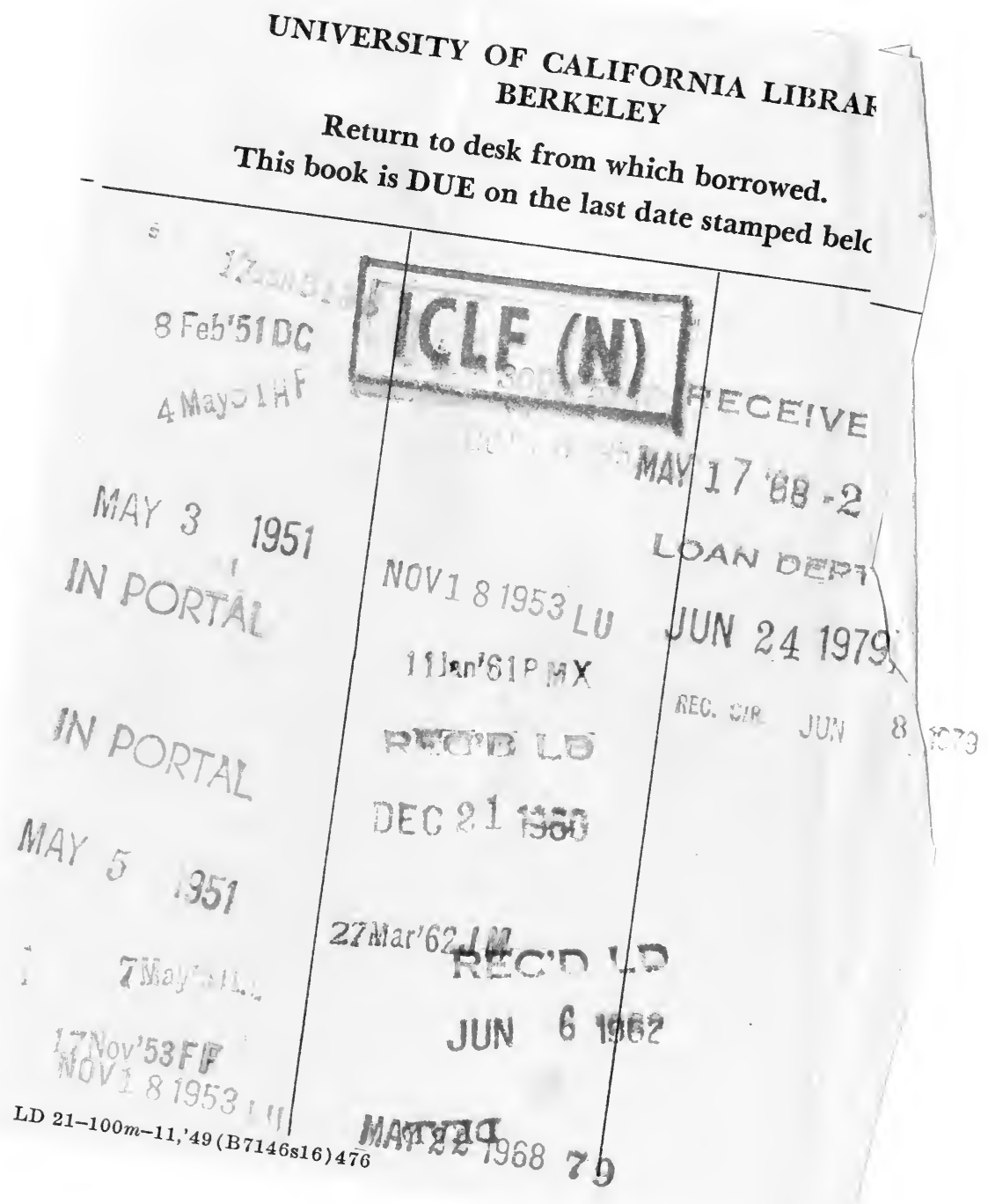


YC 0917ó

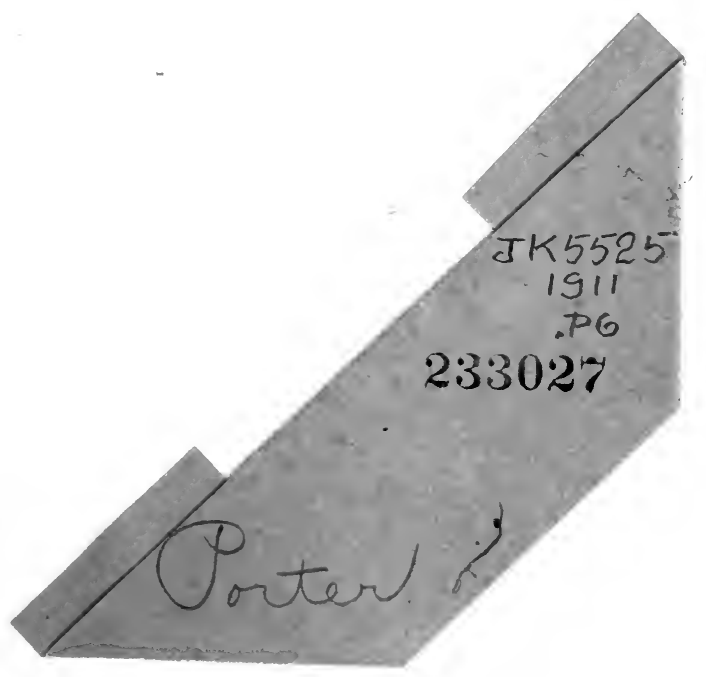

$\cdots:$ 
